Pacific Northwest National Laboratory

Operated by Battelle for the U.S. Department of Energy

\title{
Groundwater Monitoring Plan for the 216-S-10 Pond and Ditch
}

\author{
B. A. Williams \\ C. J. Chou
}

October 2002

Prepared for the U.S. Department of Energy under Contract DE-AC06-76RL01830 


\title{
DISCLAIMER
}

This report was prepared as an account of work sponsored by an agency of the United States Government. Reference herein to any specific commercial product, process, or service by trade name, trademark, manufacturer, or otherwise does not necessarily constitute or imply its endorsement, recommendation, or favoring by the United States Government or any agency thereof, or Battelle Memorial Institute.

\section{PACIFIC NORTHWEST NATIONAL LABORATORY \\ operated by \\ BATTELLE \\ for the \\ UNITED STATES DEPARTMENT OF ENERGY \\ under Contract DE-AC06-76RL01830}

Printed in the United States of America

Available to DOE and DOE contractors from the

Office of Scientific and Technical Information, P.O. Box 62, Oak Ridge, TN 37831;

prices available from (615) 576-8401.

\begin{abstract}
Available to the public from the National Technical Information Service, U.S. Department of Commerce, 5285 Port Royal Rd., Springfield, VA 22161
\end{abstract}

This document was printed on recycled paper. 


\title{
Groundwater Monitoring Plan for the 216-S-10 Pond and Ditch
}

\author{
B. A. Williams \\ C. J. Chou
}

October 2002

Prepared for

the U.S. Department of Energy

under Contract DE-AC06-76RL01830

Pacific Northwest National Laboratory

Richland, Washington 99352 


\section{Summary}

This monitoring plan establishes a groundwater monitoring plan for the $216-\mathrm{S}-10$ pond and ditch and supersedes the original monitoring plan by Airhart et al. (1990). This Resource Conservation and Recovery Act (RCRA) plan complies with the requirements of 40 CFR 265, Subpart F, and WAC 173-303-400. The site is part of the Comprehensive Environmental Response, Compensation, and Liability Act (CERCLA) 200-UP-1 Operable Unit. The 216-S-10 pond and ditch has not received waste since October 1991 and is scheduled for closure under a Part B Permit and in accordance with a record of decision after 2006 as determined in the Tri-Party Agreement.

This plan provides the U.S. Department of Energy with a revised detection monitoring well network and updates the list of constituents based on the knowledge gained from monitoring data collected over the years. The plan also provides the current interpretation of the site hydrogeology, groundwater flow, and potential for contamination. It also discusses recent and future reductions in the groundwater well network that may be necessary due to the declining water table and sitewide funding priorities. This plan is an integrated approach that uses CERCLA resources to fulfill RCRA (and future CERCLA) groundwater monitoring requirements. The monitoring network for the $216-\mathrm{S}-10$ pond and ditch includes the wells described in Table S.1.

Groundwater monitoring constituents include

- RCRA indicator parameters (specific conductance, $\mathrm{pH}$, total organic carbon, total organic halides as required by 40 CFR 265.92 (b)(2)) for statistical analysis

- Site-specific parameters (chromium, carbon tetrachloride, vanadium, and chloroform) identified during evaluation of historical groundwater data results

- Groundwater quality parameters (as required by 40 CFR 265.92 (b)(3))

- Other (field) parameters include alkalinity, temperature, and turbidity.

Table S.1. Proposed Monitoring Wells at the 216-S-10 Pond and Ditch

\begin{tabular}{||l|l|l||}
\hline \multicolumn{1}{|c|}{ Well Number } & \multicolumn{1}{c||}{ Purpose } & \multicolumn{1}{c||}{ Comments } \\
\hline \hline $299-W 26-7$ & RCRA upgradient & Going dry; will be deepened* \\
\hline 299-W26-12 & RCRA downgradient & Dry; will be deepened* \\
\hline 299-W26-13 & CERCLA characterization/RCRA downgradient & Installed in 1999 \\
\hline New Well & CERCLA characterization/RCRA downgradient & To be drilled in 2003 \\
\hline 299-W27-2 & Deep/bottom of aquifer & Supplemental data \\
\hline *Deepening depends on the results of a technology demonstration occurring in FY2003. \\
\hline
\end{tabular}

The averaged replicate t-test method is used to determine if the facility has adversely impacted groundwater quality (in accordance with 40 CFR 265.92). 


\section{Contents}

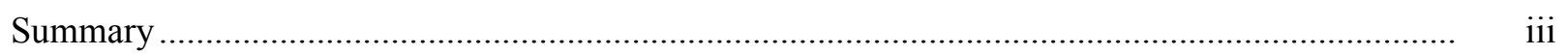

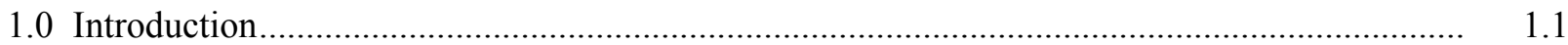

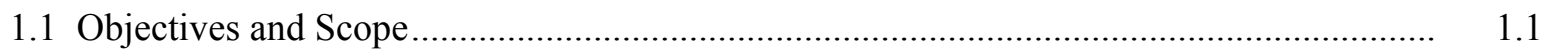

1.2 Regulatory Status and History …………………………………………………….. 1.1

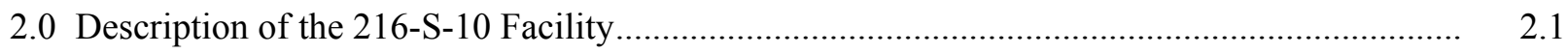

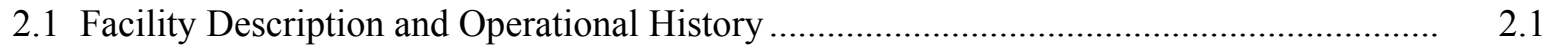

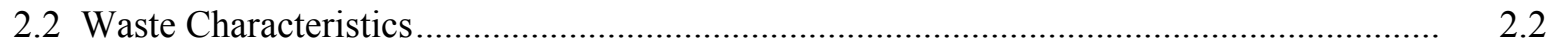

2.3 Soil Contamination Characterization Activities ................................................................ 2.4

2.4 Constituents of Concern............................................................................................. 2.5

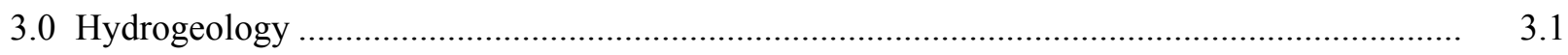

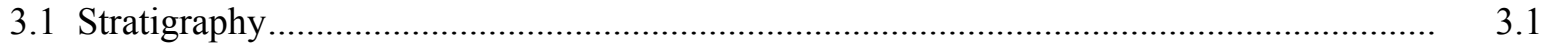

3.1.1 Ringold Formation (Units 4 through 9) .................................................................... 3.7

3.1.2 Plio-Pleistocene Unit (Units 2 and 3) ……………............................................ 3.7

3.1.3 Hanford Formation (Unit 1) ............................................................................ 3.8

3.2 Physical Hydrogeology ......................................................................................... 3.8

4.0 Summary of Groundwater Monitoring Results .................................................................. 4.1

4.1 Contamination Indicator Parameters............................................................................... 4.1

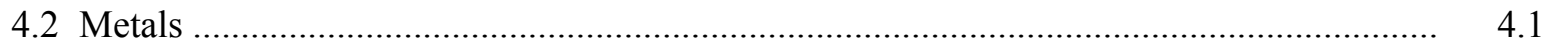

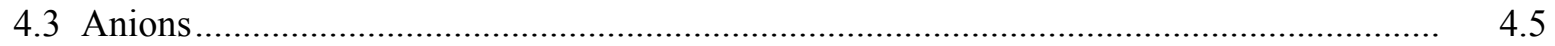

4.4 Exceedances of Maximum Contaminant Level ...................................................................

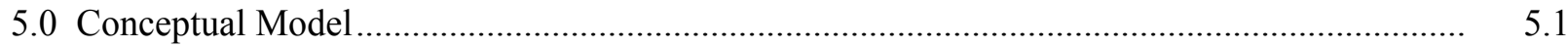




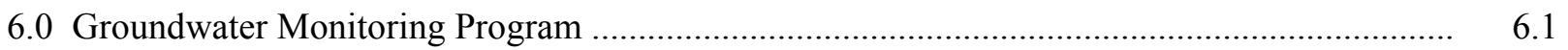

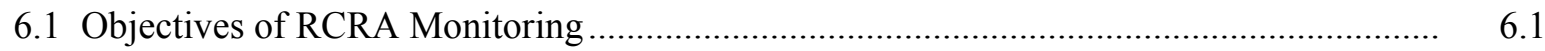

6.2 Special Conditions at the S-10 Pond and Ditch ..................................................... 6.1

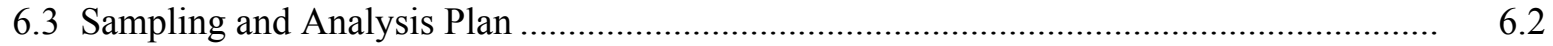

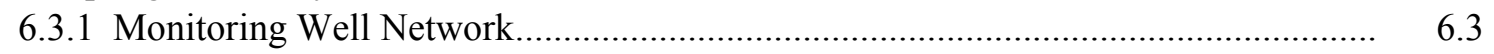

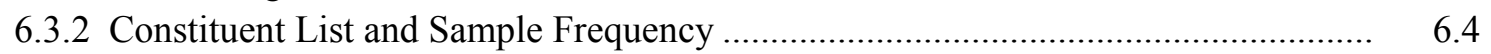

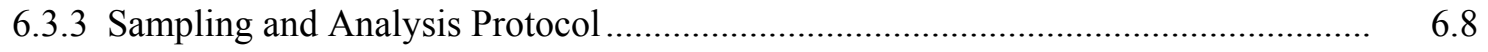

6.3.4 Quality Assurance and Quality Control ................................................................. 6.9

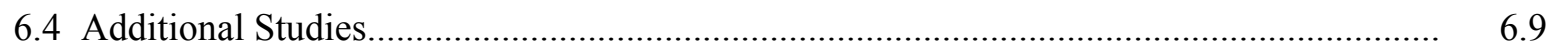

7.0 Data Management, Evaluation, and Reporting ........................................................

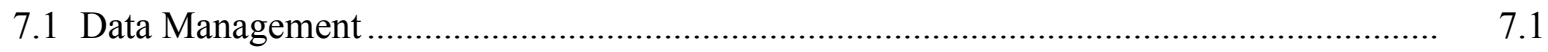

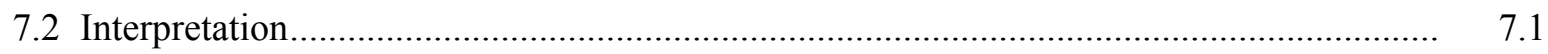

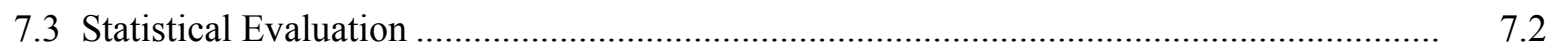

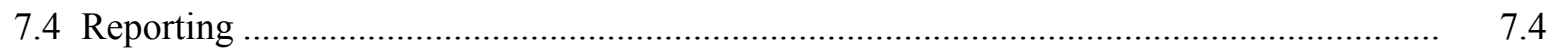

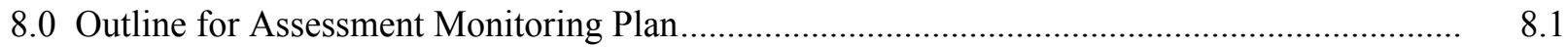

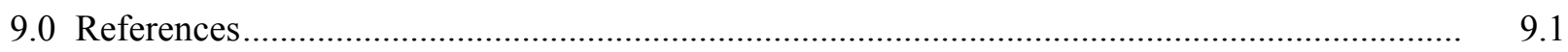

Appendix - Well Construction and Completion Summaries ...................................................... A.1 


\section{Figures}

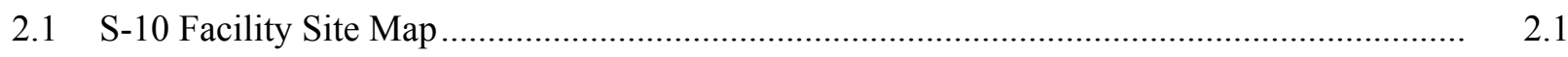

2.2 Timeline of Significant Events During Operation of the S-10 Facility ................................. 2.3

2.3 Effluent Volume Discharged to the 216-S-10 Ditch (216-S-10D), 216-S-10 Pond,

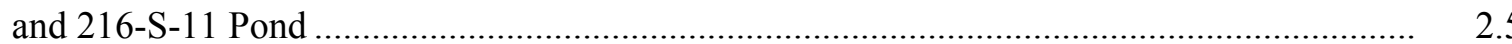

3.1 Topographic Illustration of Pleistocene Flood Channels and the Present-Day Columbia River Channel Pathways, with Outlines of the 200 West and East Areas,

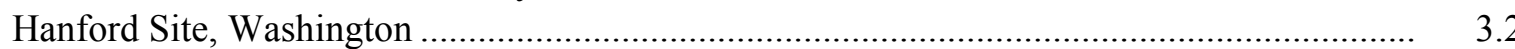

3.2 Comparison of Hydrogeologic and Geologic Classifications............................................. 3.3

3.3 Hydrogeologic South-North Cross Section in the 200 West Area and Near S-10 Facility ...... $\quad 3.4$

3.4 Hydrogeologic East-West Cross Section in the 200 West Area and Near S-10 Facility.......... 3.4

3.5 Detailed Hydrogeologic Cross Section at the S-10 Facility ............................................... 3.5

3.6 Hydrographs of Wells Monitoring the S-10 Facility …..................................................... 3.9

4.1 Chromium Concentrations Versus Time …....................................................................

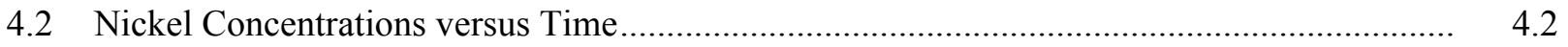

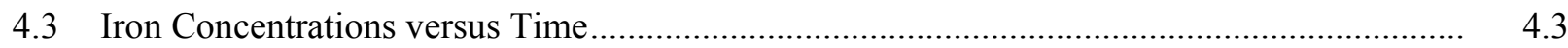

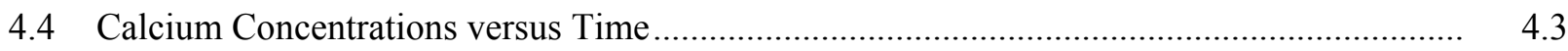

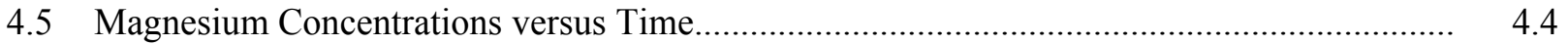

4.6 Manganese Concentrations versus Time ....................................................................

4.7 Sodium Concentrations versus Time ........................................................................... 4.5

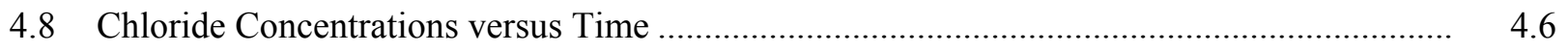

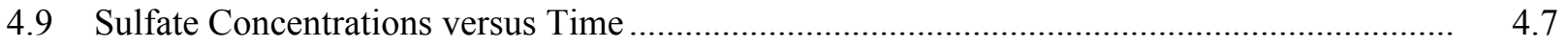

4.10 Nitrate Concentrations versus Time …................................................................ 4.7 
4.11 Chromium and Nitrate Concentrations in Well 299-W26-7 ...............................................

4.12 Chromium and Nitrate Concentrations in Well 299-W26-10 ............................................ 4.8

4.13 Chromium and Nitrate Concentrations in Well 299-W26-12 ..........................................

4.14 Chromium and Nitrate Concentrations in Well 299-W26-9 ................................................

5.1 Conceptual Model of Infiltration of Effluent at the 216-S-10 Facility .............................. 5.3

6.1 Well Location Map at the 216-S-10 Pond and Ditch ............................................................

\section{Tables}

S.1 Proposed Monitoring Wells at the 216-S-10 Pond and Ditch ........................................... iii

2.1 Composition of Synthetic Double-Shell-Tank Slurry ...................................................... 2.4

3.1 Hydraulic Conductivities for Major Hydrogeologic Units .............................................. 3.9

6.1 Revised Monitoring Wells for the 216-S-10 Ditch and Pond ............................................. 6.3

6.2 Detection Status of Final List of Potential Contaminants of Concern at the

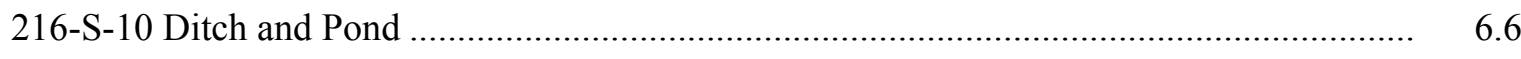

6.3 Maximum Values and Hanford Site Groundwater Background Values for Detected Analytes at the 216-S-10 Pond and Ditch.................................................................................

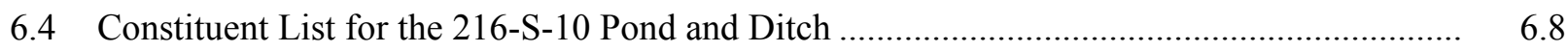

7.1 Critical Means for 216-S-10 Pond and Ditch for FY2002 Comparisons ............................

8.1 Groundwater Quality Assessment Plan Outline ...................................................... 8.1 


\subsection{Introduction}

This document presents an updated and revised Resource Conservation and Recovery Act (RCRA) groundwater monitoring plan for the 216-S-10 pond and ditch (S-10 facility), located south-southwest of the 200 West Area on the Hanford Site in Washington State. RCRA groundwater monitoring has been conducted in accordance with interim status requirements [40 CFR Part 265, Subpart F, which is incorporated into Washington State Department of Ecology (Ecology) regulations (WAC 173-303-400) by reference] since 1991 . The S-10 facility is currently monitored under indicator evaluation program status as described in Airhart et al. (1990). The site is also within the 200-UP-1 Operable Unit of the Comprehensive Environmental Response, Compensation, and Liability Act (CERCLA). The S-10 facility has not received liquid waste since October 1991 and is scheduled to be closed under a Part B Permit after 2006 in accordance with the Tri-Party Agreement (Ecology et al. 1998) Permit modification schedule.

The plan presented here proposes a revised well network and updates the list of constituents based on the knowledge gained from monitoring data collected over the past eleven (11) years for this site. It also provides the current interpretation of groundwater flow and potential for contamination occurrence. Additionally, a conceptual model of contaminant transport through the vadose zone beneath the S-10 facility is presented in this plan to assist in developing appropriate and cost effective monitoring for this facility.

\subsection{Objectives and Scope}

The purpose of this plan is to establish a groundwater monitoring program for the S-10 facility that will address recent and future reductions in the monitoring network due to declining water table and funding priority in drilling new wells on the Hanford Site. The plan incorporates the sum of knowledge about the potential for groundwater contamination to originate from the S-10 facility. This document also summarizes past and current groundwater monitoring results at the S-10 facility and presents a conceptual model derived from the hydrogeology, operational history, and the conditions of the site. The updated plan presents an integrated monitoring approach that incorporates monitoring that may be required under a CERCLA Remedial Investigation/Feasibility Study (RI/FS) being conducted at the facility in accordance with the 200-CS-1 Operable Unit RI/FS Workplan (DOE/RL 2000). This groundwater monitoring plan supersedes the original plan (Airhart et al. 1990).

\subsection{Regulatory Status and History}

The S-10 facility has been regulated by the Washington Administrative Code (WAC) 173-303-400 and has been monitored under a RCRA interim status groundwater monitoring program since 1991 (Airhart et al. 1990). The RCRA Part A Permit application for this facility was submitted to Ecology on June 30, 1994, and subsequently approved by Ecology on October 30, 2000. RCRA groundwater monitoring at the S-10 facility was required because regulated waste from synthetic double-shell tank 
slurry was discharged to the site in 1983 . The chemical compounds comprising the slurry are those identified in the Part A Permit; they are ignitability (D001), corrosivity (D002), chromium (D007), and toxic waste (WT01, WT02).

The S-10 facility is also within the boundary of the CERCLA 200-UP-1 Operable Unit, which has the responsibility for cleanup activities at the waste sites within the operable unit. The Tri-Party Agreement requires that characterization and remediation of waste sites integrate the requirements of CERCLA and RCRA and provide a consistent, standard approach to cleanup activities to assure that applicable regulatory requirements are met. The 200 Areas Implementation Plan (DOE/RL 1999) outlines a framework to provide for consistent, integrated cleanup actions (i.e., characterization and remediation) in the 200 Areas and integrates the requirements of RCRA and CERCLA into one standard approach for cleanup activities.

Besides the ongoing RCRA interim status groundwater monitoring, the $\mathrm{S}-10$ facility has been defined, based on waste stream groupings, as part of the CERCLA 200-CS-1 chemical sewer group of waste sites. It will undergo a CERCLA RI/FS in accordance with the 200-CS-1 RI/FS work plan (DOE/RL 2000). These studies are being conducted to evaluate the potential for residual contaminants at the facility and to support the completion of a record of decision. The schedule for cleanup work at the Hanford Site is governed by Tri-Party Agreement milestones. The milestone controlling the schedule for the 200-CS-1 is milestone M-13-21, Submit Chemical Sewer Group Work Plan (August 31, 1999). In accordance with milestone M-15-00C, all characterization work in the 200 Areas is to be completed by December 31, 2008. An associated milestone is milestone M-20-39C, which requires submittal of the 216-S-10 pond and ditch closure/post-closure plans to Ecology by November 30, 2005. Milestone M-20-00B, Submit Part B Permit Applications or Closure/Post-Closure Plans for All RCRA TSD Units, requires permit applications, closure, and post-closure plans to be submitted to Ecology for approval by December 31, 2008.

The facility is no longer operational, and will be closed as a disposal facility under the RCRA Part B Permit in 2006 and in accordance with a CERCLA record of decision. 


\subsection{Description of the 216-S-10 Facility}

The information contained in this section came from three primary sources: Waste Information Data System (WIDS) General Summary Reports, Maxfield (1979), and DOE (1987). The WIDS database is maintained and controlled by Fluor Hanford, Inc.

\subsection{Facility Description and Operational History}

The S-10 facility is located south-southwest of the 200 West Area, directly outside the perimeter fence (Figure 2.1). Initially the S-10 facility consisted of an open, unlined ditch (216-S-10 ditch) that

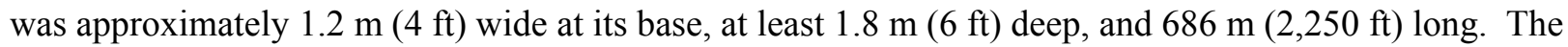
ditch received wastewater via pipeline from the Reduction-Oxidation (REDOX) facility in August 1951. The 216-S-10 pond (S-10 pond) was added to the southwest end of the S-10 facility in 1954; it covered $20,234 \mathrm{~m}^{2}(\sim 5$ acres) and included four finger-like leaching trenches when it was active. The pond was approximately $2.4 \mathrm{~m}(8 \mathrm{ft})$ deep at its deepest point. Like the ditch, the pond was unlined and, therefore, served as a percolation basin for liquid discharges. Water discharged into the ditch also flowed into the S-10 pond and infiltrated into the ground, which created perched water in the vadose zone and artificially recharged the underlying aquifer.

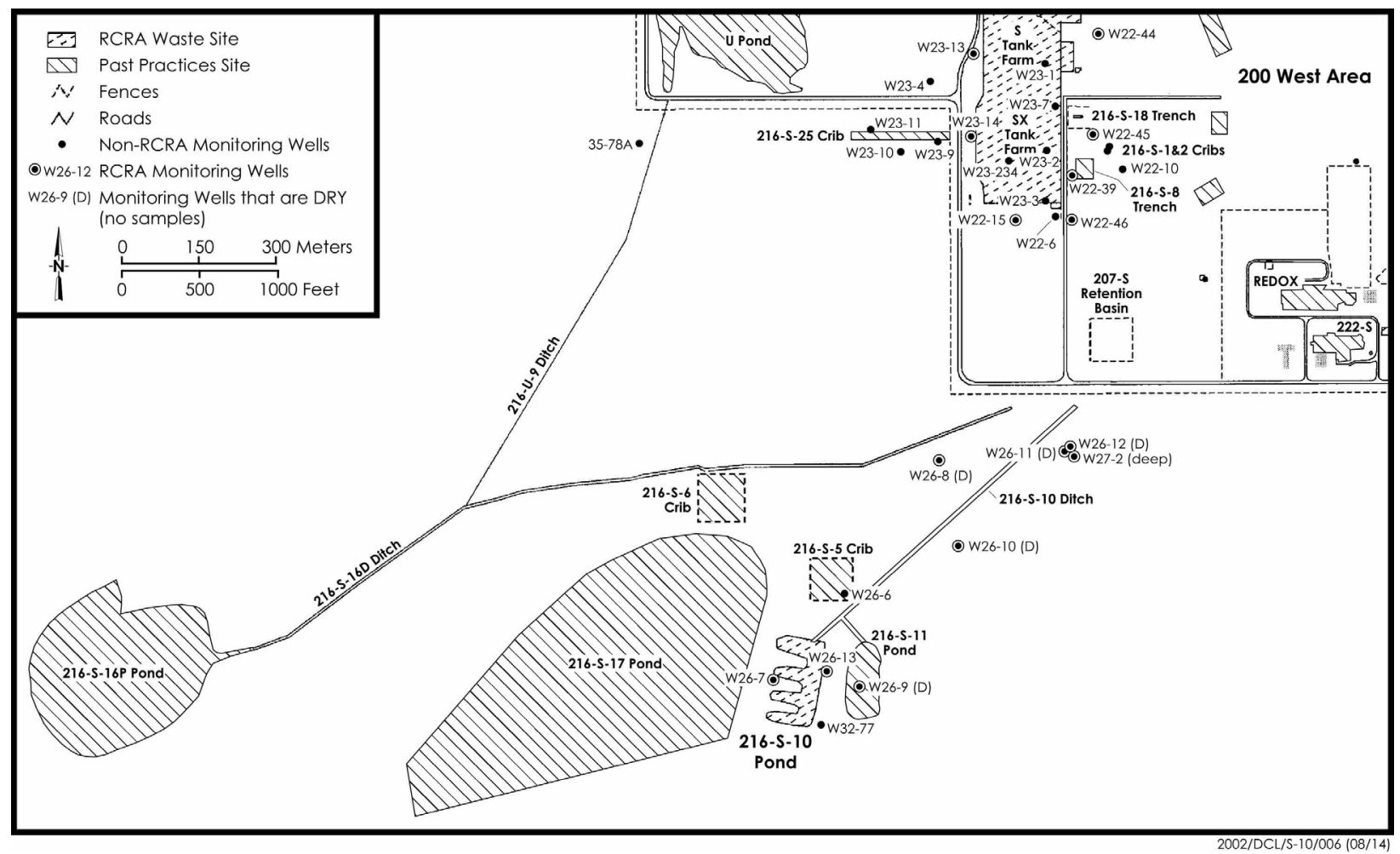

Figure 2.1. S-10 Facility Site Map 
As is evident from the site map (see Figure 2.1), there are a number of other waste disposal facilities that include cribs 216-S-5 and 216-S-6; ponds 216-U-10, 216-S-11 and 216-S-17; and pond and ditches 216-S-16 in the vicinity of the S-10 facility. The WIDS General Summary Reports for theses facilities are provided in Airhart et al. (1990, Appendix A). These summary reports give general facility descriptions, including descriptions of the site and the waste it received. It is important to note that effects from these sites on groundwater chemistry may in turn influence the groundwater chemistry near the S-10 facility. However, it is not possible to distinguish the possible offsite effects from that of the S-10 facility due to the lack of monitoring wells in the area. The following paragraphs describe the operational history of the S-10 facility.

In August 1951, the 216-S-10 ditch began receiving wastewater from the REDOX Plant chemical sewer. In February 1954, the 216-S-10 pond was dug at the southwest end of the ditch to provide more surface area for percolation. In May 1954, additional increases in discharge to the S-10 facility necessitated the digging of the two 216-S-11 leach ponds on the southeast side of the 216-S-10 ditch. An inadvertent release of ammonium nitrate non-hydrate reduced the infiltration capacity in the S-10 facility

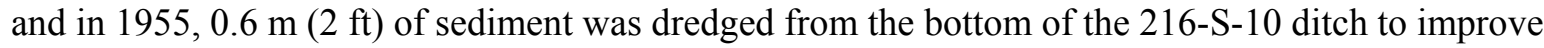
water percolation in the ditch. The contaminated sediment was buried in excavation pits along the sides of the ditch. The depth and location of the pits is unknown (RHO 1979). The 216-S-11 lobes were dammed in 1965, so that all of the effluent was diverted along the S-10 ditch to the $216-\mathrm{S}-10$ pond. The south lobe of the 216-S-11 pond was covered in the summer of 1975 and was free of radioactive contamination. The site as a whole was stabilized on September 30, 1983. The REDOX Plant was closed in 1967. At that time, effluent to the S-10 facility was reduced primarily to chemical sewer waste. When the REDOX Plant was deactivated in 1972, physical controls were administered to eliminate hazardous discharges from the REDOX Plant to the S-10 facility. These controls reduced discharges from the REDOX Plant to non-hazardous chemical sewer effluent.

In September 1983, the S-10 facility received a hazardous waste discharge from the Chemical Engineering Laboratory. This laboratory produced synthetic double-shell-tank slurry to test methods for recovering slurry from double-shell tanks (DOE 1987). The characteristics of the discharge from this facility are described in more detail in Section 2.2.

The 216-S-10 pond and southwest end of the 216-S-10 ditch were decommissioned, backfilled, and stabilized in October 1985; the northern portion of the ditch remained operational and received nonhazardous (i.e., not regulated under RCRA) chemical sewer waste from the REDOX Plant until October 1991 (BHI 1995). The effluent supply pipeline was plugged with concrete near the outfall in July 1994. The remaining portion of the S-10 ditch was decommissioned and backfilled in 1991. The sequence of important events surrounding operation of the S-10 facility is summarized in Figure 2.2.

\subsection{Waste Characteristics}

The following section was adapted from the 200-CS-1 Operable Unit RI/FS work plan and RCRA treatment, storage, and disposal unit sampling plan (DOE/RL 2000).

This section summarizes the chemical and physical characteristics of past discharges to the S-10 facility. Most of the liquid waste discharged to the S-10 facility came from the REDOX Plant's 


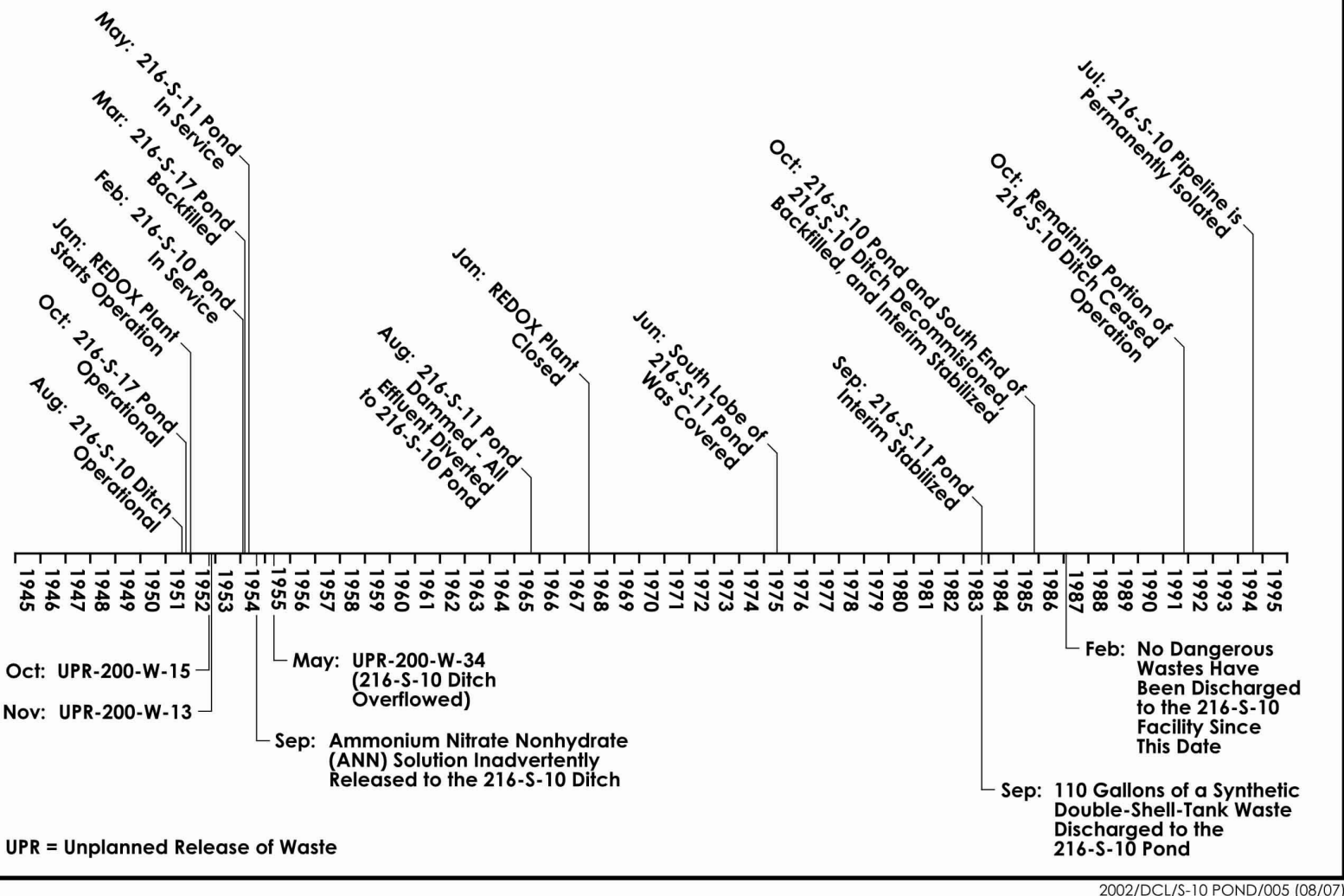

Figure 2.2. Timeline of Significant Events During Operation of the S-10 Facility

chemical sewer and the Chemical Engineering Laboratory. The chemical sewers were designed to be uncontaminated, but they often contained limited quantities of radionuclides and chemicals. Approximately 50 waste streams contributed to the $216-\mathrm{S}-10$ ditch (WHC 1990). The routine waste stream sources include the compressor cooling water from the REDOX Plant and the sanitary water overflow from the 2901-1-901 water tower. The remaining sources were infrequent additions and included waste from REDOX Plant floor drains and funnel drains; S tank farm pump drains, tank drains, station drains, chemical sewer line manholes; and 276-S Building floor drains.

Releases of hazardous constituents to the S-10 facility from 1951 to 1966 are poorly documented. An unspecified quantity of aluminum nitrate (i.e., non-regulated chemical waste) was discharged to the 216-S-10 ditch in 1954 (Maxfield 1979). In addition, Maxfield (1979) recorded that there was a problem of radioactivity (not regulated under RCRA) in the ditch from contaminated floor and sewer drains within

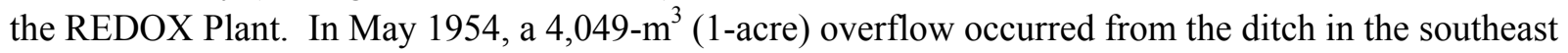
dike (earth fill) of the 216-S-11 pond (UPR-200-W-34) (GE 1956). A follow-up survey indicated the trench was contaminated up to a maximum of $800 \mathrm{mrads} / \mathrm{hr}$, at $500 \mathrm{mrem} / \mathrm{hr}$ in some areas with lower contamination, and up to 80,000 count per minute (cpm) in the overflow area. Some decontamination of the area occurred after the release. Records indicate that a considerable amount of surface contamination could be found along the ditch banks and the pond bottom (RHO 1979). 
In September 1983, a documented hazardous waste discharge to the S-10 facility occurred (DOE 1987). In this incident, $416.4 \mathrm{~L}$ (110 gal) of synthetic double-shell-tank slurry was discharged to the S-10 facility. The waste consisted largely of $\mathrm{NaNO}_{3}(46 \%)$ and $\mathrm{NaOH}(41 \%)$, with small quantities of $\mathrm{Na}_{3} \mathrm{PO}_{4}, \mathrm{NaF}, \mathrm{NaCl}$, and $\mathrm{K}_{2} \mathrm{Cr}_{2} \mathrm{O}_{7}$. Samples of this slurry taken from the two feed tanks, TK-505 and TK-509, before the discharge occurred were analyzed; the results of these analyses are presented in Table 2.1. The synthetic tank slurry is comprised of the chemical compounds identified in the Part A Permit application submitted for the 216-S-10 pond and ditch (see Section 1.2).

The portion of the 216-S-10 ditch that was still in service after 1985 received chemical sewer discharge from the REDOX Plant. The waste stream entered the north end of the ditch through a vitrified clay pipe $30.5 \mathrm{~cm}$ (12 in.) in diameter. This waste stream was composed of cooling water from waterscrubbed air-conditioning filters, air-conditioning bearings, and seal loops; overflow from the sanitarywater tower; steam condensate from building heaters and station steam supply; and floor-drain effluent produced by pipe leaks and pump overflow (DOE 1987). As part of deactivation of the REDOX Plant in 1972 , the source streams from the plant were routed so that they would not come into contact with hazardous materials. Combined cumulative liquid discharges of $6.6 \times 10^{9} \mathrm{~L}\left(1.7 \times 10^{9}\right.$ gallons $)$ went to the S-10 ditch and the S-11 pond.

During operations, the maximum volume of wastewater discharged daily to the $216-\mathrm{S}-10$ pond and ditch was approximately 568,000 L (150,000 gal) per day. The annual volume of effluent discharged was approximately $1.9 \times 10^{8} \mathrm{~L}\left(5.0 \times 10^{7} \mathrm{gal}\right)$. Standing water was present in the ditch and created conditions conducive for pond vegetation growth. Figure 2.3 illustrates the combined effluent volume discharged to the 216-S-10 ditch and 216-S-11 pond. Wastewater from the REDOX Plant has been combined with the 200 West portion of the effluent collection system for disposal since 1995.

\subsection{Soil Contamination Characterization Activities}

Past-practice spills and documented hazardous waste releases to the S-10 facility has required an evaluation of soil contamination to evaluate and develop facility specific cleanup/closure options. An

Table 2.1. Composition of Synthetic Double-Shell-Tank Slurry

\begin{tabular}{||l|c|c||}
\hline \multirow{2}{*}{ Component } & \multicolumn{2}{c|}{ Concentration (molarity) } \\
\cline { 2 - 3 } & TK-505 & TK-509 \\
\hline \hline $\mathrm{Al}$ & 1.225 & 1.235 \\
\hline $\mathrm{OH}$ & 3.40 & 3.42 \\
\hline $\mathrm{NO}_{2}$ & 2.18 & 2.115 \\
\hline $\mathrm{NO}_{3}$ & 2.54 & 2.50 \\
\hline $\mathrm{CO}_{3}$ & 0.159 & 0.157 \\
\hline $\mathrm{PO}_{4}$ & 0.041 & 0.027 \\
\hline $\mathrm{SO}_{4}$ & $<0.052$ & $<0.052$ \\
\hline $\mathrm{F}$ & 0.062 & 0.05 \\
\hline $\mathrm{Cl}$ & 0.115 & 0.103 \\
\hline $\mathrm{Cr}$ & 0.106 & 0.0983 \\
\hline \hline
\end{tabular}




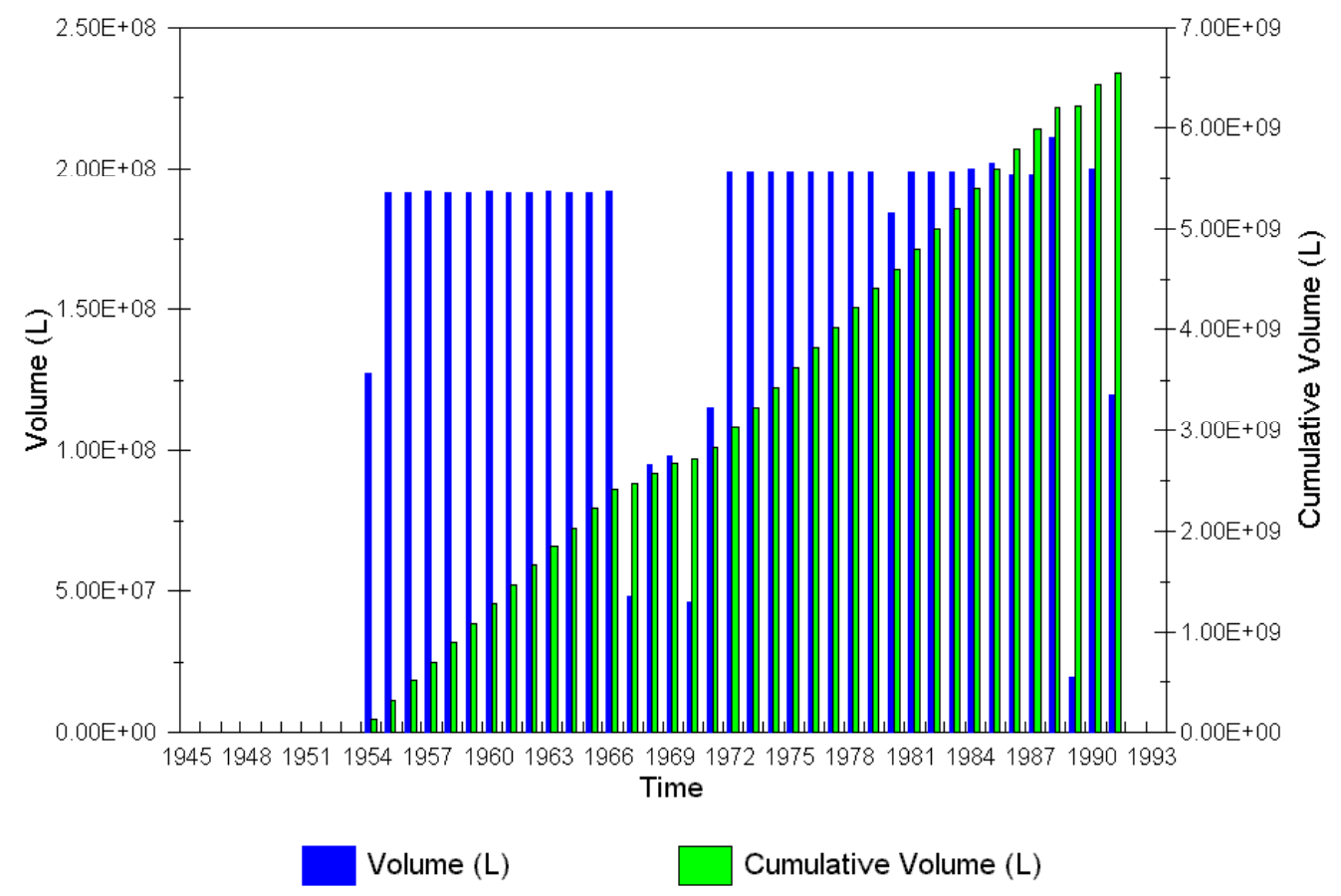

Figure 2.3. Effluent Volume Discharged to the 216-S-10 Ditch (216-S-10D), 216-S-10 Pond, and 216-S-11 Pond

integrated process for characterization of the RCRA regulated units within the CERCLA 200-CS-1 Operable Unit uses a RI/FS work plan in combination with the Implementation Plan (DOE/RL 1999) to satisfy the requirements for both a RI/FS work plan and a RCRA facility investigation/corrective measures study (RFI/CMS) work plan. Based on this approach a CERCLA work plan (DOE/RL 2000) was developed that provides details for characterizing chemical, radiological and physical conditions in the soil at the S-10 facility. After the characterization has been completed the results will be presented in a CERCLA remedial investigation report. This report will support the future evaluation of remedial alternatives and closure options.

The first phase of characterization was completed in 1999 and involved deep sediment sampling in one borehole drilled at the S-10 pond. The borehole was later completed as a RCRA downgradient monitoring well to replace RCRA well 299-W26-9 that had gone dry. A second phase of field characterization will begin in 2003 and includes shallow test pit excavations for soil sampling along the ditch and pond (sample analysis of sediment) and one deep characterization borehole along the S-10 ditch. The results of the RI/FS characterization effort will be presented in a draft RI report (TPA milestone M-015-39B), which is scheduled for regulatory review in 2004 (DOE/RL 2000).

\subsection{Constituents of Concern}

Site-specific constituents of concern are developed using the final list of contaminants of concern developed under the data quality objective process for the CERCLA 200-CS-1 Chemical Sewer Group Assessment excluding radioactive constituents as the base list. This CERCLA final list of contaminants 
was developed by evaluating it against a list of exclusion criteria and rationale. BHI (1999) provides the details of this elimination process. From the base list, several constituents are eliminated based on detection ability, mobility, or the magnitude of detected concentration (i.e., maximum values) in relation to the Hanford Site groundwater background values as presented in DOE/RL (1997), Table ES-1. The remaining constituents form the site-specific constituents and are listed below:

- Chromium

- Vanadium

- Carbon tetrachloride

- Chloroform.

A detailed process to derive the final list of site-specific constituents is provided in Section 6.3.2. 


\subsection{Hydrogeology}

This section summarizes available and new interpretations of the hydrogeology of the S-10 facility. Data on physical characteristics of the S-10 facility and the surrounding area (e.g., boreholes) are used to refine understanding of the local hydrogeology beneath the site and the potential contaminant transport pathways from the subsurface, toward groundwater and toward potential receptors. These data are used to develop the conceptual model beneath the site (Section 5.0). In addition, these data also are needed to provide engineering information to develop and screen remedial action alternatives. Early studies relied on limited borehole and well data to describe the stratigraphy and groundwater hydrogeology of the area. More wells have been drilled in recent years in the surrounding area specifically targeted to collect more characterization data. As a result, the quantity and quality of the geologic data has been enhanced, which helps the hydrogeologic model development and its interpretation.

The S-10 facility is located south-southwest of the 200 West Area on the Central Plateau, a broad, flat area that constitutes a local topographic high around the 200 Areas. The plateau is one of the flood bars (i.e., Cold Creek Bar) formed during the cataclysmic flooding events of the Missoula floods that occurred over 13,000 years ago. The northern boundary of the flood bar is defined by an erosional channel, and present day topographic low, that runs northwest-southeast near Gable Butte just north of the 200 West Area boundary (Williams et al. 2002). Most of the 200 West Area, including the S-10 facility, is situated on the flood bar (Figure 3.1).

The geology of the Central Plateau, and particularly the Pasco Basin, has been studied in great detail (DOE 1988). The focus of this section is on the sediment above the basalt bedrock, or the suprabasalt sediment, contained within the Hanford, Plio-Pleistocene, and Ringold Formations, because these strata comprise the uppermost aquifer system and vadose zone in the area. Detailed descriptions of these geologic units are available in Bjornstad (1984, 1985), Tallman (1979), Myers and Price (1981) Graham et al. (1981) and Lindsey (1995). The most detailed description of the stratigraphy beneath the S-10 facility could be found in Airhart et al. (1990).

Williams et al. (2002) provides an updated re-interpretation of the hydrogeology in the 200 West Area and vicinity that includes characterization of the entire suprabasalt aquifer system. The most recent description of the groundwater contamination in the region of the Hanford Site surrounding the S-10 facility is presented in Hartman et al. (2002).

\subsection{Stratigraphy}

Two separate Hanford Site stratigraphic classifications are available (Figure 3.2); one developed by Lindsey (1995) is based on lithology (labeled Geology Column), and the second, developed by Pacific Northwest National Laboratory (PNNL) (Wurstner et al. 1995; Thorne et al. 1993), is the hydrogeologic stratigraphy (labeled Hydrogeologic Column) that combines the geology with the hydrologic properties (see also Wurstner et al. 1995). This plan uses PNNL's hydrogeologic classification because it is more applicable to groundwater movement in the suprabasalt sediment. This hydrogeologic nomenclature and its geologic relationship are illustrated in Figure 3.2. The uppermost suprabasalt aquifer system is 


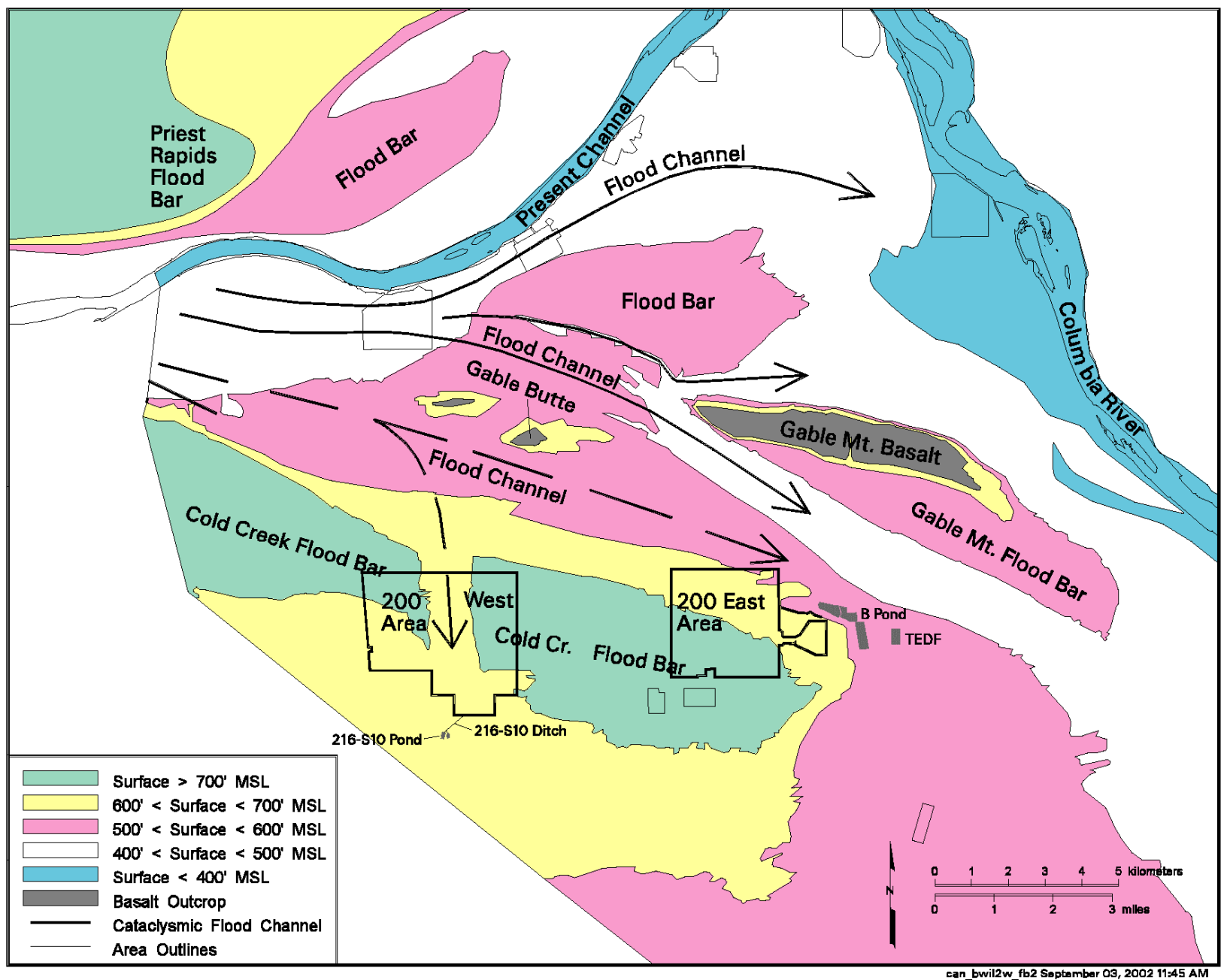

Figure 3.1. Topographic Illustration of Pleistocene Flood Channels and the Present-Day Columbia River Channel Pathways, with Outlines of the 200 West and East Areas, Hanford Site, Washington

contained in the Ringold Formation, and the Hanford formation and Plio-Pleistocene unit comprise the vadose zone. The Ringold Lower Mud Unit (hydrogeologic unit 8) separates the supra basalt aquifer system into a confined and unconfined aquifer (Williams et al. 2002). The uppermost surface of the Elephant Mountain member basalt is considered the base of the suprabasalt aquifer system (bedrock) because of its dense, low permeability interior, relative to the overlying sediments. This surface is considered to be a groundwater no-flow boundary. The basalt surface beneath the S-10 facility dips south-southwest forming the southern limb of the Gable Mountain-Gable Butte anticline and the northeast flank of the Cold Creek syncline [after Fecht et al. (1987)]. Figures 3.3 (south-north) and Figure 3.4 (east-west), two cross sections from Williams et al. (2002), illustrate the stratigraphic position and relationship of these hydrogeologic units as they exist beneath the southern 200 West Area and the S-10 facility. Figure 3.5 provides a more detailed hydrogeologic profile beneath the S-10 facility. 


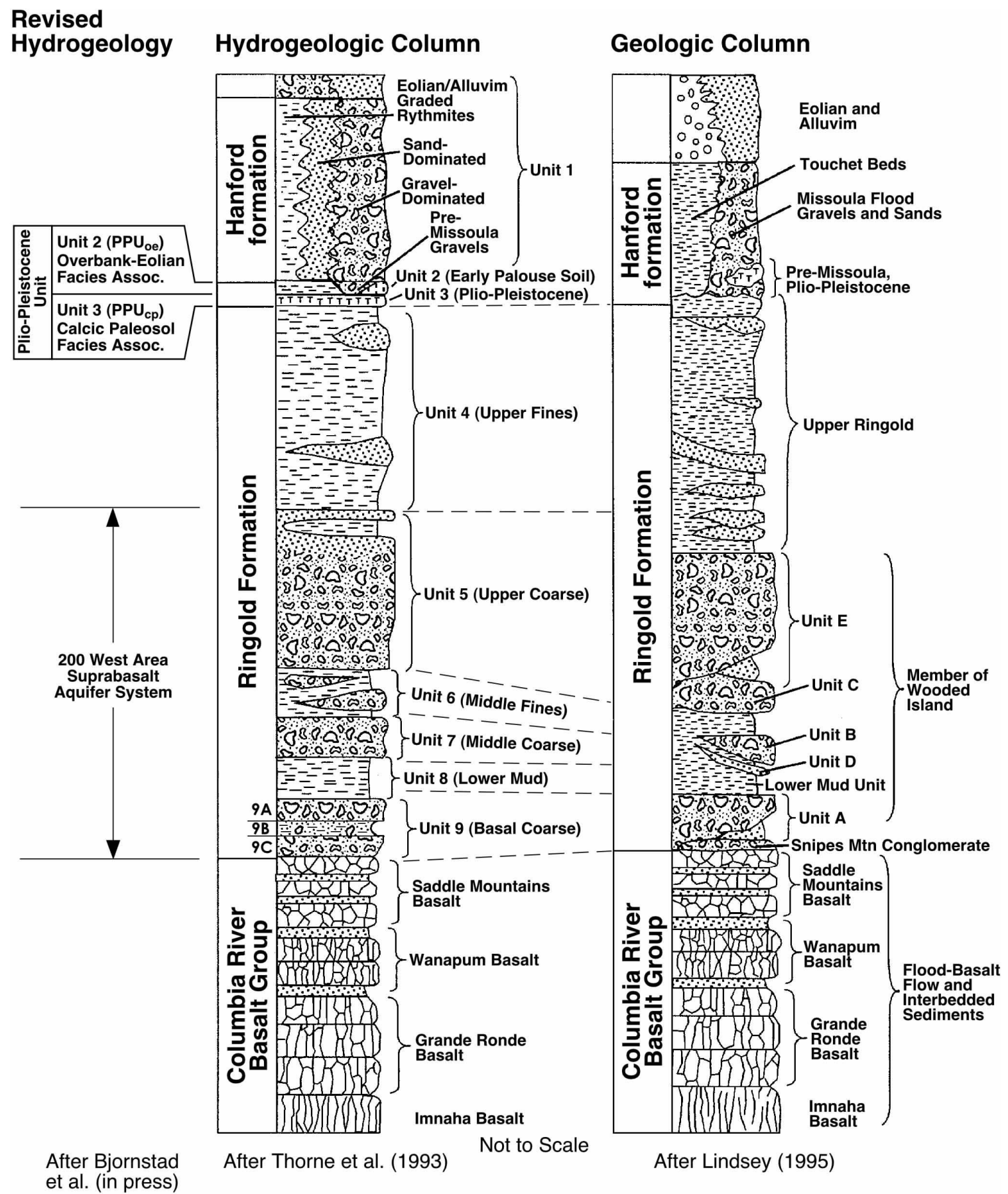

2002/DCL/200W HGS/002

Figure 3.2. Comparison of Hydrogeologic and Geologic Classifications ${ }^{(a)}$

(a) Bjornstad, B. N., G. V. Last, G. A. Smith, K. A. Lindsey, K. R. Fecht, S. P. Reidel, D. B. Horton and B. A. Williams. Draft 2001. Proposed Standardized Stratigraphic Nomenclature for Post-RingoldAge Sedimentary Deposits Within the Central Pasco Basin. White Paper, Pacific Northwest National Laboratory, Richland, Washington. 


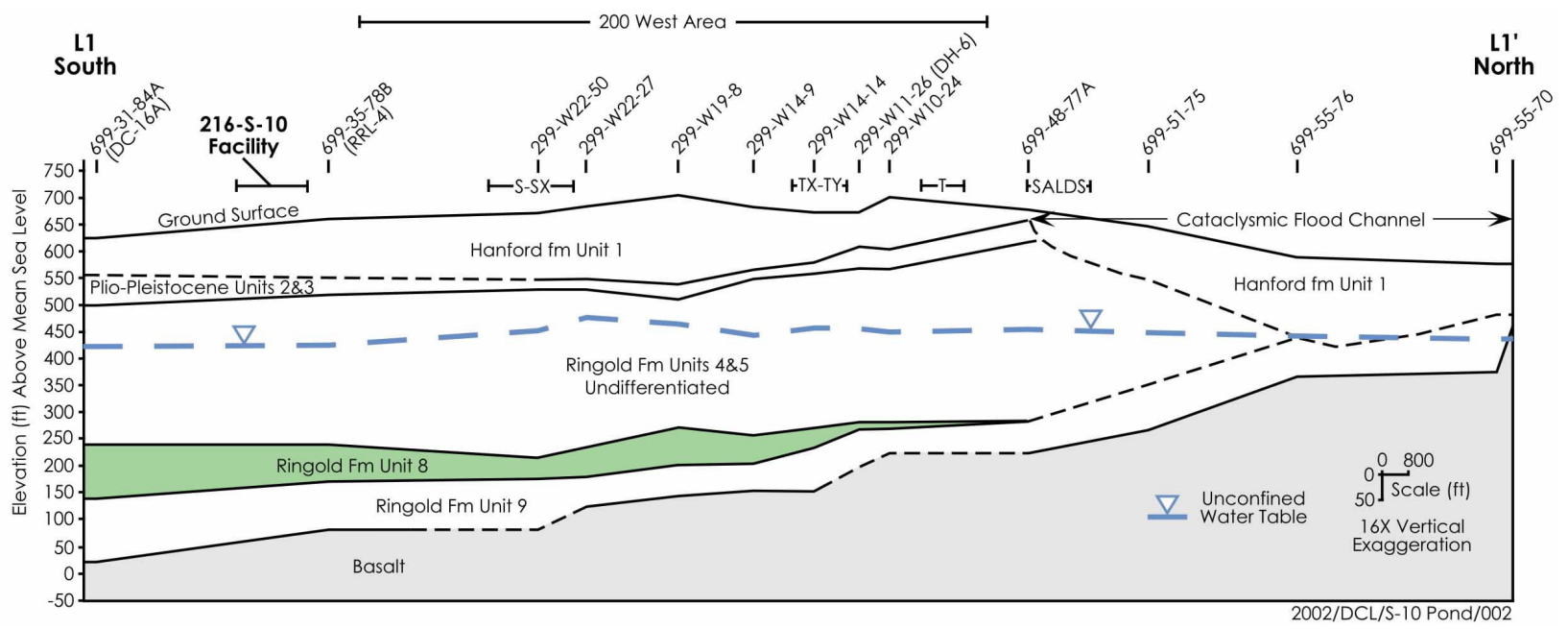

Figure 3.3. Hydrogeologic South-North Cross Section in the 200 West Area and Near S-10 Facility

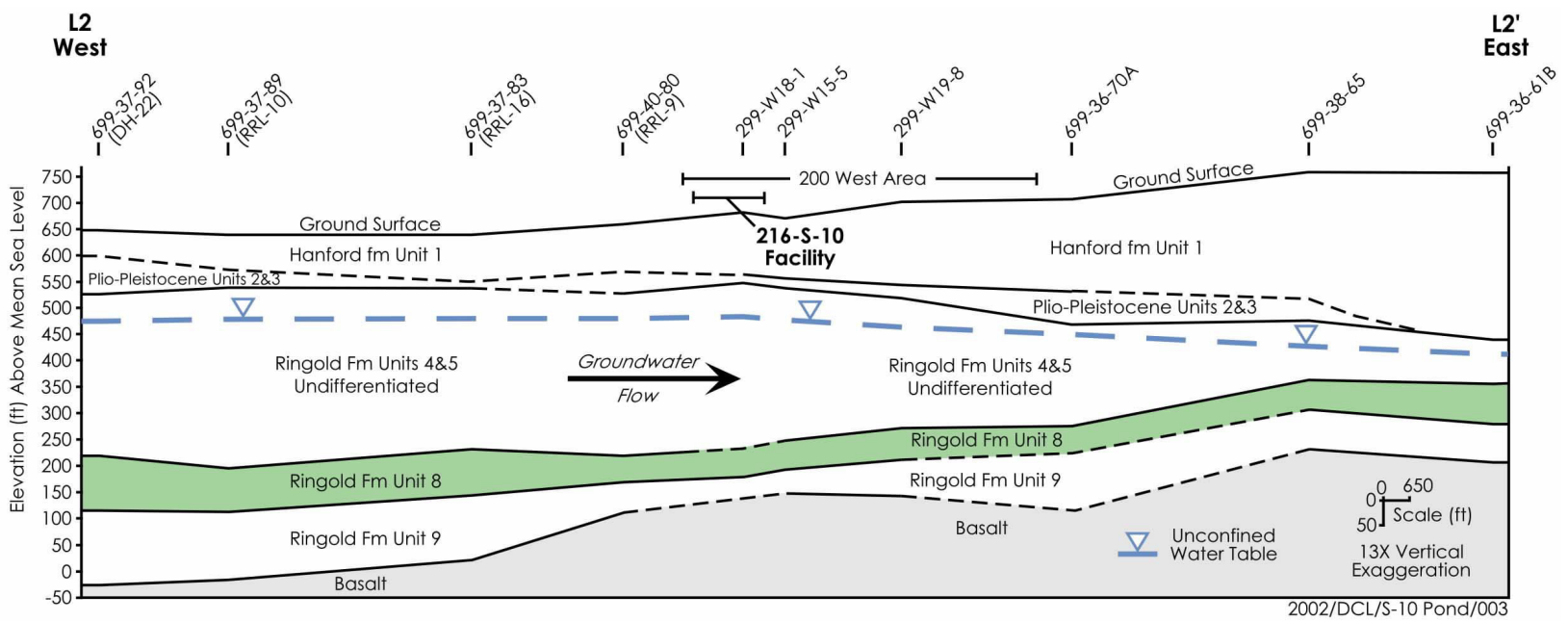

Figure 3.4. Hydrogeologic East-West Cross Section in the 200 West Area and Near S-10 Facility

The S-10 facility lies at an elevation of about $200 \mathrm{~m}(\sim 650 \mathrm{ft})$ above mean sea level. The stratigraphy at the S-10 facility includes the following (from lower to upper):

- Ringold Formation

- Plio-Pleistocene Unit

- Hanford formation.

Geology beneath the S-10 facility is described in detail in the following paragraphs. 


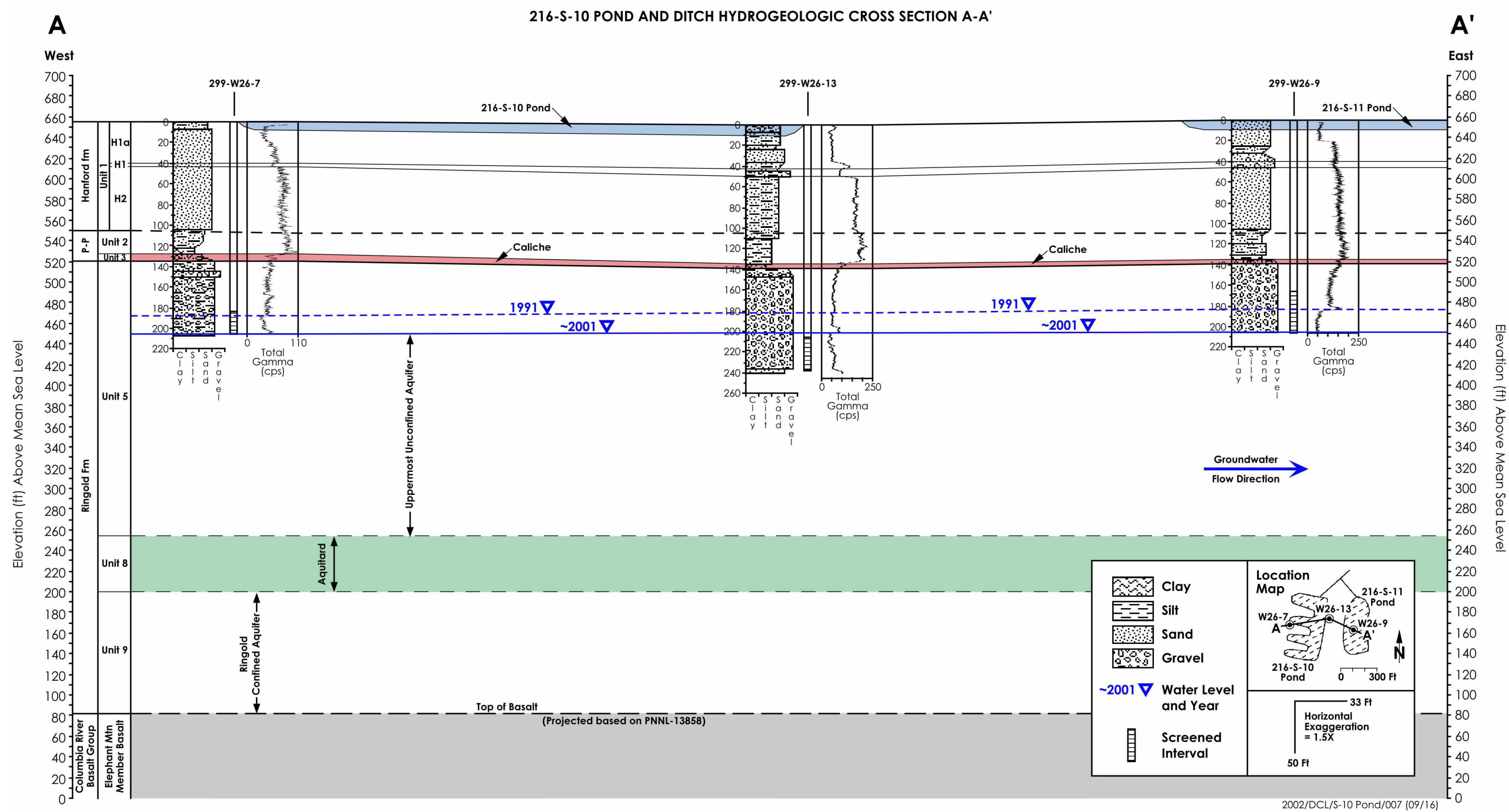

Figure 3.5. Detailed Hydrogeologic Cross Section at the S-10 Facility 


\subsubsection{Ringold Formation (Units 4 through 9)}

Units 4 through 9 correspond to the Ringold Formation (see Figure 3.2) and consist of continental fluvial and lacustrine sediments deposited on the Elephant Mountain member basalt by ancestral Columbia and Clearwater-Salmon Rivers during late Miocene to Pliocene time (DOE 1988). From the oldest to youngest, the stratigraphic intervals are the Unit 9 fluvial gravel, Unit 8 composed of the paleosol/overbank facies beneath lacustrine fine-grained facies (Bjornstad 1984; DOE 1988; Last et al. 1989; Bjornstad 1990), Unit 5 fluvial gravel, and Unit 4 fines.

Ringold Units 4 through 9 consist of intercalated layers of indurated to semi-indurated and/or pedogenically altered sediment, including clay, silt, fine-to-coarse grained sand, and granule-to-cobble gravel. Within the area of the S-10 facility, this sequence consists of only three distinct stratigraphic intervals designated Units 5, 8, and 9. Units 5, 8, and 9 correspond generally to Lindsey's Ringold Formation fluvial gravel Unit E, lower mud unit and fluvial gravel Unit A, respectively (see Figure 3.2).

Unit 9. The Ringold Unit 9 gravel is located between 140 to $149.5 \mathrm{~m}$ (460 to $490 \mathrm{ft}$ ) beneath the S-10 facility and ranges up to $30.5 \mathrm{~m}$ (100 ft) thick. This unit dips to the south-southwest and lies unconformably on top of the Columbia River Basalt. Unit 9 is composed primarily of semi-consolidated and cemented silty sandy gravel with secondary lenses and interbeds that can consist of gravel, gravely sand, sand, muddy sand, and/or silt/clay.

Unit 8 (Lower Mud Unit). Unit 8 is composed of a thick sequence of fluvial overbank, paleosol, and lacustrine silts and clay with minor sand and gravel. Unit 8 forms the most significant and extensive confining unit within the suprabasalt aquifer system at the Hanford Site (Williams et al. 2000). More detailed descriptions of Unit 8 (the lower mud unit) can be found in Lindsey (1995). This unit is between 12 to $21 \mathrm{~m}$ (40 to $70 \mathrm{ft})$ thick and located approximately $129 \mathrm{~m}(423 \mathrm{ft})$ beneath the S-10 facility.

Unit 5. The Ringold Unit 5 gravel is a relatively thick unit, ranging up to $76 \mathrm{~m}$ (250 ft) thick, composed primarily of indurated fluvial gravel to silty sandy gravel and sand that grades upward into Unit 4 (interbedded fluvial sand and silt). Unit 5 has not been subdivided further due to the lack of distinctive and correlable stratigraphy or lithologic units. The saturated portion of Unit 5 comprises the uppermost unconfined aquifer and is over $58 \mathrm{~m}$ (190 ft) thick beneath the S-10 facility. Unit 5 overlies the Unit 8 (Ringold lower mud unit).

Unit 4. The Ringold Unit 4 is only locally present in the 200 West Area, and consists of fluvial sand and silt that overlies the Ringold Unit 5 gravel. This unit is not present in the wells surrounding the S-10 facility. More information on the areal extent and details of this unit can be found in Lindsey (1995).

\subsubsection{Plio-Pleistocene Unit (Units 2 and 3)}

Units 2 and 3 represent relatively thin but significant depositional units that are post-Ringold and preHanford sedimentation. Unit 3 is a calcic paleosol horizon that has developed on the eroded Ringold Formation (either Unit 4 or 5). Unit 3 is commonly referred to as the calcic sequence (or "caliche" zone) and is also referred to as the lower Plio-Pleistocene unit $\left(\mathrm{PPU}_{\mathrm{cp}}\right)$. Unit 2 is described as an overlying 
fine-grained overbank-eolian sequence considered to belong to the upper portion of the Plio-Pleistocene Unit $\left(\mathrm{PPU}_{\text {оe }}\right)$. It is equivalent to what has been called the early "Palouse" soil (Connelly et al. 1992) in previous reports. Unit 3 is easily differentiated from the underlying (Unit 5) and overlying overbankeolian sequence (Unit 2) because it is highly weathered, heavily cemented with calcium carbonate, poorly sorted, and shows a distinct decrease in natural gamma activity compared to the upper Unit 2, which is very fine grained, un-cemented, consisting of alternating thin lenses (typically less than $15.2 \mathrm{~cm}$ [6 in.]) of very fine sand to silt and clay, and has a relatively high natural gamma activity. The stratigraphic contact between the Unit 3 and the Ringold Unit 5 is fairly distinct and sharp, whereas the contact between the Unit 2 and the overlying Hanford Unit 1 is gradational, dependent on grain size. In most cases, geophysical gamma logs greatly improve the accuracy of these correlations. Figure 3.5 illustrates these contacts near the southern end of the facility.

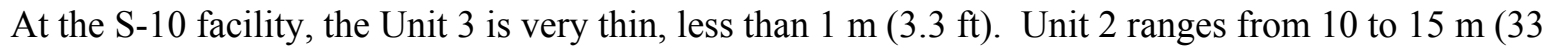
to $50 \mathrm{ft}$ ) thick. Unit 2 is located from approximately 33 to $43 \mathrm{~m}$ (110 to $140 \mathrm{ft})$ in depth below the surface.

\subsubsection{Hanford Formation (Unit 1)}

The Hanford formation is the informal name given to Pleistocene-age cataclysmic flood deposits in the Pasco Basin (Lindsey et al. 1994). It consists predominantly of unconsolidated sediments, which cover a wide range in grain size from pebble- to boulder-gravel, fine- to coarse-grained pebbly sand to sand, silty sand, and silt. Gravel clasts are composed of mostly subangular to subrounded basalt. Beneath the S-10 facility the Unit 1 consists of essentially three facies, the lower facies (Hanford $\mathrm{H}_{2}$ unit) is composed of fine-grained sand to sandy silt that ranges from 12 to $18 \mathrm{~m} \mathrm{(40} \mathrm{to} 60 \mathrm{ft})$ in thickness. This fine-grained facies is overlain with a fine to coarse sand to sandy gravel sequence that ranges from 1 to $3 \mathrm{~m} \mathrm{(3} \mathrm{to} 10 \mathrm{ft}$ ) in thickness. This coarse grained interval is designated the Hanford $\mathrm{H}_{1}$ unit and is similar to the same zone described at Johnson and Chou (1999, Figure B.8). The uppermost fine grained sequence is designated the Hanford $\mathrm{H}_{1 \mathrm{a}}$ unit.

\subsection{Physical Hydrogeology}

Information on the vadose zone and the suprabasalt aquifer system at the S-10 facility is obtained from well-log data for wells and boreholes surrounding the facility and from published reports. In the 200 West Area and vicinity of S-10 facility, Williams et al. (2002) uses data from borehole and groundwater monitoring to subdivide the suprabasalt sediments into two aquifers, an upper unconfined (Hanford/ Ringold) unconfined aquifer) and a lower confined (Ringold confined aquifer). The hydrogeology beneath the S-10 facility utilizes their interpretation.

The uppermost aquifer beneath the S-10 facility is unconfined; the aquifer comprises the saturated portion of the Ringold Unit 5 and is approximately $58 \mathrm{~m}$ (190 ft) thick (2001 measurement). Most known contaminant plumes that emanate from the 200 West Area migrate through Unit 5 toward the east. The groundwater flow direction is approximately east to southeast and is calculated based on water-level measurements taken in network and surrounding wells (e.g., Plate 1 in Hartman et al. 2002).

Site-specific hydraulic conductivity values, derived from constant discharge test data at two wells near the S-10 facility, range from 10 to $150 \mathrm{~m}$ (33 to $492 \mathrm{ft}$ ) per day (Williams and Barnett 1993 and Kipp 
and Mudd 1973). These values are within the range of hydraulic conductivities presented in Table 3.1 that have been calculated for hydrogeologic units beneath the 200 West Area.

These data reflect averages of data collected from wells throughout the Central Plateau. Based on these values and parameters listed in Hartman et al. (2002, Table A.2), the groundwater flow rate (Darcy velocity) ranges from 0.053 to $2.55 \mathrm{~m}(0.17$ to $8.4 \mathrm{ft})$ per day.

Within the 200 West Area, including the S-10 facility, the water table is declining rapidly due to sitewide cessation of past (non-permitted) liquid effluent disposal practices. Hydrographs for monitoring wells near the S-10 facility are presented in Figure 3.6. The falling water table is causing wells in the S-10 network and surrounding monitoring wells to go dry (see Figure 3.6).

Table 3.1. Hydraulic Conductivities for Major Hydrogeologic Units

\begin{tabular}{||l|c|l||}
\hline \multicolumn{1}{|c|}{ Hydrogeologic Unit } & $\begin{array}{c}\text { Estimated Range of Saturated } \\
\text { Hydraulic Conductivities (m/d) }\end{array}$ & \multicolumn{1}{|c||}{ Reference(s) } \\
\hline \hline $\begin{array}{l}\text { Unit 5 } \\
\text { (Ringold Formation Unit E) }\end{array}$ & 0.1 to 200 & $\begin{array}{l}\text { Wurstner et al. (1995): Thorne and } \\
\text { Newcomer (1992) }\end{array}$ \\
\hline $\begin{array}{l}\text { Unit 8 } \\
\text { (Ringold Formation Lower Mud Unit) }\end{array}$ & 0.0003 to 0.09 & $\begin{array}{l}\text { Wurstner et al. (1995): Thorne and } \\
\text { Newcomer (1992) }\end{array}$ \\
\hline $\begin{array}{l}\text { Unit 9 undifferentiated } \\
\text { Ringold Formation Unit A }\end{array}$ & $\begin{array}{l}\text { Wurstner et al. (1995): Thorne and } \\
\text { Newcomer (1992) }\end{array}$ \\
\hline Note: This table is modified from Cole et al. (1997). & \\
\hline
\end{tabular}

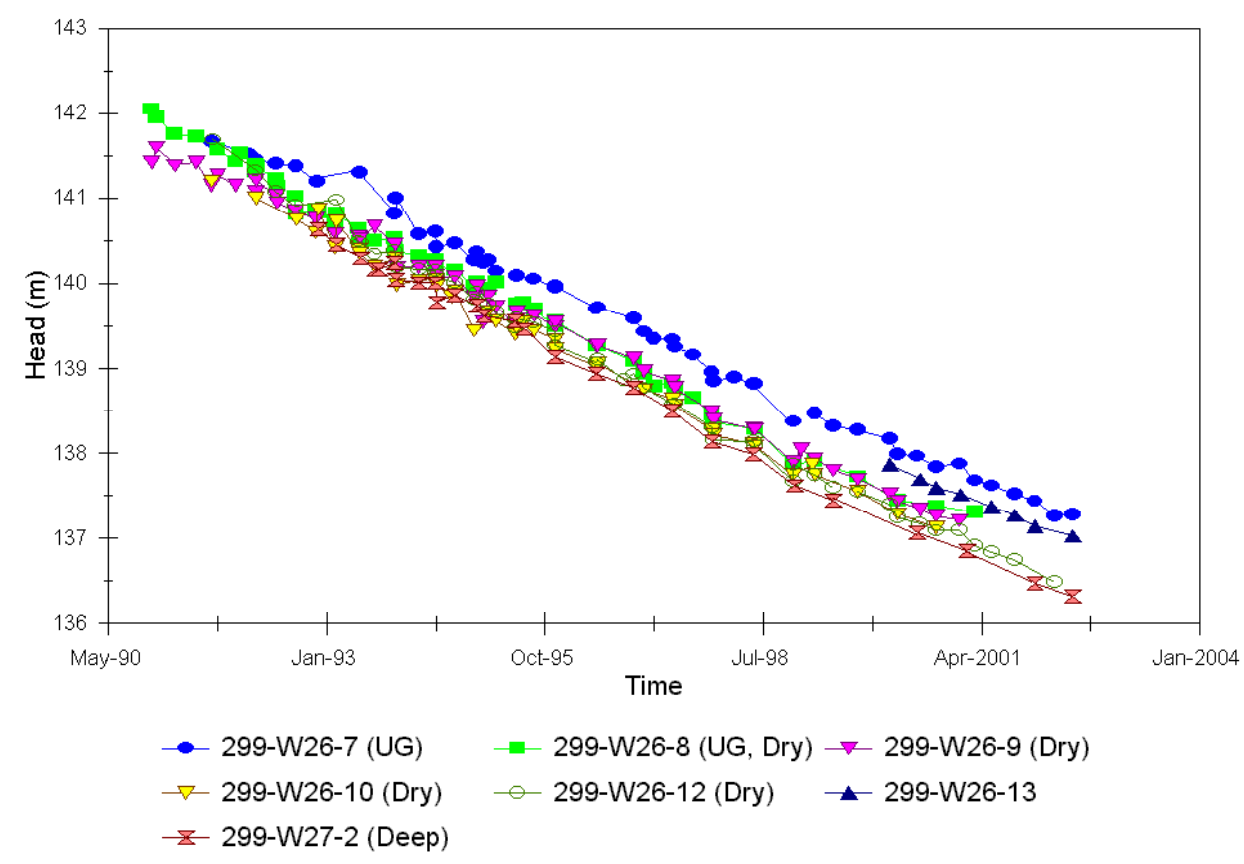

Figure 3.6. Hydrographs of Wells Monitoring the S-10 Facility 
It is not known if preferential paths of groundwater flow exist in this thick uppermost aquifer, or if flow path changes are occurring due to falling water levels, because existing Unit 5 hydrogeologic data has not supported subdivision of the unit into more discrete flow zones. However, the depositional nature and character of this unit, and the lithologic variability between boreholes, indicates that lithologic variations do occur on all scales; the intrinsic hydrologic properties will influence groundwater movement. The preferred method used to intercept and monitor the uppermost aquifer flow zone(s) has resulted from the requirement to install longer screens to maximize well life. Monitoring screens are being installed up to $10 \mathrm{~m}$ (35 ft) long depending on location and aquifer thickness.

The vertical hydraulic variability in the aquifer has not been evaluated at S-10 facility. However, data from nearby wells indicate that contaminants from other disposal operations have spread vertically and laterally throughout most of the unconfined aquifer beneath the 200 West Area (Williams et al. 2002). Carbon tetrachloride has been detected above the maximum contaminant level at the base of the upper unconfined aquifer in deep monitoring well 299-W27-2 (see Section 4.0).

The top of Unit 8 (lower mud unit) comprises the base of the uppermost-unconfined aquifer (Williams et al. 2002). Beneath the S-10 facility the vertical hydraulic conductivity of Unit 8, as measured from a splitspoon soil sample collected in well 299-W27-2, is $0.051 \mathrm{~m}(0.17 \mathrm{ft})$ per day and falls within the expected range reported by Thorne and Newcomer (1992) (see Table 3.1).

The Unit 8 (lower mud unit) is an aquitard and separates and confines groundwater in the underlying Ringold Unit 9 gravel (confined Ringold aquifer) from the unconfined aquifer in Unit 5. Groundwater in the confined Ringold aquifer is interpreted to flow laterally through Unit 9 gravel due to the thickness and relatively low vertical hydraulic conductivity of the overlying confining Unit 8.

Regionally, groundwater in the confined Ringold aquifer flows from west to east similar to groundwater in the uppermost unconfined aquifer. In the 200 West Area and around the S-10 facility, it is more difficult to determine flow direction because there are currently no wells completed within the confined Ringold aquifer. Limited data are available below the confining Unit 8 (lower mud unit) for the 200 West Area; however, groundwater heads measured in several deep/shallow well pairs, and deep wells drilled into the Ringold Unit 9 confined aquifer (e.g., Johnson and Horton 2000) indicate a downward vertical hydraulic gradient beneath the 200 West Area from the unconfined Unit 5 into the confined Unit 9 (Williams et al. 2002).

Beneath the S-10 facility, groundwater in the uppermost unconfined aquifer is assumed to be isolated from groundwater in the confined Ringold aquifer by Unit 8 (lower mud unit). Intercommunication between Units 5 and 9 is assumed to be insignificant because groundwater flow through Unit 8 is extremely low due to the thickness and relative permeability of the confining unit.

The vadose zone beneath the S-10 facility is up to $71 \mathrm{~m}(233 \mathrm{ft})$ thick. The vadose includes hydrogeologic Units 1, 2, 3 and the upper, unsaturated portion of Unit 5 (see Figure 3.2). Figure 3.5 provides input to the conceptual model for the area near the S-10 and S-11 ponds and includes depths, relative thicknesses, and hydraulic relationship of the hydrogeologic units beneath the facility. 
Recharge to the unconfined aquifer beneath the S-10 facility is from artificial and possibly natural sources. Any natural recharge that occurs originates from precipitation. Estimates of recharge from precipitation range from 0 to $10 \mathrm{~cm}$ ( 0 to 4 in.) per year and are largely dependent on soil texture and the type and density of vegetation (DOE/RL 2000). While the liquid waste disposal facilities were operating, many localized areas of saturation or near saturation were created in the soil column. Artificial recharge from years of liquid effluent disposal accounts for most of the liquid influx to the aquifer and is the main driver and transport medium for potential contaminants disposed at the facility. Perched water, created due to liquid effluent disposal to the S-10 ditch, has occurred, and was observed above the PlioPleistocene Unit 3. Well 299-W26-11, located near the pipeline inlet end of the S-10 ditch (north end), monitored this perched water interval until the well went dry after liquid effluent disposal ceased at the facility.

The downward flux of moisture in the vadose zone decreased with the cessation of artificial recharge in the S-10 area. Areas with high residual water saturation in the sediment will result in continued gravity drainage for an unknown period of time. When stable unsaturated conditions are reached, the moisture flux into the aquifer becomes less significant. In the absence of artificial recharge, the potential for recharge from precipitation becomes more important as a driving force for any potential contamination remaining in the vadose zone. 


\subsection{Summary of Groundwater Monitoring Results}

Prior to RCRA groundwater monitoring, the S-10 facility was monitored by various means including effluent stream sampling, surface radiation surveys, aerial radiation surveys, composite weekly water quality samples from the ditch, and sediment and vegetation samples (DOE/RL 2000). Sampling and analysis of groundwater at the S-10 facility has been conducted under RCRA interim status requirements since the third quarter of 1991. Since 1991, RCRA monitoring at the S-10 facility has not detected any significant impact to groundwater based on upgradient-downgradient indicator parameter statistical comparisons.

This section summarizes significant results of groundwater analyses for the S-10 facility through December 2001 using all the WAC compliant (WAC 173-160) groundwater monitoring wells installed in 1990 and 1991 (Appendix A). Wells 299-W26-7, 299-W26-8, 299-W26-9, 299-W26-10, and 299-W26-12 monitored the upper 4.5 to $6 \mathrm{~m}$ (15 to $20 \mathrm{ft}$ ) of the uppermost aquifer. Well 299-W26-11 was completed in a perched water zone above the Plio-Pleistocene Unit 2 and 3 to monitor apparent perched effluent recharging to the aquifer. Well 299-W27-2 was installed in 1992 and monitors the lower $3 \mathrm{~m}(10 \mathrm{ft})$ of the uppermost aquifer, just above the Unit 8. Currently, only one of the original six upper aquifer monitoring wells, 299-W26-7, remains in service due to declining water levels. Not including the perched aquifer well, four wells have gone dry, at an average rate of one well per year starting in early 1998; the last upgradient well 299-W26-7 is projected to go dry in 2003. Only one replacement well, 299-W26-13, has been added to the network (completed in December 1999) near the S-10 pond.

\subsection{Contamination Indicator Parameters}

Required statistical evaluations of the contamination indicator parameters (specific conductivity, $\mathrm{pH}$, total organic carbons, and total organic halides) have been conducted since 1992, immediately after background values were established (see Section 7.3 for statistical method). Since then, background values have been revised several times to reflect the changes in site conditions (e.g., wells gone dry). The most recently revised values for the upgradient/downgradient comparisons can be found in Section 7.3. Statistical evaluations of indicator parameters have not indicated that the S-10 facility has affected the groundwater quality in the uppermost aquifer beneath the site.

\subsection{Metals}

Filtered metals have been measured using the inductively coupled plasma method. Cadmium, copper, mercury, selenium, and silver are essentially not detected. Of those consistently detected metals, the maximum detected values for arsenic, barium, and beryllium are less than the Hanford sitewide groundwater background. Chromium and lead are higher in the upgradient well 299-W26-7. (Note: lead and mercury have not been analyzed since July 1993). Nickel is elevated in the deep well 299-W27-2. Concentrations versus time plots for selected metals are presented in Figure 4.1 through 4.7. Metals with the highest concentrations that either approach or exceed their maximum contaminant level (chromium and nickel) are discussed in more detail in the following paragraphs. 


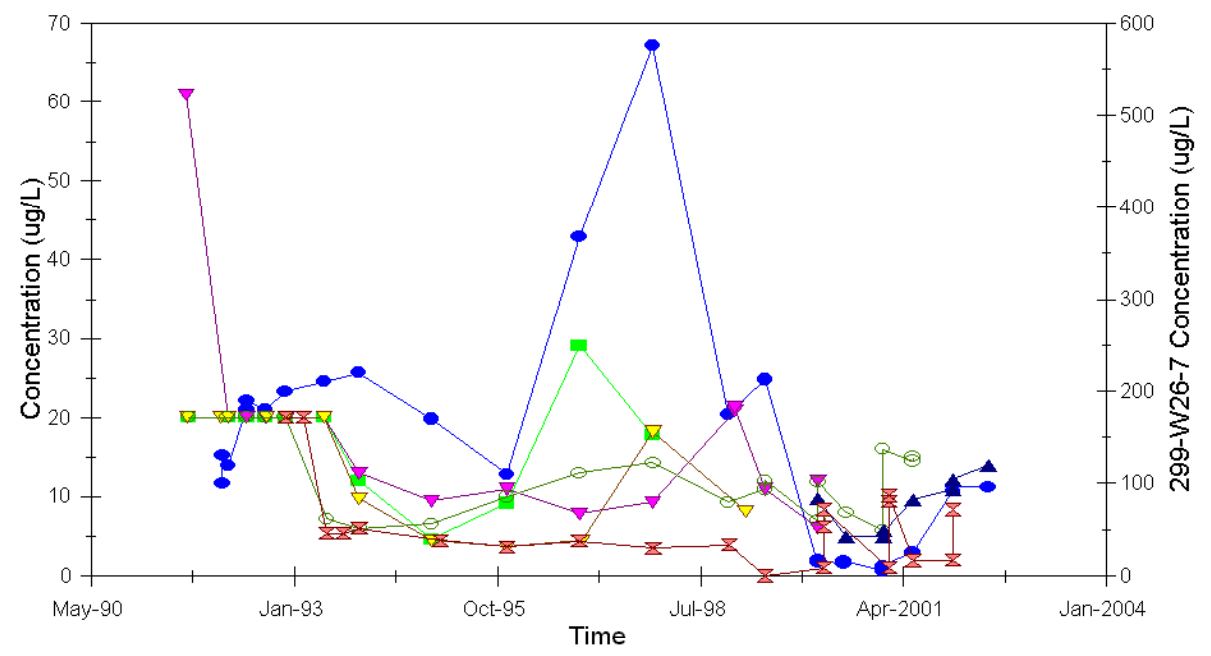

$$
\begin{aligned}
& -2 \text { 299-W26-7 (UG) } \quad-\text { - 299-W26-8 (UG, Dry) } \rightarrow-299-W 26-9 \text { (Dry) } \\
& \rightarrow \text { 299-W26-10 (Dry) } \quad \odot \text { 299-W26-12 (Dry) } \quad \text { 299-W26-13 } \\
& \approx \text { 299-W27-2 (Deep) }
\end{aligned}
$$

Figure 4.1. Chromium Concentrations Versus Time (Filtered; note: different scale for 299-W26-7)

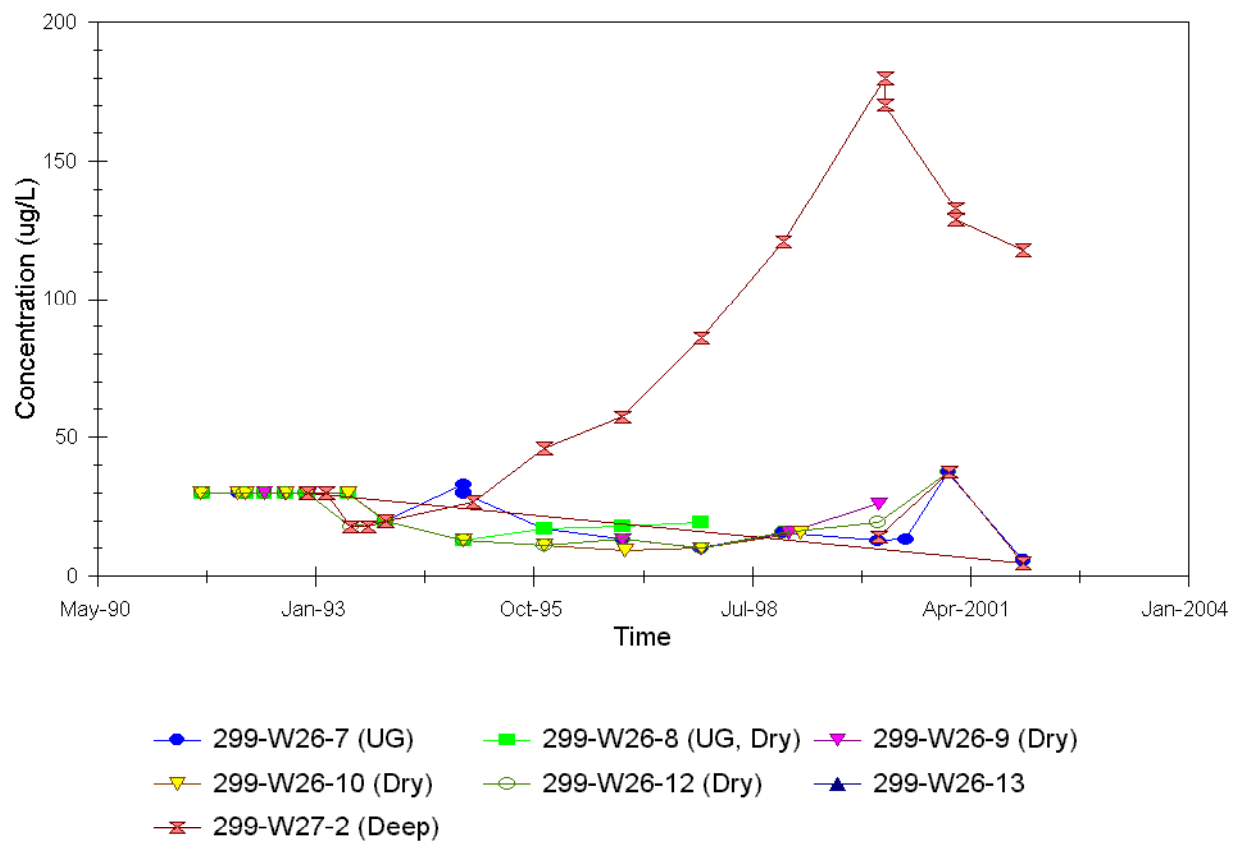

Figure 4.2. Nickel Concentrations versus Time (Filtered) 


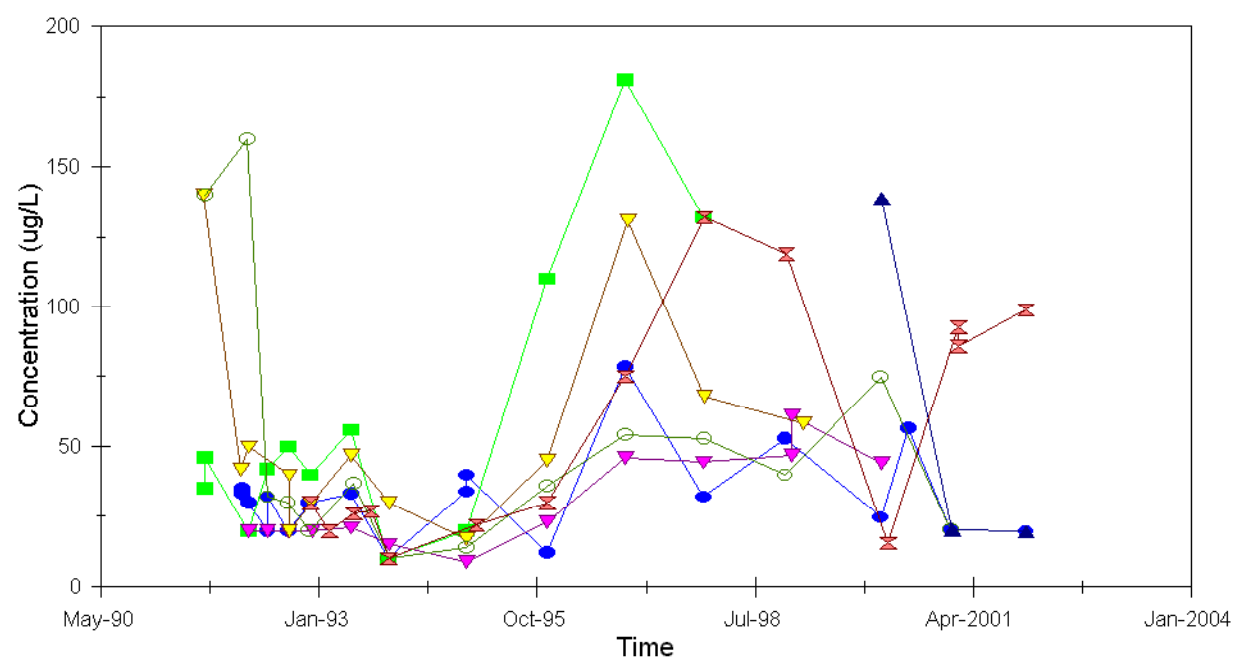

$\rightarrow$ 299-W26-7 (UG) $\quad-$ 299-W26-8 (UG, Dry) $\rightarrow$ 299-W26-9 (Dry)
$\rightarrow-299-W 26-10$ (Dry) $\quad \odot$ 299-W26-12 (Dry) $\rightarrow$ 299-W26-13
$\because$ 299-W27-2 (Deep)

Figure 4.3. Iron Concentrations versus Time (Filtered)

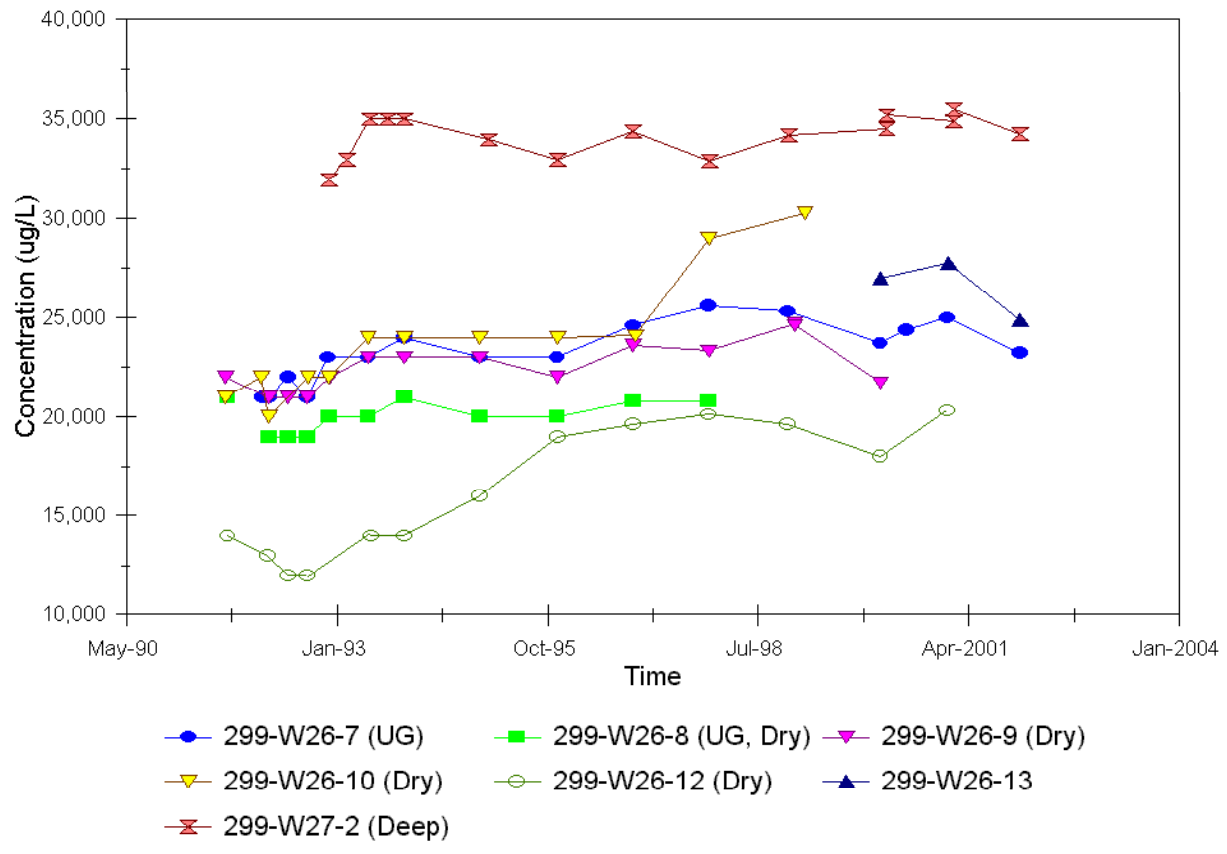

Figure 4.4. Calcium Concentrations versus Time (Filtered) 


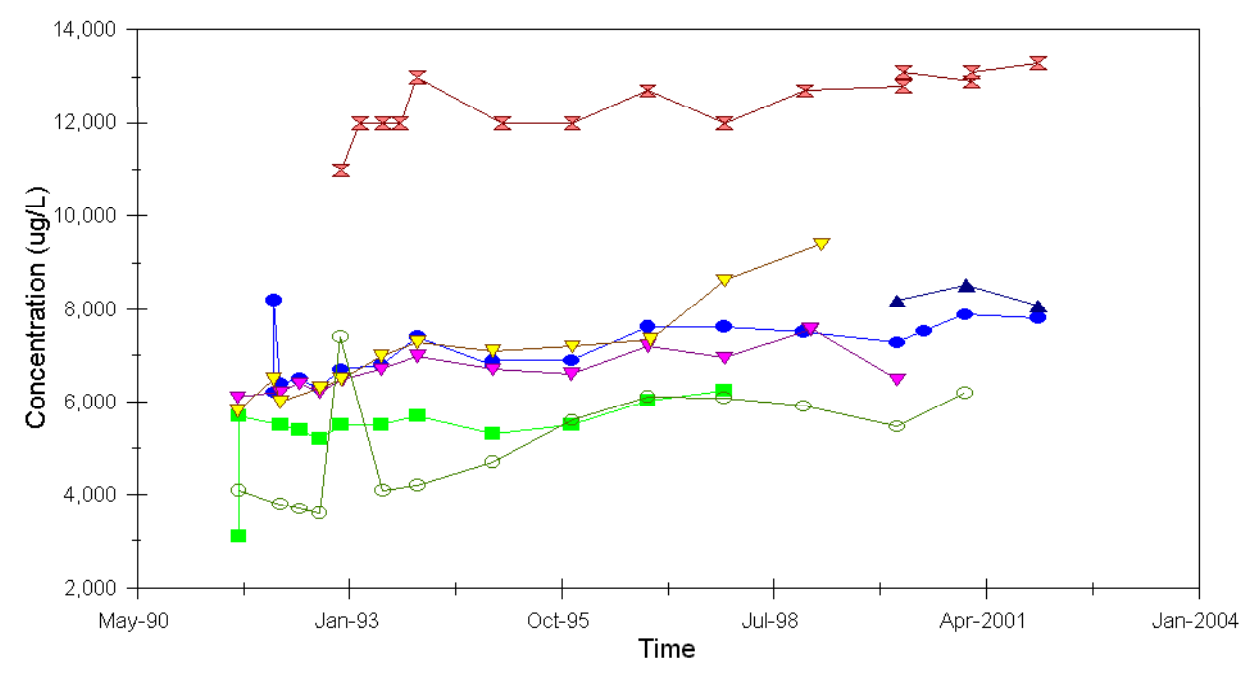

$$
\begin{aligned}
& \rightarrow \text { 299-W26-7 (UG) } \quad-\text { 299-W26-8 (UG, Dry) } \rightarrow \text { 299-W26-9 (Dry) } \\
& \rightarrow \text { 299-W26-10 (Dry) } \odot \text { 299-W26-12 (Dry) } \leftarrow \text { 299-W26-13 } \\
& \quad \text { ¿ 299-W27-2 (Deep) }
\end{aligned}
$$

Figure 4.5. Magnesium Concentrations versus Time

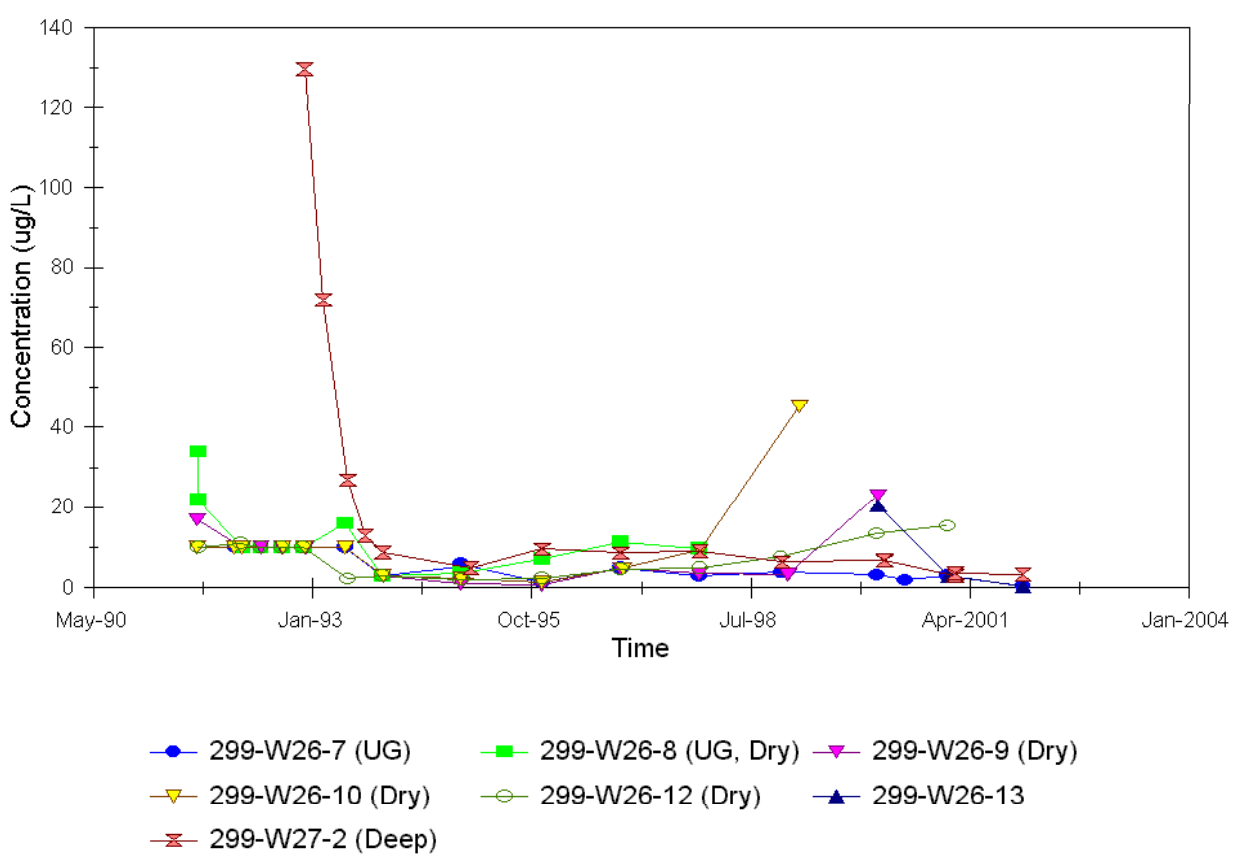

Figure 4.6. Manganese Concentrations versus Time 


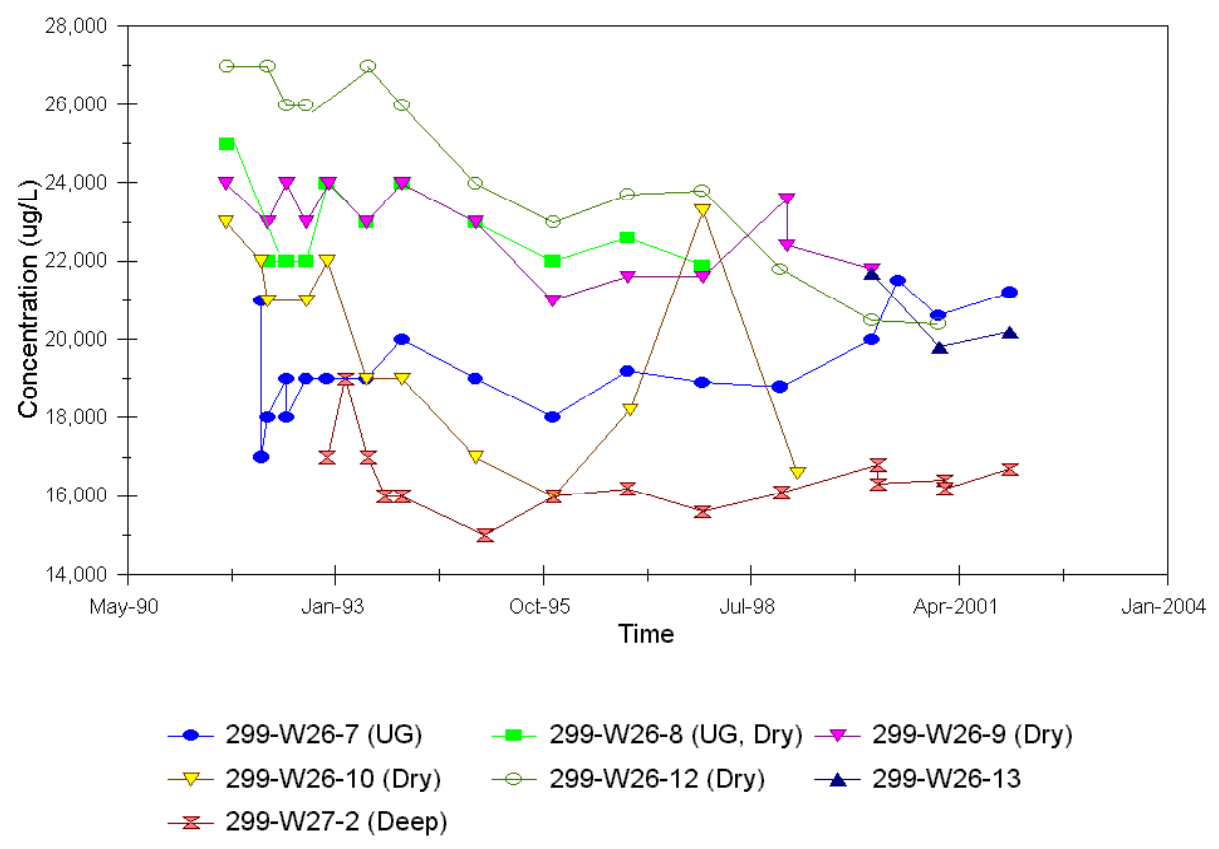

Figure 4.7. Sodium Concentrations versus Time

Chromium concentrations, especially in well 299-W26-7, increased above the maximum contaminant level (highest value $=576 \mu \mathrm{g} / \mathrm{L}$ ) and then dropped below the maximum contaminant level between October 1995 and July 1998, suggesting a transient release event. Historical records indicate the release to the S-10 facility of a high-salt waste (simulated tank waste) containing hexavalent chromium. For example, a one-time release of 416.4 L (110 gal) of synthetic double-shell tank waste was released to the ditch and pond system in September 1983. Assuming a transport time of several years through the vadose zone to groundwater, and considering the volume of water and mass of chromium (approximately 3,000 grams as chromium and a discharge rate of 10 million L [2.64 million gal] per month), the observed transient and approximate chromium concentrations are consistent with the $416.4 \mathrm{~L}$ (110 gal) release event. Although well 299-W26-7 is an upgradient well, it is located very close to one lobe of the pond system. Wastewater from the pond may have intersected the nearby monitoring well by spreading laterally in the subsurface. Other co-contaminants, especially nitrate, should be elevated as well during this same time period, as discussed later under anions.

Nickel is present at concentrations above the maximum contaminant level in the one deeper well (299-W27-2, completed at the bottom of the aquifer). This well also has higher but steady concentrations of calcium and magnesium with lower sodium concentrations as compared to the wells that monitor top portion of the aquifer. The long, gradual increase in nickel concentrations, followed by a downward trend, suggests this occurrence is not an analytical or sampling artifact. See Section 6.3.3 for discussion of proposed additional data/information needs.

\subsection{Anions}

Anions are analyzed by the ion chromatography method. Well 299-W27-2 has higher concentrations of chloride as compared to other wells in the network. Selected anion concentration plots are presented 
in Figures 4.8 to 4.10. The upgradient well 299-W26-7 has the highest nitrate concentrations (see Figure 4.10). Also, nitrate concentrations are covariate with chromium concentrations in wells 299-W26-7, 299-W26-9, 299-W26-10 and 299-W26-12 (Figure 4.11 to 4.14). As noted in Section 4.2, the co-variate structure is consistent with the release of $416.4 \mathrm{~L}$ (110 gal) of synthetic double-shell tank waste in the S-10 facility in September 1983. The peak concentration was observed in December 1997 in wells 299-W26-7, 299-W26-10, and 299-W26-12, but peak concentrations of chromium and nitrate were observed in January 1999 in well 299-W26-9. The distance between 299-W26-7 and 299-W26-9 is about $150 \mathrm{~m}$ (492 ft) (refer to Figure 6.1 for well locations). The groundwater flow rate using the distance and the timing of the peak chromium concentration from upgradient well 299-W26-7 to downgradient well 299-W26-9 is about $0.4 \mathrm{~m}(1.3 \mathrm{ft})$ per day. This estimate is consistent with the range of groundwater flow rate 0.053 to $2.55 \mathrm{~m}$ ( 0.17 to $8.4 \mathrm{ft}$ ) per day calculated using the Darcy equation for this facility (see Hartman et al. 2002, Table A.2).

\subsection{Exceedances of Maximum Contaminant Level}

The only exceedances of maximum contaminant levels occurred in the shallow upgradient well 299-W26-7 for hexavalent chromium, and in the deep well 299-W27-2 for carbon tetrachloride and nickel. Section 4.2 discusses the hexavalent chromium exceedance.

Carbon tetrachloride in well 299-W27-2 is believed to have come from an upgradient source. The source of high nickel concentration is unknown. This occurrence may be corrosion related.

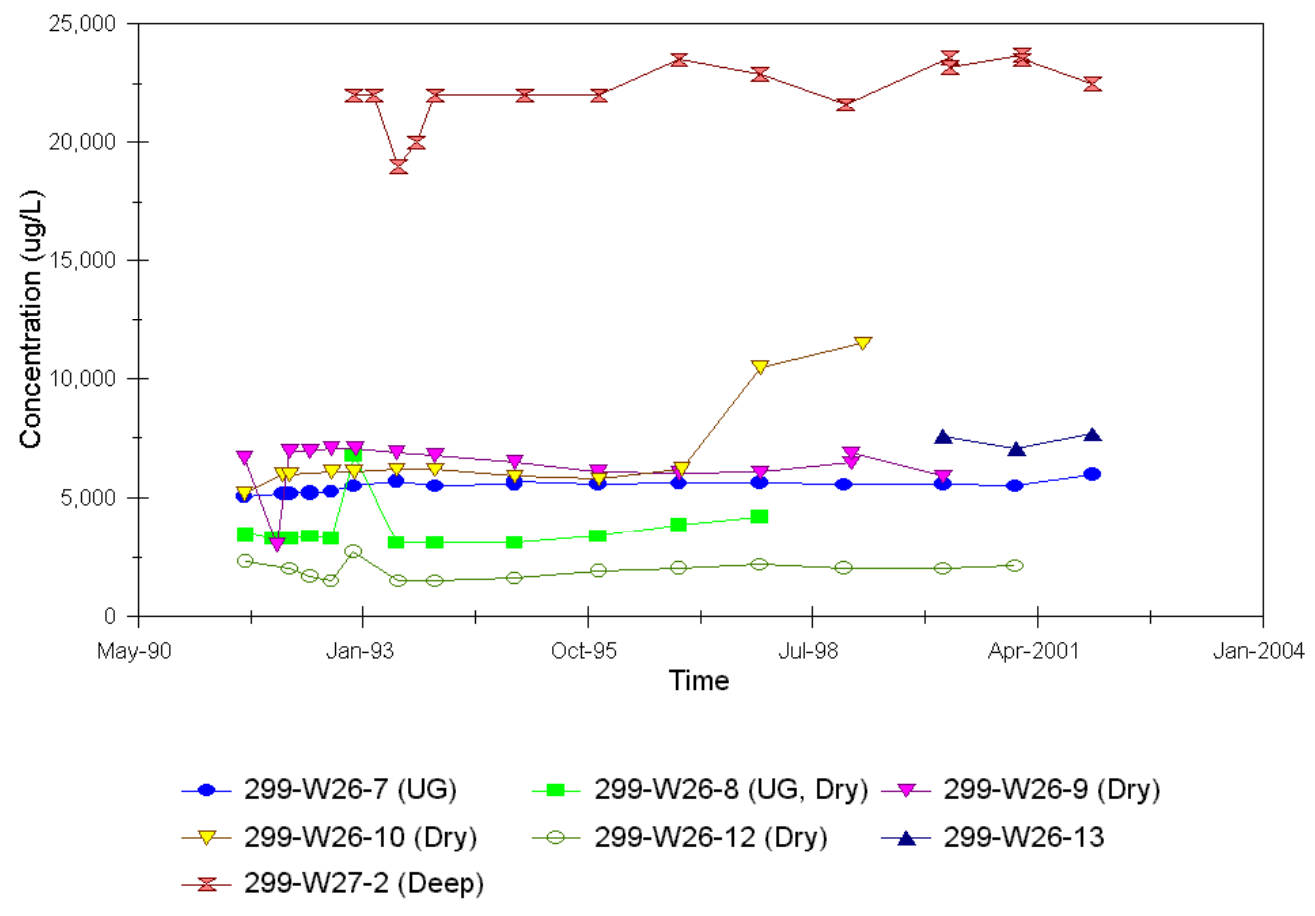

Figure 4.8. Chloride Concentrations versus Time 


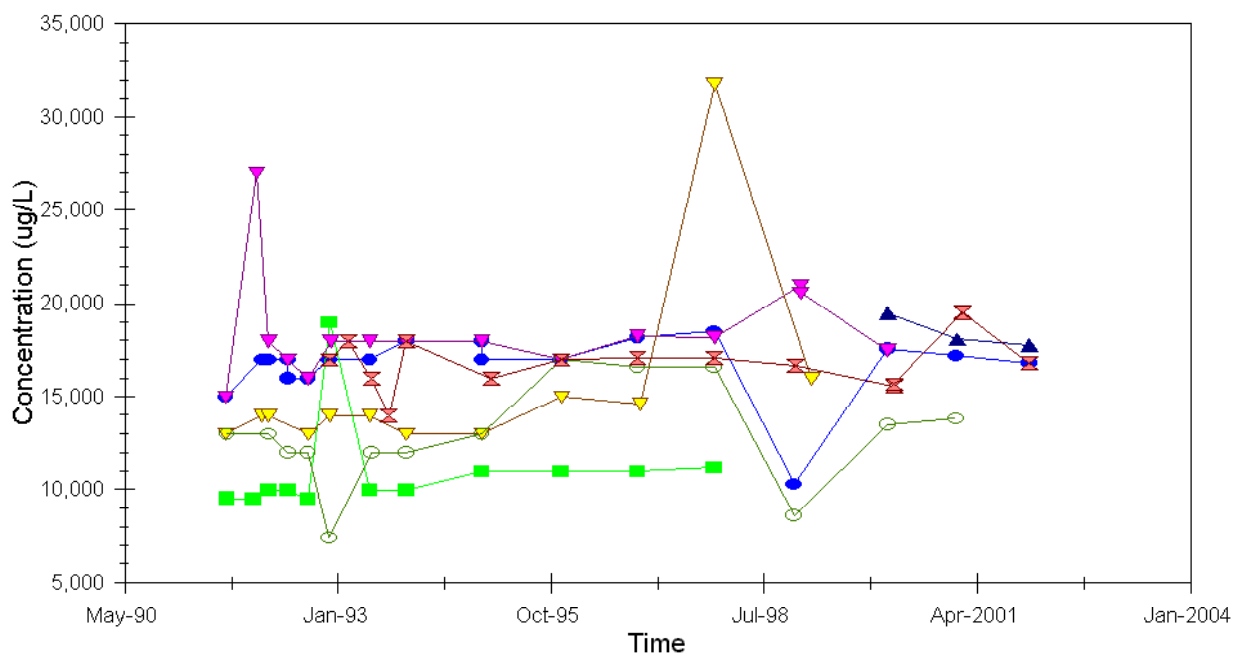

- 299-W26-7 (UG) $\quad-$ 299-W26-8 (UG, Dry) $\rightarrow$ 299-W26-9 (Dry)

$\rightarrow$ 299-W26-10 (Dry) $\odot$ 299-W26-12 (Dry) $\quad$ 299-W26-13

$\approx$ 299-W27-2 (Deep)

Figure 4.9. Sulfate Concentrations versus Time

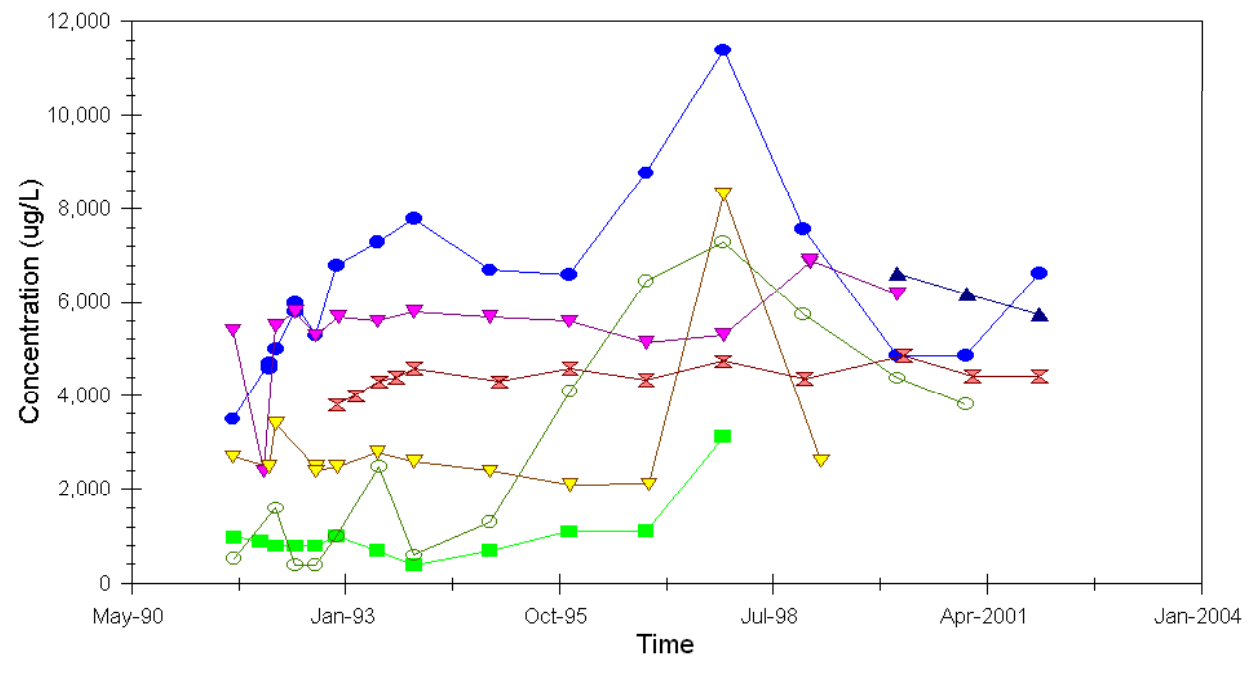

$$
\begin{aligned}
& - \text { - 299-W26-7 (UG) } \quad-\text { 299-W26-8 (UG, Dry) } \rightarrow \text { 299-W26-9 (Dry) } \\
& \rightarrow-299-W 26-10 \text { (Dry) } \odot \text { 299-W26-12 (Dry) } \leftarrow \text { 299-W26-13 } \\
& \mp \text { 299-W27-2 (Deep) }
\end{aligned}
$$

Figure 4.10. Nitrate Concentrations versus Time 


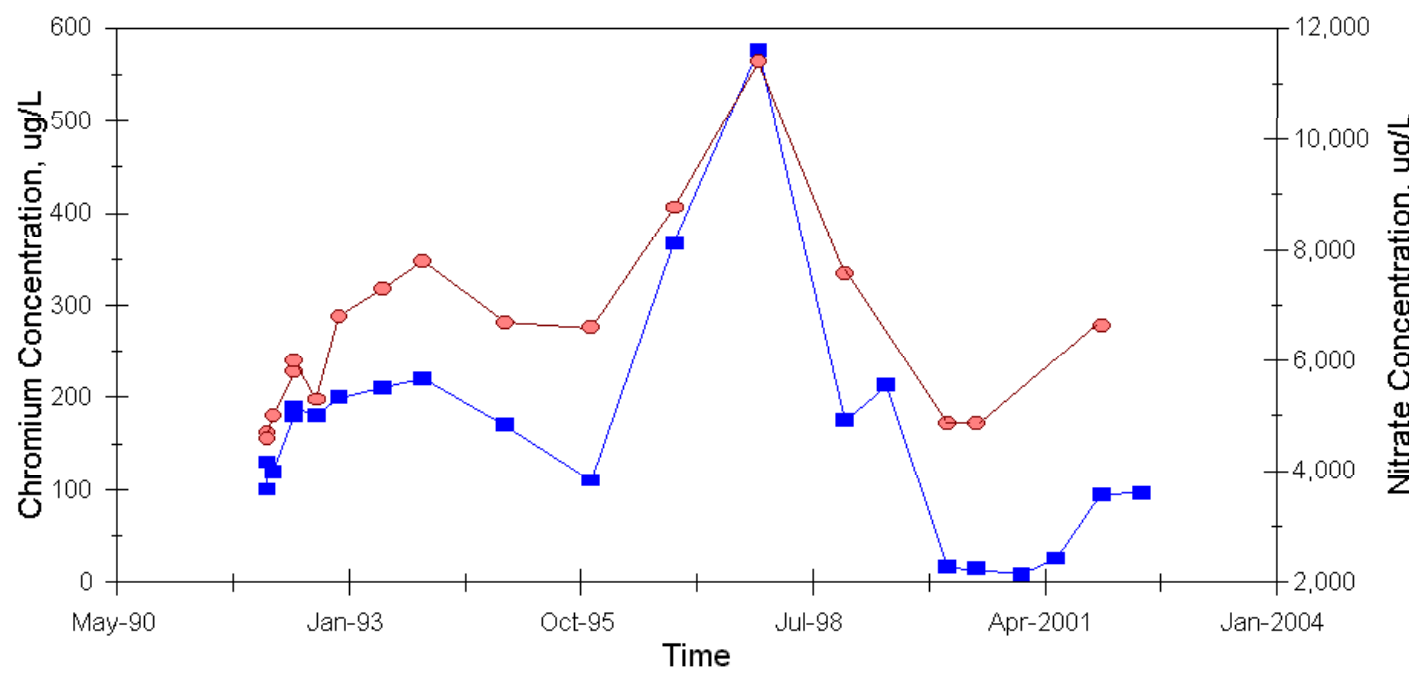

- Chromium $\multimap$ Nitrate

Figure 4.11. Chromium and Nitrate Concentrations in Well 299-W26-7

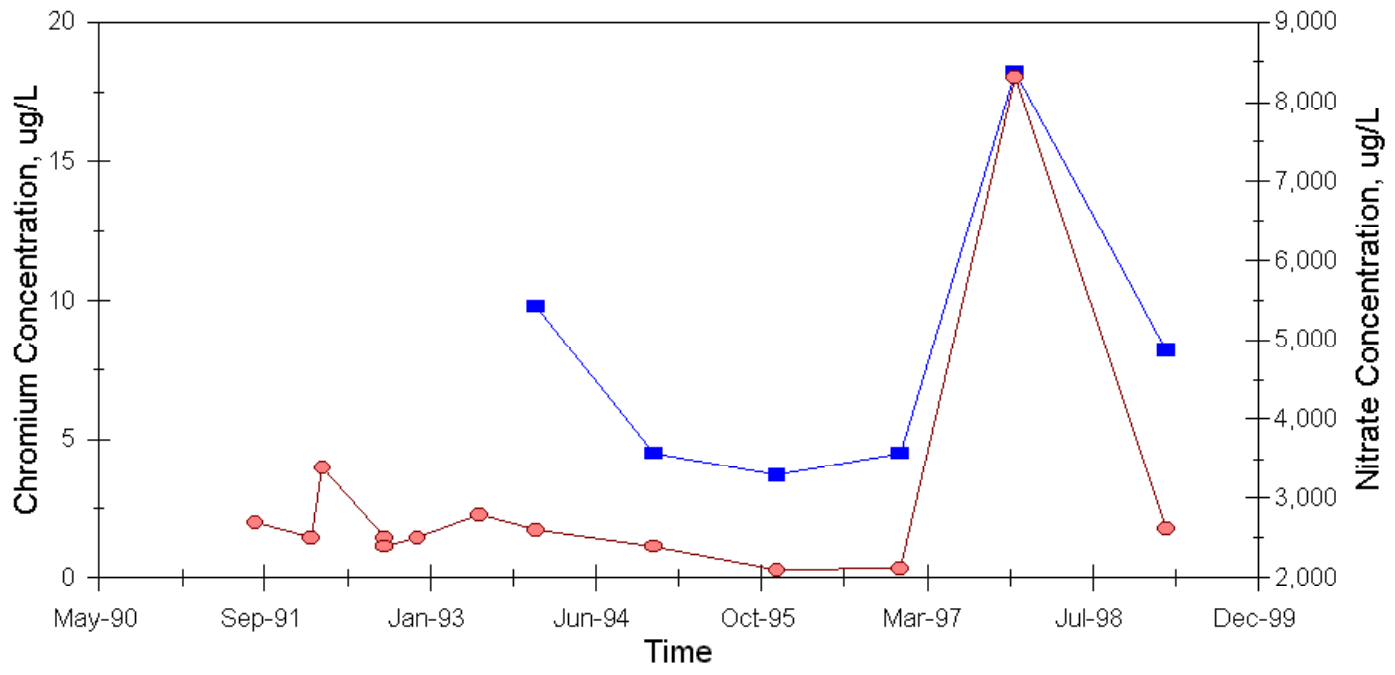

- Chromium $\rightarrow$ Nitrate

Figure 4.12. Chromium and Nitrate Concentrations in Well 299-W26-10 


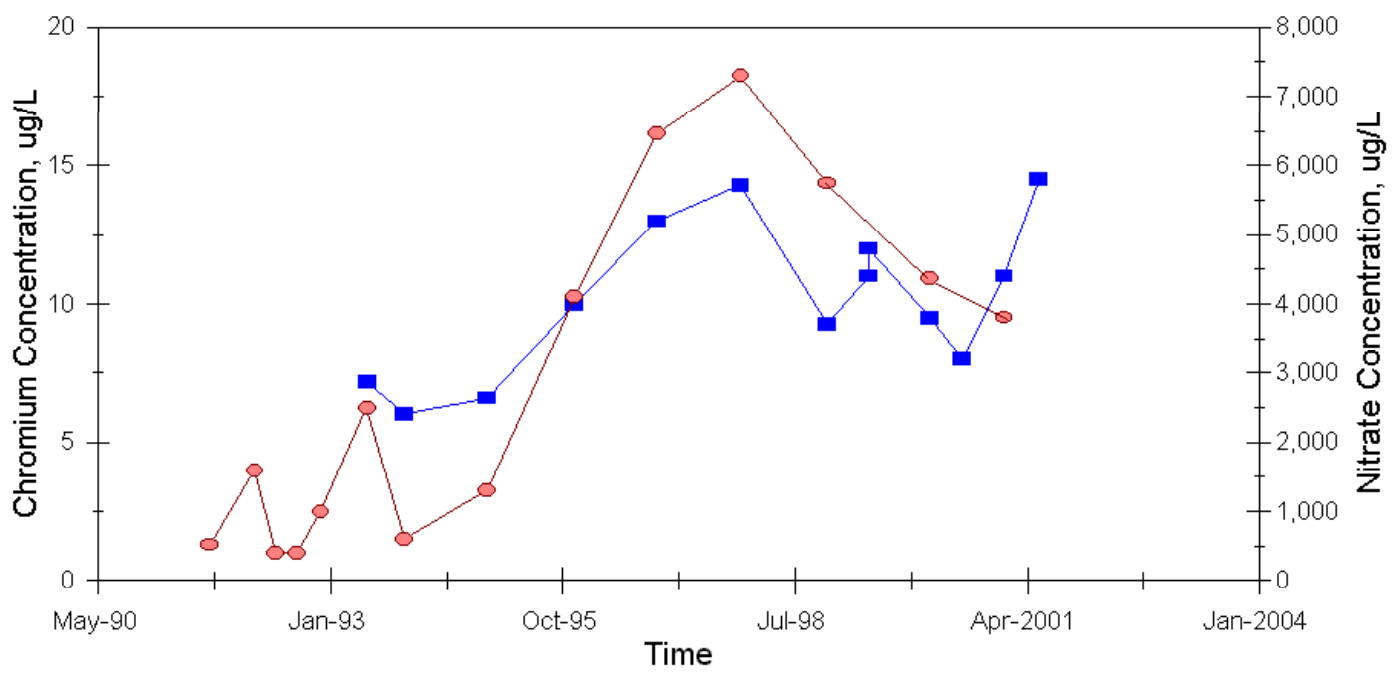

$\rightarrow-$ Chromium $\rightarrow$ Nitrate

Figure 4.13. Chromium and Nitrate Concentrations in Well 299-W26-12

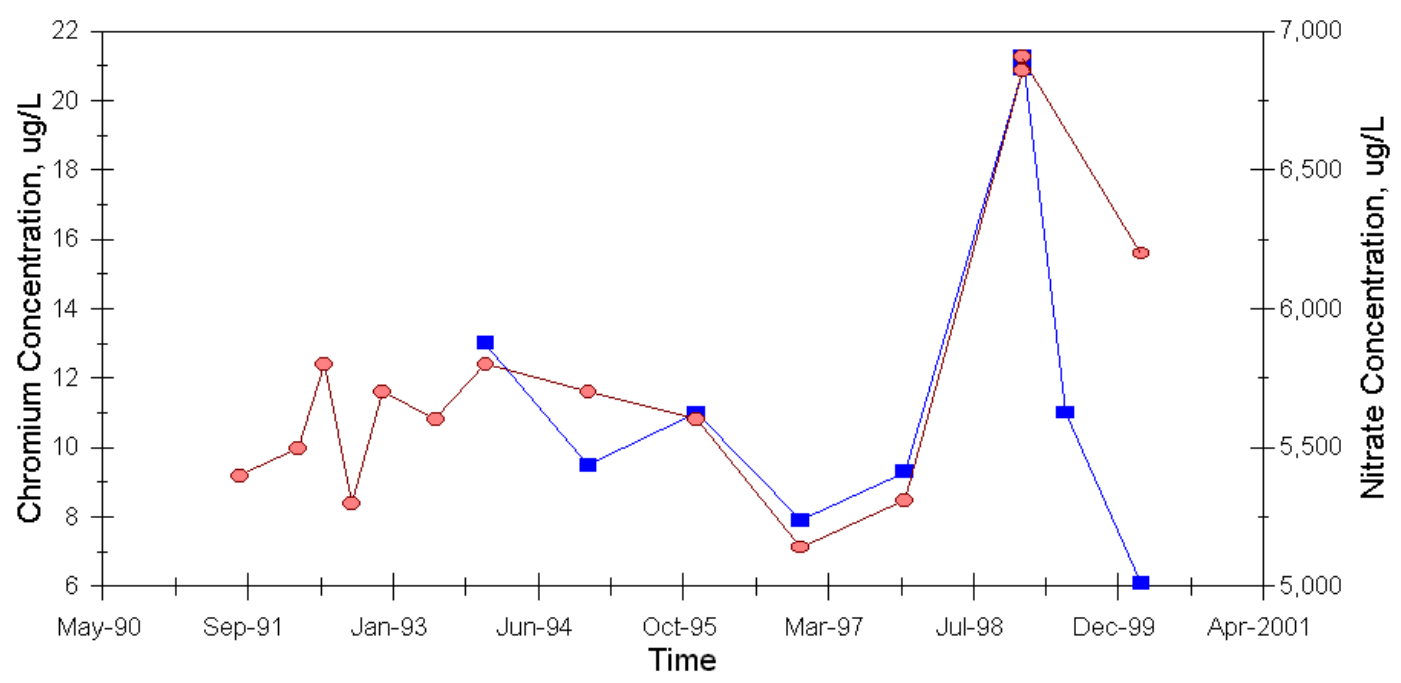

- Chromium $\multimap$ Nitrate

Figure 4.14. Chromium and Nitrate Concentrations in Well 299-W26-9 


\subsection{Conceptual Model}

A conceptual model of contaminant transport through the vadose zone beneath the 216-S-10 ditch and pond system is needed to assist in developing an appropriate and cost-effective monitoring plan. Development of the conceptualization begins with a summary of physical and chemical conditions at the disposal site and related assumptions.

- The large volume of water $\left[6.6 \times 10^{9} \mathrm{~L}\left(1.7 \times 10^{9}\right.\right.$ gal $\left.)\right]$ discharged to the S-10 facility was sufficient to wet the soil column down to groundwater beneath both the unlined ditch and the pond.

- Waste streams discharged to this facility were classified as neutral to basic, low ionic strength and low organic content (WHC 1990, Appendix C). These effluent chemical characteristics are favorable for sorption of certain heavy metals (see bullets below) by vadose zone sediment.

- Fine textured sedimentary layers allowed subsurface, lateral spreading beyond the boundary of the pond system. As a result, wastewater may have intersected both upgradient and downgradient monitoring wells.

- Mobile contaminants associated with residual wastewater pore fluid are distributed over the entire soil column beneath the ditch and pond. Wastewater transport time through the vadose zone to groundwater during the active discharge period was previously estimated to be 2.7 years at this facility (WHC 1990, Table B-1). Thus, mobile contaminants released during the operating period had more than adequate time to breakthrough to groundwater.

- Many of the contaminants of concern are assumed to be mobile (non adsorbed) because they are either anions (including the oxymetal anions; chromate, vanadanate, and arsenate) or are noncharged chemical species (volatile and non-volatile organics). Several divalent metals (barium, cadmium, copper, lead, mercury, and nickel) are not expected to be mobile unless complexing agents were present. For purposes of this analysis, it is assumed the divalent metals were free to interact with and to be tightly bound to vadose zone sediment and are, thus, unlikely to break through to groundwater.

- Adjacent (upgradient), past-practice disposal sites (e.g., 216-S-17 pond which was in operation from October 1951 to March 1954) no longer have an effect on groundwater beneath the S-10 facility.

- There is no surface barrier to natural infiltration. An average net natural infiltration rate of $10 \mathrm{~cm}$ (3.9 in.) per year is assumed for the surface covering of coarse sand and sparse vegetation [located in a recharge zone designated as 5 to $10 \mathrm{~cm}$ (1.97 to 3.9 in.) per year]. Recharge of this magnitude through unvegetated, coarse-textured surfaces can result in an upper bound average vadose zone transport rate for moisture and non-adsorbing solutes of up to $2 \mathrm{~m}(72 \mathrm{ft})$ per year. 
Based on the hydrogeology of the site, operational history, and the assumptions and conditions as noted above, a schematic representation of contaminant transport through the vadose zone to groundwater was constructed as illustrated in Figure 5.1.

During operation, the conceptual model shows that saturated or semi-saturated flow conditions prevailed beneath the ditch and pond system. Contaminants from periodic releases migrated through the soil column to groundwater. Lateral spreading likely brought waste constituents to the upgradient well (299-W26-7). This accounts for the occurrence of chromium in this well.

The occurrence of chromium in groundwater at this facility appears to correlate with the release of potassium dichromate (hexavalent chromium) in chemical waste discharged to the ditch in September 1983 from a simulated double-shell tank waste associated with the Chemical Engineering Laboratory. While the quantity of this waste release was small [416.4 L (110 gal)] containing approximately $10 \mathrm{~kg}$ (22 lbs) of $\mathrm{K}_{2} \mathrm{Cr}_{2} \mathrm{O}_{7}{ }^{[2-]}$, it was apparently enough to be detected in groundwater monitoring wells a few years later. Also, the ratio of nitrate to chromium (as $\mathrm{Cr}$ ) in the source is 16 as compared to a ratio of about 20 observed during peak concentrations in well 299-W26-7 (i.e., observed peak date = December 1, 1997 , nitrate concentration $=11,4001 \mathrm{~g} / \mathrm{L}$ and chromium concentration $=5761 \mathrm{~g} / \mathrm{L})$. The close agreement in nitrate/chromium ratios tends to confirm the suspected source of the chromium and nitrate in the S-10 monitoring wells. The delay in time between the release event (September 1983) and the appearance of the chromium peak in monitoring well 299-W26-7 in December 1997 suggests the transport time through the vadose zone must be much slower than previously predicted at this waste site (WHC 1990).

Hexavalent chromium (filtered samples) in both upgradient and downgradient monitoring wells at the S-10 facility demonstrates that this mobile constituent reached groundwater and that this and other mobile contaminants are likely still distributed throughout the soil column (associated with the residual saturation). As previously noted in Section 1.0, this type of residual soil column source is subject to long-term drainage to groundwater in response to natural infiltration as the driving force. Unusual precipitation events (heavy snow fall followed by rapid melting) are assumed to enhance such transport.

The divalent metals (mercury, lead, nickel, zinc, copper, and cadmium) are assumed to be retained in the upper approximately $10 \mathrm{~m}(32.8 \mathrm{ft})$ of the soil column, based on waste stream chemistry, sorptive properties of these elements, and migration depth estimates in Hanford soil from previous studies (WHC 1990). Arsenic, chromium, selenium, and vanadium, are all assumed to be present as highly mobile oxymetal anions. If these metals were released in sufficient quantity, they should have been detected in wells. The presence of chromium in these wells is consistent with this expectation. The absence (nondetects) of the other mobile metals suggests their concentrations in effluent were too low to be detectable after mixing with the ambient groundwater. If they were not detected during the operational phase, it is unlikely they would be detected in the post shutdown or post closure period.

The organics also are shown as being mobile (i.e., as non-charged species). However, some organics such as polychlorinated biphenyls are not expected to be mobile. If the more mobile organics (e.g., alcohols, ketones, volatile organic halogens) were present in waste streams discharged to the pond system, they should have been present along with the hexavalent chromium. Their absence (non-detects) 


\section{A}

216-S-10 POND AND DITCH HYDROGEOLOGIC CROSS SECTION A-A'

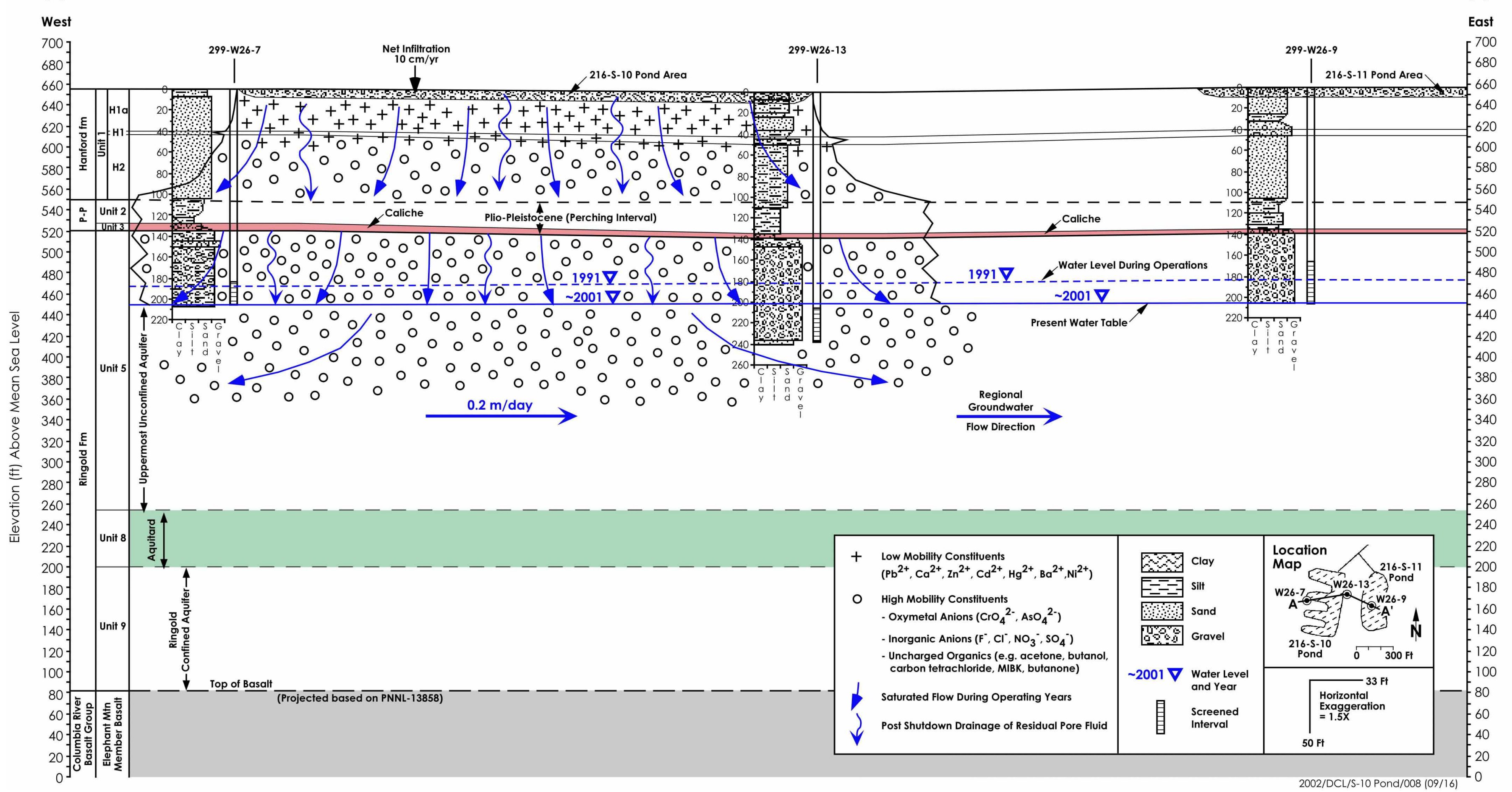

Figure 5.1. Conceptual Model of Infiltration of Effluent at the 216-S-10 Facility 
is taken as evidence that their effluent concentrations were either too low to be detectable after mixing with ambient groundwater, or they may have been present but were subject to biodegradation or volatization in the vadose zone. These and other considerations are used in Section 6.3.2 to arrive at a reasonable list of contaminants of concern for a revised sampling and analysis plan. 


\subsection{Groundwater Monitoring Program}

This section describes a groundwater monitoring program for the S-10 facility consisting of monitoring well network, target constituents, sampling and analysis protocol, and quality assurance and quality control. This plan replaces the existing RCRA interim status groundwater monitoring plan (Airhart et al. 1990). This new plan is expected to be effective until final status closure is obtained for the facility, which is set by the Tri-Party Agreement modification schedule to occur in 2006.

\subsection{Objectives of RCRA Monitoring}

The objectives of RCRA groundwater monitoring at the S-10 facility are:

- To detect, and assess existing or new sources of contamination to groundwater originating from the facility.

- To provide input to the corrective action process, if necessary, pursuant to WAC 173-303-646.

- To support closure of the RCRA regulated unit.

The ultimate goal is to design a technically sound and cost-effective monitoring program that is capable of protecting human health and the environment.

\subsection{Special Conditions at the S-10 Pond and Ditch}

The declining water table in the 200 West Area, especially in the vicinity of the S-10 facility, caused many RCRA-compliant wells to go dry. Initially, the RCRA groundwater monitoring network was composed of six compliant (WAC 173-160) groundwater monitoring wells installed in 1990 and 1991 (as-built diagrams are presented in the Appendix). Two upgradient wells (299-W26-7 and 299-W26-8) and three downgradient wells (299-W26-9, 299-W26-10, and 299-W26-12) monitored the upper 4.5 to $6 \mathrm{~m}$ (15 to $20 \mathrm{ft})$ of the uppermost aquifer. Another well, 299-W26-11, was completed in a perched water zone above the Plio-Pleistocene Unit 2 and 3 to monitor apparent perched effluent recharging to the aquifer. Depth to water in the perched zone was about $38 \mathrm{~m}(125 \mathrm{ft})$. However, when surface water discharges ceased in 1991, the perched water began receding. The water level within well 299-W26-11 dropped below the level of the well screen shortly after the surface water discharges ceased at the S-10 facility. Well 299-W27-2 was installed in 1992 and monitors the lower $3 \mathrm{~m} \mathrm{(10} \mathrm{ft)} \mathrm{of} \mathrm{the} \mathrm{uppermost}$ aquifer, just above the Unit 8. Well locations are shown in Figure 6.1.

Currently, only one of the original six upper aquifer monitoring wells, 299-W26-7, remains in service due to declining water levels (see Figure 3.6). With the exception of the vadose well, four wells (299-W26-8, 299-W26-9, 299-W26-10, and 299-W26-12) have gone dry, at an average rate of one well per year starting in early 1998; the current upgradient well 299-W26-7 is projected to go dry in 2003. Only one replacement well, 299-W26-13, has been added to the network (completed in January 2000) near the S-10 Pond (see Figure 6.1). Well 299-W26-13 was constructed with a 11-m (35-ft) well screen 


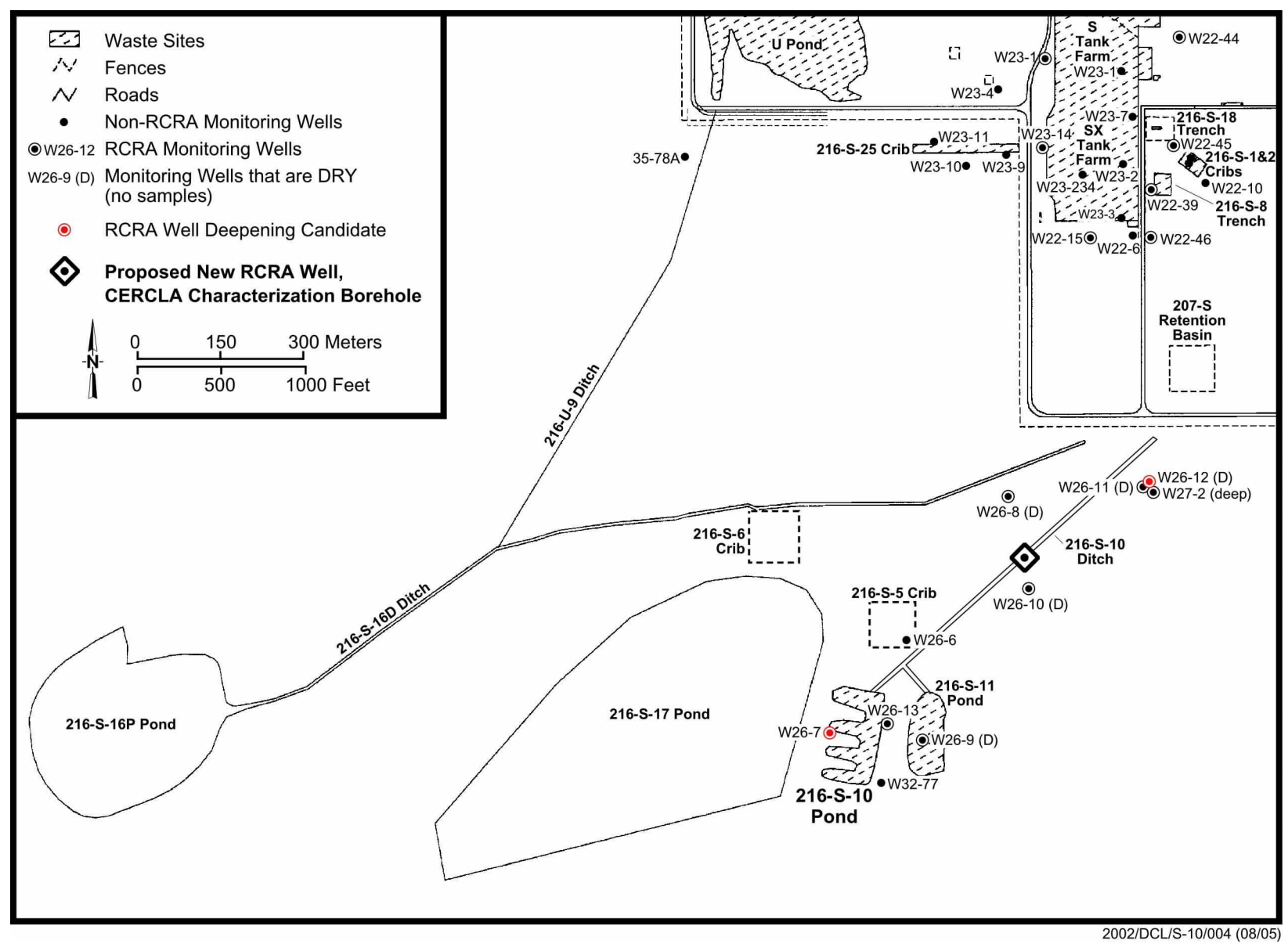

Figure 6.1. Well Location Map at the 216-S-10 Pond and Ditch

and is expected to remain active, i.e., will not go dry, during the closure period. As a result, the site currently has two wells (299-W26-7 and 299-W26-13) that monitor the top of the unconfined aquifer. Well 299-W27-2 monitors the bottom of the unconfined aquifer. Thus, the current network does not meet the minimum requirement of one upgradient and three downgradient wells to evaluate the possible site impact on the uppermost aquifer [40 CFR 265.91(a)(1) and (2)]. Ecology and DOE annually negotiate installation of future monitoring wells under Tri-Party Agreement milestone M-24-00.

\subsection{Sampling and Analysis Plan}

This section provides the revised sampling and analysis plan for the S-10 facility. A revised and reduced groundwater monitoring network is proposed using, in part, a new well-deepening technology to re-activate recent dry wells. Also, one CERCLA characterization borehole is identified as a candidate location for completion as a new RCRA well for addition to the network. This revised network will meet the minimum RCRA requirements for interim-status detection. 
A site-specific sampling constituent list is developed from a final list of contaminants of concern, identified under a CERCLA data quality objective process, which is refined by evaluating the constituents against a list of facility specific exclusion criteria and rationale. This reduced list of constituents meets the RCRA requirements for interim-status detection monitoring.

\subsubsection{Monitoring Well Network}

The well network (Table 6.1) was designed to:

- represent the quality of background groundwater in the uppermost aquifer near the facility that has not been affected by the S-10 facility [40CFR 265.91(a)(1)]

- assure that the number, locations, and depths of downgradient wells immediately detect any statistically significant amounts of hazardous (dangerous) waste or hazardous (dangerous) waste constituents that migrate from the S-10 facility to the uppermost aquifer.

Figure 6.1 provides the location of the previous and current RCRA groundwater monitoring well networks. Currently, only one upgradient well 299-W26-7, located near the west side of the S-10 pond, and one downgradient well, 299-W26-13, located just east of the S-10 pond monitor the facility for RCRA compliance. Also, there is one deep RCRA well, 299-W27-2, which monitors groundwater conditions at the base of the uppermost unconfined aquifer.

Groundwater monitoring at a RCRA interim status facility requires a minimum of one upgradient and three downgradient wells. The upgradient well will become unsampleable and go dry in 2003 if the water table continues to decline at the current rate. This will reduce the RCRA monitoring network for the S-10 facility to just one shallow downgradient well. The S-10 facility is expected to remain in interim status monitoring until 2006 at which time it will be closed in accordance with Tri-Party Agreement milestones.

Table 6.1. $\quad$ Revised Monitoring Wells for the 216-S-10 Pond and Ditch

\begin{tabular}{|c|c|c|c|c|}
\hline Well & $\begin{array}{c}\text { Hydrogeologic Unit } \\
\text { Monitored }\end{array}$ & Sampling Frequency & $\begin{array}{l}\text { Water-Level } \\
\text { Measurement }\end{array}$ & Well Standard \\
\hline 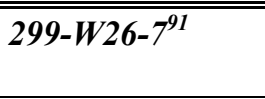 & $\begin{array}{l}\text { Deepened to top of } \\
\text { unconfined }\end{array}$ & Semiannual & Semiannual & RCRA \\
\hline $299-W 26-12^{91}$ & $\begin{array}{l}\text { Deepened to top of } \\
\text { unconfined }\end{array}$ & Semiannual $^{(\mathrm{a})}$ & Semiannual & RCRA \\
\hline 299-W26-1399 & Top of unconfined & Semiannual & Semiannual & RCRA \\
\hline NEW WELL $03^{(\mathrm{b})}$ & Top of unconfined & Semiannual & Semiannual & RCRA \\
\hline 299-W27-2 $2^{92(c)}$ & Base of unconfined & Semiannual & Semiannual & RCRA \\
\hline \multicolumn{5}{|c|}{$\begin{array}{l}\text { (a) Last sampled in fiscal year 2001; now dry. } \\
\text { (b) CERCLA characterization borehole to be completed as RCRA well. } \\
\text { (c) Used for supplemental information; no statistical evaluation. } \\
\text { Bold italic = Upgradient wells. } \\
\text { Superscript = Year of installation. } \\
\text { RCRA = Well constructed to RCRA standards. }\end{array}$} \\
\hline
\end{tabular}


Interim measures to bring the S-10 facility back into compliance with RCRA regulations can be achieved by using developing technology to deepen the wells and integrating activities with the ongoing CERLCA 200-CS-1 RI/FS investigation. Figure 6.1 also highlights proposed candidate wells which could be deepened to re-activate dry wells. If the well deepening technology is not successful, new replacement well locations will be evaluated and approved by DOE and Ecology through TPA milestone M-24-00.

The candidate wells for deepening, if the developing technology is successful, include the wells listed below:

- Well 299-W26-7 is a candidate because it is the current upgradient well that will be going dry and also because it has a historical trend of elevated chromium and nitrate as discussed previously (see Section 4).

- Well 299-W26-12, located at the north end of the S-11 ditch, is another candidate well and will provide coverage at the receiving/source input end of the facility.

In addition to these proposed two deepened wells, one new well is proposed near the center of the S-10 ditch (see Figure 6.1). The CERCLA RI/FS investigation being carried out during FY 2003 will construct a characterization borehole to the top of the water table in this location and plans to abandon the borehole after all sampling is completed (DOE/RL 2000). Significant cost saving can be realized and compliance can be achieved if this borehole could be drilled an additional $12 \mathrm{~m}$ (40 ft) and completed as a RCRA-compliant groundwater monitoring well. The CERCLA proposed location of the borehole will be either on the footprint or just downgradient of the backfilled and stabilized trench. This location can be used as a RCRA downgradient location. This well will be installed in accordance with WAC 173-160, groundwater monitoring well requirements, and will be sealed to eliminate the potential for migration of residual contamination down the borehole. RCRA requires at least three downgradient wells at the limit of the waste management area. The CERCLA borehole will be within, rather than at the limit of the waste management area, but since the S-10 facility is inactive, a well in this location will provide a more direct access to the aquifer directly below the ditch to allow monitoring of potential residual effluent draining from the vadose zone.

The proposed network for groundwater monitoring will be evaluated after it has been implemented to determine if it is adequate to provide groundwater monitoring for the remaining life of the S-10 facility and through the closure period.

\subsubsection{Constituent List and Sample Frequency}

This section provides the proposed groundwater constituent list and the rationale for deriving the sitespecific monitoring parameters for RCRA wells at the S-10 facility. Site-specific constituents of concern are derived using the final list of contaminants of concern developed under the data quality objectives process for the CERCLA 200-CS-1 Chemical Sewer Operable Unit. The CERCLA final list of contaminants of concern was developed by evaluating it against a list of exclusion criteria and rationale. BHI 
(1999) provides the details of this elimination process. Only contaminants that could affect groundwater quality are identified as RCRA site-specific constituents of in accordance with the following process:

- The final list of contaminants of concern developed under the data quality objective process for the 200-CS-1 Chemical Sewer Operable Unit, excluding radioactive constituents, is used as the base list. Radioactive constituents are excluded from the list because radionuclides are monitored under the authority of the Atomic Energy Act of 1954, as amended. Remaining constituents are listed in the first column of Table 6.2.

- From the base list, detection status (the number of detected analyses over the number of total valid analyses) for the network wells including wells that went dry (299-W26-8, 299-W26-9, 299-W26-10, 299-W26-12) and a deep well (299W27-2) are compiled. The result is shown in Table 6.2.

- From Table 6.2, those contaminants of concern that are either not detected (i.e., mercury, selenium, 1-butanol, 2-butanone, methyl isobutyl ketone or MIBK, 1,1,1 trichloroethane, 1,1,2 trichloroethane, xylene, polychlorinated biphenyls, shell E2342, and tributyl phosphate) or essentially non-detects (acetone, cadmium, copper, cyanide, phosphate, silver, sulfide, and toluene) are further eliminated.

- The maximum detected values for the consistently detected analytes for each well are compared with the Hanford Site groundwater background values (DOE/RL 1997, Table ES-1). Results are presented in Table 6.3.

- Constituents are further eliminated if the maximum detected values are less than the Hanford Site background values (i.e., arsenic, barium, and beryllium). Zinc is also eliminated because the only value that exceeded the background value of $48.91 \mathrm{~g} / \mathrm{L}$ is the maximum detected value of $211 \mathrm{~g} / \mathrm{L}$ from well 299-W26-10, which is believed to be an outlier (not consistent with historical trend).

- Total organic carbon is added in lieu of the semi-volatile organic group (e.g., diesel fuel, normal paraffin hydrocarbon, etc.), which is not analyzed as a constituent or group.

- Lead and nickel are eliminated because they are essentially all non-detects in the reported results for both old and new wells. Also, they are not expected to be mobile under discharge conditions at this facility (see discussion in Section 5). However, elevated nickel above the detection limit (and natural background) in deep well 299-W27-2 is the one exception. This occurrence may be corrosion related. Nickel has not been detected in the shallow wells, indicating the S-10 facility is not the source. Additional investigation may be necessary to confirm this speculation (see Section 6.3.3 for additional studies). If it is shown not to be an artifact of the well, then this constituent identified in the CERCLA process will be added to the routine monitoring list.

The remaining constituents are considered to be the site-specific constituents and are listed in Table 6.4. In addition to the site-specific constituents derived above, Table 6.4 also includes constituents that serve as general groundwater contamination indicator parameters, groundwater quality parameters, and other selected parameters to be analyzed under the $216-\mathrm{S}-10$ pond and ditch groundwater monitoring 
Table 6.2. Detection Status ${ }^{(a)}$ of Final List of Potential Contaminants of Concern at the 216-S-10 Ditch and Pond

\begin{tabular}{|c|c|c|c|c|c|c|c|}
\hline "Analyte List/Network ${ }^{(\mathrm{b})}$ & 299-W26-7 & 299-W26-8 & 299-W26-9 & 299-W26-10 & 299-W26-12 & 299-W26-13 & 299-W27-2 \\
\hline \multicolumn{8}{|c|}{$\begin{array}{c}\text { Metals (Filtered), 1g/L } \\
\end{array}$} \\
\hline Arsenic & $5 / 9$ & $1 / 7$ & $6 / 6$ & $4 / 7$ & $6 / 6$ & +-- & $2 / 4$ \\
\hline Barium & $17 / 19^{(\mathrm{c})}$ & $11 / 12^{(\mathrm{c})}$ & $11 / 14^{(\mathrm{c})}$ & $13 / 13$ & $10 / 14^{(\mathrm{c})}$ & $3 / 3$ & $15 / 15$ \\
\hline Beryllium & $4 / 19^{(c)}$ & $1 / 12^{(\mathrm{c})}$ & $5 / 14^{(\mathrm{c})}$ & $1 / 13$ & $1 / 14^{(\mathrm{c})}$ & $1 / 3$ & $5 / 15$ \\
\hline Cadmium & $1 / 19^{(\mathrm{c})}$ & $2 / 12^{(\mathrm{c})}$ & $1 / 14^{(\mathrm{c})}$ & $1 / 13$ & $0 / 14^{(\mathrm{c})}$ & $0 / 3$ & $0 / 15$ \\
\hline Chromium & $15 / 19^{(\mathrm{c})}$ & $5 / 12^{(\mathrm{c})}$ & $9 / 14^{(\mathrm{c})}$ & $4 / 13$ & $8 / 14^{(\mathrm{c})}$ & $6 / 6$ & $9 / 22$ \\
\hline Copper & $1 / 19^{(\mathrm{c})}$ & $3 / 12^{(\mathrm{c})}$ & $5 / 14^{(\mathrm{c})}$ & $3 / 13$ & $1 / 14^{(\mathrm{c})}$ & $1 / 3$ & $2 / 15$ \\
\hline Lead & $4 / 9$ & $4 / 7$ & $0 / 6$ & $2 / 7$ & $0 / 6$ & --- & $0 / 4$ \\
\hline Mercury & $0 / 9$ & $0 / 7$ & $0 / 6$ & $0 / 7$ & $0 / 6$ & --- & $0 / 4$ \\
\hline Nickel & $4 / 19^{(\mathrm{c})}$ & $3 / 12^{(\mathrm{c})}$ & $1 / 14^{(\mathrm{c})}$ & $0 / 13$ & $2 / 14^{(\mathrm{c})}$ & $2 / 3$ & $10 / 15$ \\
\hline Selenium & $0 / 9$ & $0 / 7$ & $0 / 6$ & $0 / 7$ & $0 / 6$ & --- & $0 / 4$ \\
\hline Silver & $0 / 19^{(\mathrm{c})}$ & $0 / 12^{(\mathrm{c})}$ & $0 / 14^{(\mathrm{c})}$ & $0 / 13$ & $1 / 14^{(\mathrm{c})}$ & $0 / 3$ & $1 / 15$ \\
\hline Vanadium & $12 / 19^{(c)}$ & $5 / 12^{(c)}$ & $13 / 14^{(\mathrm{c})}$ & $10 / 13$ & $12 / 14^{(\mathrm{c})}$ & $3 / 3$ & $13 / 15$ \\
\hline Zinc & $4 / 19^{(\mathrm{c})}$ & $3 / 12^{(\mathrm{c})}$ & $6 / 14^{(\mathrm{c})}$ & $5 / 13$ & $5 / 14^{(\mathrm{c})}$ & $2 / 3$ & $8 / 15$ \\
\hline \multicolumn{8}{|c|}{ Inorganics, $1 \mathrm{~g} / \mathrm{L}$} \\
\hline Ammonia & --- & --- & --- & --- & --- & $\begin{array}{l}--- \\
\end{array}$ & --- \\
\hline \begin{tabular}{|l|} 
Chloride \\
\end{tabular} & $19 / 19$ & $13 / 13$ & $15 / 15$ & $13 / 13$ & $14 / 14$ & $3 / 3$ & $15 / 15$ \\
\hline Cyanide & $0 / 1$ & $0 / 2$ & $1 / 2$ & $0 / 2$ & $1 / 2$ & --- & $0 / 1$ \\
\hline Fluoride & $18 / 18$ & $12 / 12$ & $14 / 14$ & $13 / 13$ & $13 / 13$ & $3 / 3$ & $15 / 15$ \\
\hline Nitrate $\left(\mathrm{As} \mathrm{NO}{ }^{-}\right)$ & $19 / 19$ & $13 / 13$ & $15 / 15$ & $13 / 13$ & $14 / 14$ & $3 / 3$ & $15 / 15$ \\
\hline Phosphate & $0 / 14$ & $1 / 12$ & $0 / 11$ & $0 / 11$ & $1 / 10$ & --- & $0 / 8$ \\
\hline Sulfate & $19 / 19$ & $13 / 13$ & $15 / 15$ & $13 / 13$ & $14 / 14$ & $3 / 3$ & $15 / 15$ \\
\hline Sulfide & $0 / 1$ & $0 / 1$ & $0 / 1$ & $0 / 1$ & $0 / 1$ & --- & $1 / 1$ \\
\hline Thiocyanate & --- & --- & --- & --- & --- & --- & --- \\
\hline $\mathrm{pH}$ & $131 / 131$ & $86 / 86^{(\mathrm{c})}$ & $95 / 95$ & $85 / 85^{(\mathrm{c})}$ & $99 / 99$ & $24 / 24$ & $76 / 76$ \\
\hline \multicolumn{8}{|c|}{$\begin{array}{ll}\text { Volatile Organics, } 1 \mathrm{~g} / \mathrm{L} \\
\end{array}$} \\
\hline Acetone & $1 / 12$ & 0/8 & $1 / 7$ & $0 / 9$ & $1 / 9$ & $1 / 2$ & $1 / 11$ \\
\hline 1-butanol & $0 / 11$ & $0 / 6$ & $0 / 6$ & $0 / 8$ & $0 / 8$ & $0 / 2$ & $0 / 11$ \\
\hline 2-butanone & $0 / 12$ & $0 / 8$ & $0 / 9$ & $0 / 9$ & $0 / 9$ & $0 / 2$ & $0 / 11$ \\
\hline Carbon tetrachloride & $4 / 15$ & $7 / 14$ & $1 / 9$ & $5 / 13$ & $4 / 11$ & $2 / 2$ & $14 / 14$ \\
\hline Chloroform & $4 / 15$ & $4 / 14$ & $2 / 9$ & $1 / 13$ & $10 / 11$ & $2 / 2$ & $10 / 14$ \\
\hline Decane & --- & --- & --- & --- & --- & --- & --- \\
\hline Dichloromethane & $1 / 15^{(\mathrm{c})}$ & $1 / 14$ & $0 / 9$ & $0 / 13^{(\mathrm{c})}$ & $0 / 13^{(c)}$ & $1 / 2$ & $1 / 14$ \\
\hline Ethanol & --- & --- & --- & --- & --- & --- & --- \\
\hline $\begin{array}{l}\text { Halogenated hydrocarbons } \\
\text { (TOX) }\end{array}$ & $20 / 112^{(\mathrm{c})}$ & $28 / 77^{(\mathrm{c})}$ & $15 / 83^{(c)}$ & $13 / 68^{(\mathrm{c})}$ & $25 / 84^{(c)}$ & $3 / 16$ & $39 / 65^{(c)}$ \\
\hline MIBK & $0 / 12^{(\mathrm{c})}$ & $0 / 8$ & $0 / 7$ & $0 / 9$ & $0 / 9$ & $0 / 2$ & $0 / 11$ \\
\hline Propanol & --- & --- & --- & --- & --- & --- & --- \\
\hline Toluene & $0 / 15$ & $1 / 14$ & $0 / 9$ & $0 / 13$ & $0 / 11$ & $0 / 2$ & $0 / 14$ \\
\hline $1,1,1$ trichloroethane & $0 / 15$ & $0 / 14$ & $0 / 9$ & $0 / 13$ & $0 / 11$ & $0 / 2$ & $0 / 14$ \\
\hline $1,1,2$ trichloroethane & $0 / 15$ & $0 / 14$ & $0 / 9$ & $0 / 13$ & $0 / 11$ & $0 / 2$ & $0 / 14$ \\
\hline Xylene & $0 / 15$ & $0 / 14$ & $0 / 9$ & $0 / 13$ & $0 / 11$ & $0 / 2$ & $0 / 14$ \\
\hline \multicolumn{8}{|c|}{ Semi-Volatile Organics, 1g/L } \\
\hline Diesel fuel & "--- & "--- & --- & $\begin{array}{c}-- \\
\end{array}$ & $\begin{array}{l}--- \\
\end{array}$ & $\begin{array}{ll}--- \\
\end{array}$ & "--- \\
\hline Kerosene & $0 / 1$ & $0 / 1$ & $0 / 1$ & $0 / 1$ & $0 / 1$ & --- & $0 / 1$ \\
\hline $\begin{array}{l}\begin{array}{l}\text { Normal paraffin } \\
\text { hydrocarbon }\end{array} \\
\end{array}$ & --- & --- & --- & --- & --- & --- & --- \\
\hline Paraffin hydrocarbon & --- & --- & --- & --- & --- & --- & --- \\
\hline $\begin{array}{l}\text { Polychlorinated biphenyls } \\
\text { (Aroclor-1242) }\end{array}$ & $0 / 1$ & $0 / 1$ & $0 / 1$ & $0 / 1$ & $0 / 1$ & --- & $0 / 1$ \\
\hline
\end{tabular}


Table 6.2. (contd)

\begin{tabular}{|c|c|c|c|c|c|c|c|}
\hline Analyte List/Network $^{(b)}$ & 299-W26-7 & 299-W26-8 & 299-W26-9 & 299-W26-10 & 299-W26-12 & 299-W26-13 & 299-W27-2 \\
\hline Shell E-2342 & $0 / 1$ & $0 / 1$ & $0 / 1$ & $0 / 1$ & $0 / 1$ & --- & $0 / 1$ \\
\hline Soltrol-170 & --- & --- & --- & --- & --- & --- & --- \\
\hline Tributyl phosphate & $0 / 1$ & $0 / 1$ & $0 / 1$ & $0 / 1$ & $0 / 1$ & --- & $0 / 1$ \\
\hline $\begin{array}{l}\text { (a) Table entry denotes t } \\
\text { analyte is not analyze } \\
\text { (b) Wells shown in bold } \\
\text { deep downgradient } \\
\text { (c) Invalid analysis excl }\end{array}$ & $\begin{array}{l}\text { total numb } \\
\text { e not dry. } 2 \\
\text { ed. }\end{array}$ & $\begin{array}{l}\text { f detected } \\
-\mathrm{W} 26-7 \text { is }\end{array}$ & pgradient & 1, 299-W26- & a downgradie & well, and 2 & $\mathrm{~W} 27-2$ is a \\
\hline
\end{tabular}

Table 6.3. Maximum Values and Hanford Site Groundwater Background Values for Detected Analytes at the 216-S-10 Pond and Ditch

\begin{tabular}{|c|c|c|c|c|c|c|c|c|}
\hline Analyte/Network ${ }^{(a)}$ & W26-7 & W26-8 & W26-9 & W26-10 & W26-12 & W26-13 & W27-2 & $\begin{array}{c}\text { Hanford } \\
\text { Background }^{(b)}\end{array}$ \\
\hline \multicolumn{9}{|c|}{ Metals (Filtered), 1g/L } \\
\hline Arsenic & 5.4 & 3.7 & 9.7 & 5.4 & 10 & $\begin{array}{c}--- \\
\end{array}$ & 3.3 & 11.8 \\
\hline Barium & 34 & 49 & 28.8 & 33.5 & 36 & 43.7 & 56.3 & 149 \\
\hline Beryllium & 1.8 & 0.61 & 0.73 & 0.42 & 0.7 & 1.4 & 1.4 & 3.38 \\
\hline Chromium & 576 & 29.1 & 61 & 18.2 & 14.3 & 12.2 & 10.2 & 3.17 \\
\hline Lead & $42^{(\mathrm{c})}$ & 7 & ND & 6.7 & ND & --- & $\mathrm{ND}$ & 1.3 \\
\hline Nickel & 33 & 19.6 & 26.1 & ND & 30 & 14.2 & 180 & 1.98 \\
\hline Vanadium & 53.6 & 40.6 & 59.2 & 43.3 & 41.4 & 32.8 & 40.9 & 19.3 \\
\hline Zinc & 7.13 & 28.7 & 20.7 & $211^{(\mathrm{c})}$ & 15.3 & 41.7 & 16 & 48.9 \\
\hline \multicolumn{9}{|c|}{ Inorganics, $1 \mathrm{~g} / \mathrm{L}$} \\
\hline Chloride & 6,000 & 6,800 & $7,7,100$ & 11,500 & 2,700 & 7,700 & 23,700 & 19,580 \\
\hline Fluoride & 900 & 800 & 800 & 800 & 1,200 & 550 & 900 & 1,298 \\
\hline Nitrate & 11,400 & 3,130 & 6,910 & 8,320 & 7,300 & 6,640 & 4,820 & 41,723 \\
\hline Sulfate & 18,500 & 19,000 & 27,000 & 31,800 & 17,000 & 19,500 & 19,600 & 54,950 \\
\hline $\mathrm{pH}$ & $7.15,8.39$ & $7.66,8.88$ & $7.01,8.44$ & $6.61,8.43$ & $7.04,8.54$ & $7.93,8.36$ & $7.29,8.40$ & $6.94,8.79$ \\
\hline \multicolumn{9}{|c|}{ Volatile Organics, 1g/L } \\
\hline Carbon tetrachloride & 0.4 & 4.8 & 0.58 & 2.3 & 6 & 1.5 & 6.4 & NA \\
\hline Chloroform & 0.47 & 0.81 & 0.4 & 2.3 & 6 & 0.59 & 0.68 & NA \\
\hline \multicolumn{9}{|c|}{ Semi-Volatile Organics, $1 \mathrm{~g} / \mathrm{L}$} \\
\hline Total Organic Carbon & 1,040 & 696 & 764 & 3,600 & 1,000 & 820 & 1,130 & 3,336 \\
\hline \multicolumn{9}{|c|}{\begin{tabular}{|l} 
(a) Well Prefix 299 omitted. Wells shown in bold are not dry. 299-W26-7 is an upgradient well, 299-W26-13 is a \\
downgradient well, and 299-W27-2 is a deep downgradient well. \\
(b) Source: Hanford Site Background: Part 3, Groundwater Background, DOE/RL (1997, Table ES-1). Metals were analyzed \\
using the ICP-MS method, which has lower detection limits than the ICP method used in RCRA sampling and analysis \\
program. Thus many of the maximum values shown are actually at or just above the detection limits for the ICP method \\
used even though the listed value is significantly higher than natural background as determined by ICP-MS. Lead and \\
nickel, for example, are essentially non-detect except for nickel in deep well 299-W27-2. Thus, lead and nickel area judged \\
to be non-detects or at or below the natural background, with the one exception noted. \\
(c) Suspected outlier. \\
NA = not applicable. \\
ICP = inductively coupled plasma \\
MS = mass spectrometry
\end{tabular}} \\
\hline
\end{tabular}


Table 6.4. Constituent List for the 216-S-10 Pond and Ditch

\begin{tabular}{||ll||}
\hline Indicator Parameters & \\
$\mathrm{pH}$ & \\
Total Organic carbon & Specific Conductance \\
Groundwater Quality Parameters $^{(\mathrm{b})}$ & Total Organic Halides \\
Chloride & \\
Manganese & Iron \\
Sodium & Phenols \\
Site-Specific Parameters & Sulfate \\
Chromium & \\
Other Selected Parameters & Vanadium \\
Alkalinity & \\
Carbon tetrachloride & Turbidity \\
Temperature & Chloroform \\
\hline (a) Subject to statistical evaluations described in Section 7.3. \\
(b) Sampled annually; all others sampled seminally. \\
\hline
\end{tabular}

program. The general contamination indicator parameters $(\mathrm{pH}$, specific conductance, total organic carbon, and total organic halides) and groundwater quality parameters (chloride, iron, manganese, phenols, sodium, and sulfate) are included to satisfy regulatory requirements stipulated in 40 CFR 265.92(b)(2) and 40 CFR 265.92(b)(3). Additional parameters, alkalinity, carbon tetrachloride, chloroform, turbidity, and temperature will be sought as indicators of sample quality and general aquifer/well background conditions. Groundwater will be sampled for all constituents on a semiannual basis except the groundwater quality parameters, which will be sought annually.

\subsubsection{Sampling and Analysis Protocol}

Monitoring of the S-10 facility is part of the Hanford Groundwater Monitoring Project. Procedures for groundwater sampling, documentation, sample preservation, shipment, and chain-of-custody requirements are described in PNNL or subcontractor manuals (e.g., ES-SSPM-001) and quality-affecting activities and documentation are included in the quality assurance plan. ${ }^{(a)}$ Samples generally are collected after three casing volumes of water have been purged from the well or after field parameters $(\mathrm{pH}$, temperature, specific conductance, and turbidity) have stabilized. For routine groundwater samples, preservatives are added to the collection bottles before their use in the field. Samples to be analyzed for metals are filtered in the field so that results represent dissolved metals.

Procedures for field measurements are specified in the subcontractor's or manufacturer's manuals. Analytical methods are specified in contracts with laboratories, and most are standard methods from Test Methods for Evaluating Solid Wastes, Physical/Chemical Methods (EPA 1986a). Alternative procedures meet the guidelines of SW-846, Chapter 10. Analytical methods are described in Hartman (2002).

(a) The Hanford Ground-Water Monitoring Project Quality Assurance Project Plan. QA Plan ETD-012, Rev. 2, December 2000. Pacific Northwest National Laboratory, Richland, Washington. 


\subsubsection{Quality Assurance and Quality Control}

The groundwater monitoring project's quality assurance/quality control (QA/QC) program is designed to assess and enhance the reliability and validity of groundwater data. The primary quantitative measures or parameters used to assess data quality are accuracy, precision, completeness, and the method detection limit. Qualitative measures include representativeness and comparability. Goals for data representativeness for groundwater monitoring projects are addressed qualitatively by the specification of well locations, well construction, sampling intervals, and sampling and analysis techniques in the groundwater monitoring plan for each RCRA facility. Comparability is the confidence with which one data set can be compared to another. The QC parameters are evaluated through laboratory checks (e.g., matrix spikes, laboratory blanks), replicate sampling and analysis, analysis of blind standards and blanks, and interlaboratory comparisons. Acceptance criteria have been established for each of these parameters in the project QA Plan ${ }^{(a)}$ based on guidance from the U.S. Environmental Protection Agency (OSWER-9950.1, EPA 1986b). When a parameter is outside the criteria, corrective actions are taken to prevent a future occurrence and affected data are flagged in the database.

\subsection{Additional Studies}

The occurrence of nickel in deep well 299-W27-2 is difficult to explain on the basis of existing information. If it is an artifact of the well and or sampling conditions, then there is no justification for including it in the constituent list for routine monitoring. If it is shown not to be an artifact of the well, then this constituent identified in the CERCLA process will be added to the routine monitoring list. Thus, an investigation of the nature of this occurrence is needed. The proposed general approach is described as follows.

If dissolved nickel is present in the aquifer, then periodic sampling during pumping should result in relatively constant concentrations of nickel. However, if there is a major change in concentration (high then declining rapidly with increasing volume removed) then a well-related effect is indicated. The proposed study involves collection of periodic samples for analysis of nickel during removal of up to six bore volumes, and continuous or discrete measurements of specific conductance, $\mathrm{pH}$, Eh and or dissolved oxygen. The latter parameters provide correlative information for assessing corrosion.

(a) The Hanford Ground-Water Monitoring Project Quality Assurance Project Plan. QA Plan ETD-012, Rev. 2, December 2000. Pacific Northwest National Laboratory, Richland, Washington. 


\subsection{Data Management, Evaluation, and Reporting}

This chapter describes how groundwater data are stored, retrieved, evaluated, and interpreted. Statistical evaluation methods and reporting requirements also are described.

\subsection{Data Management}

The contract laboratories report analytical results electronically. The results are loaded into the Hanford Environmental Information System (HEIS) database. Field-measured parameters are entered manually or through electronic transfer. Paper data reports and field records are considered to be the record copies and are stored at PNNL.

The data undergo a validation/verification process according to a documented procedure, as described in the project QA plan. ${ }^{\text {(a) }}$ QC data are evaluated against the criteria listed in the project QA plan and data flags are assigned when appropriate. In addition, data are screened by scientists familiar with the hydrogeology of the unit, compared to historical trends or spatial patterns, and flagged if they are not representative. Other checks on data may include comparison of general parameters to their specific counterparts (e.g., conductivity to ions), calculation of charge balances, and comparison of calculated versus measured conductivity. If necessary, the lab may be asked to check calculations or reanalyze the sample, or the well may be resampled.

\subsection{Interpretation}

After data are validated and verified, the acceptable data are used to interpret groundwater conditions at the site. Interpretive techniques may include:

- Hydrographs - graph water levels versus time to determine decreases, increases, seasonal, or manmade fluctuations in groundwater levels.

- Water-table maps - use water-table elevations from multiple wells to construct contour maps to estimate flow directions. Groundwater flow is assumed to be perpendicular to lines of equal potential.

- Trend plots - graph concentrations of constituents versus time to determine increases, decreases, and fluctuations. May be used in tandem with hydrographs and/or water-table maps to determine if concentrations relate to changes in water level or in groundwater flow directions.

- Plume maps - map distributions of chemical or radiological constituents areally in the aquifer to determine extent of contamination. Changes in plume distribution over time aid in determining movement of plumes and direction of flow.

(a) The Hanford Ground-Water Monitoring Project Quality Assurance Project Plan. QA Plan ETD-012, Rev. 2, December 2000. Pacific Northwest National Laboratory, Richland, Washington. 
- Contaminant ratios - can sometimes be used to distinguish between different sources of contamination.

\subsection{Statistical Evaluation}

The goal of RCRA detection monitoring is to determine if the S-10 pond and ditch has adversely impacted groundwater quality in the uppermost aquifer beneath the site. This is determined based on the results of a statistical test. According to 40 CFR 265.92 (and by reference of WAC 173-303-400[3]) the owner/operator of an interim-status hazardous waste facility must establish initial background concentrations for the contamination indicator parameters: specific conductance, $\mathrm{pH}$, total organic carbon, and total organic halogen. This has been done for the S-10 facility by obtaining at least four replicate measurements for each parameter from each well quarterly for 1 year during the first year of its operation. Data from the upgradient well(s) were used to determine the initial background arithmetic mean and variance. Subsequently, the background values were updated using more recent monitoring data from upgradient well 299-W26-7. The other upgradient well 299-W26-8 became dry after December 1997.

Monitoring data collected after the first year is compared with the background data to determine if there is an indication that contamination may have occurred. A t-test is required to make this determination (40 CFR 265.93[b]). A recommended method is the averaged replicate t-test method described in Appendix B of the RCRA Groundwater Monitoring Technical Enforcement Guidance Document (EPA 1986b). The averaged replicate t-test method for each contamination indicator parameter is calculated as:

$$
\mathrm{t}=\left(\overline{\mathrm{x}}_{\mathrm{i}}-\overline{\mathrm{x}}_{\mathrm{b}}\right) / \mathrm{S}_{\mathrm{b}} * \sqrt{1+1 / \mathrm{n}_{\mathrm{b}}}
$$

where $\mathrm{t}=$ test statistic

$$
\begin{aligned}
& \overline{\mathrm{x}}_{\mathrm{i}} \text { average of replicates from the } \mathrm{i}^{\text {th }} \text { monitoring well } \\
& \overline{\mathrm{x}}_{\mathrm{b}}=\text { background average } \\
& \mathrm{S}_{\mathrm{b}}=\text { background standard deviation } \\
& \mathrm{n}_{\mathrm{b}}=\text { number of background replicate averages. }
\end{aligned}
$$

A test statistic larger than the Bonferroni critical value, $t_{c}$, (i.e., $t>t_{c}$ ) indicates a statistically significant probability of contamination. These Bonferroni critical values depend on the overall falsepositive rate required for each sampling period (i.e., $1 \%$ for interim status), the total number of wells in the monitoring network, and the number of degrees of freedom $\left(n_{b}-1\right)$ associated with the background standard deviation. Because of the nature of the test statistic in the above equation, results to be compared to background do not contribute to the estimate of the variance. The test can be reformulated, without prior knowledge of the results of the sample (i.e., $\bar{x}_{i}$ ) to be compared to background, in such a way that a critical mean, CM, can be obtained:

$$
\mathrm{CM}=\overline{\mathrm{x}}_{\mathrm{b}}+\mathrm{t}_{\mathrm{c}} * \mathrm{~S}_{\mathrm{b}} * \sqrt{\left(1+1 / \mathrm{n}_{\mathrm{b}}\right)} \quad \text { (one tailed) }
$$




$$
\mathrm{CM}=\overline{\mathrm{x}}_{\mathrm{b}} \pm \mathrm{t}_{\mathrm{c}} * \mathrm{~S}_{\mathrm{b}} * \sqrt{\left(1+1 / \mathrm{n}_{\mathrm{b}}\right)} \quad \text { (two tailed) }
$$

Critical mean values for the S-10 facility are presented in Table 7.1. Note the critical means were calculated based on eight comparisons ( 2 wells $\mathrm{x} 4$ indicator parameters) to be made during each sampling event. Indicator parameters are evaluated at least annually to determine if the critical mean must be revised, and are listed in the annual groundwater monitoring report (Hartman et al. 2002).

If downgradient data exceed the critical mean, they are determined to be statistically significant increase from background. For $\mathrm{pH}$, a two-tailed critical mean (or critical range) is calculated and downgradient data beyond the range are considered to be statistically different from background. If a statistical exceedance is detected, the well will be resampled to determine if the originally detected increase (or $\mathrm{pH}$ decrease) was a result of laboratory or measurement error (verification sampling). If verification sampling confirms the exceedance, the owner/operator must notify Ecology within 7 days and submit a groundwater quality assessment plan within 15 days following the notification (40 CFR 265.93[d]). The goal of the assessment monitoring program is to determine if dangerous waste or dangerous waste constituents from the facility have entered the groundwater and, if so, to determine their concentration and the rate and extent of migration in groundwater (40 CFR 265.93[d]). An outline for the assessment plan is presented in Section 8.0.

\section{Table 7.1. Critical Means for 216-S-10 Pond and Ditch ${ }^{(a)}$ for FY2002 Comparisons}

\begin{tabular}{|c|c|c|c|c|c|c|c|}
\hline Constituent, unit & $\mathrm{N}$ & df & $t_{c}$ & $\begin{array}{c}\text { Average } \\
\text { Background }\end{array}$ & $\begin{array}{l}\text { Standard } \\
\text { Deviation }\end{array}$ & $\begin{array}{l}\text { Critical } \\
\text { Mean }\end{array}$ & $\begin{array}{c}\text { Upgradient/ } \\
\text { Downgradient } \\
\text { Comparison Value }\end{array}$ \\
\hline $\begin{array}{l}\text { Specific conductance, } \\
\mu \mathrm{S} / \mathrm{cm}\end{array}$ & 4 & 3 & 9.4649 & 269.375 & 3.282 & 304.1 & 304.1 \\
\hline Field $\mathrm{pH}$ & 4 & 3 & 11.9838 & 8.266 & 0.083 & {$[7.16,9.37]$} & {$[7.16,9.37]$} \\
\hline $\begin{array}{l}\text { Total organic carbon, }{ }^{(b, c)} \\
\mu \mathrm{g} / \mathrm{L}\end{array}$ & 4 & 3 & 9.4649 & 248.25 & 127.38 & $1,596.2$ & $1,596.2$ \\
\hline $\begin{array}{l}\text { Total organic halides, }{ }^{(\mathrm{c}, \mathrm{d})} \\
\mu \mathrm{g} / \mathrm{L}\end{array}$ & 4 & 3 & 9.4649 & 2.121 & 0.059 & 2.7 & 17.0 \\
\hline \multicolumn{8}{|c|}{$\begin{array}{l}\text { (a) Based on semiannual sampling events from June } 1999 \text { to January } 2001 \text { for upgradient well } 299-\mathrm{W} 26-7 \text {, } \\
\text { except for total organic carbon that was collected from December } 1998 \text { to January } 2001 . \\
\text { (b) Excluding unrepresentative measurement of } 1,040 \mu \mathrm{g} / \mathrm{L} \text { collected on December } 1998 \text { from well } \\
299-W 26-7 . \\
\text { (c) Critical means calculated from values reported below vendor specified method detection limit. } \\
\text { (d) Upgradient/downgradient comparison value is the most recently determined limit of quantitation. } \\
\mathrm{df}=\text { Degrees of freedom (n-1). } \\
\mathrm{n}=\text { Number of background replicate averages. } \\
\mathrm{NC}=\text { Not calculated. } \\
\mathrm{t}_{\mathrm{c}}=\text { Bonferroni critical t-value for appropriate df and } 8 \text { comparisons. }\end{array}$} \\
\hline
\end{tabular}




\subsection{Reporting}

Groundwater chemistry and water-level data are reviewed at least semiannually and are available in HEIS. The results of the statistical evaluation will be submitted to Ecology in RCRA quarterly reports and in the annual groundwater monitoring report of the Hanford Site Groundwater Monitoring Project (e.g., Hartman et al. 2002). In addition, groundwater analytical and hydrologic data from nearby facilities such as the single-shell tank farm S-SX Waste Management Area will be examined for results that may lend understanding to the hydrogeologic system and will be discussed in the Hanford Site annual groundwater report, as appropriate. This discussion will be accompanied by recommendations for modifications of the well network and/or constituent list, as necessary.

If groundwater monitoring data indicates there is statistically significant evidence of contamination (using method as described in Section 6.3) for one or more of the indicator parameters at any monitoring well at the compliance point, Ecology will be notified within 7 days of the finding specifying which indicator(s) have shown statistically significant evidence of contamination. The Hanford Site Groundwater Monitoring Project will develop and submit to Ecology a groundwater quality assessment plan within 15 days after the notification, or within the time agreed by Ecology in writing as long as the S-10 facility remains as an interim-status facility. Otherwise, an application for a permit modification to establish a compliance-monitoring program will be submitted to Ecology in 90 days, or within the time agreed by Ecology in writing, if the S-10 facility is brought into the Hanford Facility RCRA Permit (Ecology 1994, as amended) and is subject to final status groundwater monitoring requirements. 


\subsection{Outline for Assessment Monitoring Plan}

This section presents a basic outline for an assessment monitoring plan, as required by 40 CFR 265.93(a). An outline for the assessment plan is presented in Table 8.1. If a groundwater contamination indicator parameter at a downgradient well significantly exceeds the background value or if $\mathrm{pH}$ decreases and is confirmed by verification sampling, a detailed assessment plan will be prepared and submitted to Ecology (see Sections 7.3 and 7.4) and the facility monitoring will be elevated to assessment monitoring status. The assessment program must be capable of determining whether dangerous waste or dangerous waste constituents from the S-10 facility have entered the groundwater, their concentration, and the rate and extent of migration. The groundwater quality program will include the following elements:

- Description of the hydrogeologic conditions and identification of potential contaminant pathways.

- Description of the investigative approach for making first determination to decide if dangerous waste or dangerous waste constituents from the facility have entered the groundwater or if the exceedance was caused by other sources (false positive rationale).

- Description of the approach to fully characterize rate and extent of contaminant migration.

Table 8.1. Groundwater Quality Assessment Plan Outline

\begin{tabular}{||l||}
\hline Introduction \\
Conceptual Model \\
Hydrogeologic Setting \\
Waste Source Characteristics \\
Summary of Vadose and Groundwater Observations \\
Conceptualization of Contaminant Movement \\
Statement of the Problem or Key Issues \\
Decisions \\
Information Needs \\
Groundwater Flow Rate and Direction \\
Placement of Monitoring Wells \\
Extent of Contamination \\
Optimized Design for Data Acquisition \\
Constituents \\
Assessment Network \\
Sampling and Analytical Method \\
Data Evaluation \\
Quality Control and Quality Assurance \\
Implementation Schedule \\
Data Management and Reporting \\
References \\
\hline
\end{tabular}


- Number, locations, and depths of wells in the monitoring network.

- Sampling and analytical methods used.

- Data evaluation procedures.

- An implementation schedule.

The results of assessment determinations will be made as soon as technically feasible and a report of the findings will be sent to Ecology. The determinations will then be updated annually as required by 40 CFR 265.94(b). 


\subsection{References}

40 CFR 265. U.S. Environmental Protection Agency. "Interim Status Standards for Owners of Hazardous Waste Treatment, Storage, and Disposal Facilities." U.S. Code of Federal Regulations.

Airhart, S. P., J. V. Borghese, and S. Dudziak. 1990. Interim Status Groundwater Monitoring Plan for the 216-S-10 Pond and Ditch. WHC-SD-EN-AP-018, Rev. 0, prepared by Pacific Northwest Laboratory for Westinghouse Hanford Company, Richland, Washington.

Atomic Energy Act of 1954, as amended, 68 Stat. 919, 42 USC 2011 et seq.

BHI. 1999. Operable Unit DQO Summary Report. BHI-01276, Rev. 0, Bechtel Hanford, Inc., Richland, Washington.

BHI. 1995. S Plant Aggregate Area Management Study Technical Baseline Report. BHI-00176, Rev. 00, Bechtel Hanford, Inc., Richland Washington.

Bjornstad, B. N. 1984. Suprabasalt Stratigraphy Within and Adjacent to the Reference Repository Location. SD-BWI-DP-039, prepared by Rockwell Hanford Operations for the U.S. Department of Energy, Richland, Washington.

Bjornstad, B. N. 1985. "Late-Cenozoic Stratigraphy and Tectonic Evolution Within a Subsiding Basin, South-Central Washington," Geological Society of America, Abstract with Programs, Vol. 17, No. 7, p. 524.

Bjornstad, B. N. 1990. Geohydrology of the 218-W-5 Burial Ground, 200 West Area, Hanford Site. PNL-7336, Pacific Northwest Laboratory, Richland, Washington.

Kipp, K. L. and R. D. Mudd. 1973. Collection and Analysis of Pump Test Data for Transmissivity Values. BNWL-1709, Battelle Northwest Laboratory, Richland, Washington.

CERCLA - Comprehensive Environmental Response, Compensation, and Liability Act. 1980. Public Law 96-150, as amended, 94 Stat. 2767, 42 USC 9601 et seq.

Cole, C. R., S. K. Wurstner, M. P. Bergeron, M. D. Williams, and P. D. Thorne. 1997. Three-

Dimensional Analysis of Future Groundwater Flow Conditions and Contaminant Plume Transport in the Hanford Site Unconfined Aquifer-System: FY 1996 and 1997 Status Report. PNNL-11801, Pacific Northwest National Laboratory, Richland, Washington.

Connelly, M. P., B. H. Ford, and J. V. Borghese. 1992. Hydrogeologic Model for the 200 West Groundwater Aggregate Area. WHC-SD-EN-TI-014, Westinghouse Hanford Company, Richland, Washington.

DOE. 1987. 216-S-10 Ditch and Pond Preliminary Closure/Post Closure Plan. U.S. Department of Energy, Richland, Washington. 
DOE. 1988. Consultation Draft, Site Characterization Plan, Reference Repository Location, Hanford Site, Washington. DOE/RW-0164, Vol. 1, U.S. Department of Energy, Richland, Washington.

DOE/RL. 1997. Hanford Site Background: Part 3, Groundwater Background. DOE/RL-96-61, Rev. 0, U.S. Department of Energy, Richland Operations Office, Richland, Washington.

DOE/RL. 1999. 200 Area Remedial Investigation/Feasibility Study Implementation Plan -

Environmental Restoration Program. DOE/RL-98-28, Rev. 0, U.S. Department of Energy, Richland Operations Office, Richland, Washington.

DOE/RL. 2000. 200-CS-1 Operable Unit RI/FS Work Plan and RCRA TSD Unit Sampling Plan. DOE/RL-99-44, Rev. 0, U.S. Department of Energy, Richland Operations Office, Richland, Washington.

Ecology - Washington State Department of Ecology, U.S. Environmental Protection Agency, and U.S. Department of Energy. 1998. Hanford Federal Facility Agreement and Consent Order. Document No. 89-10, Rev. 5 (The Tri-Party Agreement), Olympia, Washington.

Ecology. 1994. Dangerous Waste Portion of the Resource Conservation and Recovery Act Permit for the Treatment, Storage, and Disposal of Dangerous Waste, as amended. Permit Number 7890008967, Effective September 28, 1994. Washington State Department of Ecology, Olympia, Washington.

EPA. 1986a. Test Methods for Evaluating Solid Waste: Physical/Chemical Methods, SW-846, Third Edition. Office of Solid Waste and Emergency Response, U.S. Environmental Protection Agency, Washington, D.C.

EPA. 1986b. RCRA Groundwater Monitoring Technical Enforcement Guidance Document. OSWER-9950.1, U.S. Environmental Protection Agency, Washington, D.C.

Fecht, K. R., S. P. Reidel, and A. M. Tallman. 1987. Paleodrainage of the Columbia River System on the Columbia Plateau of Washington State - A Summary, in Washington Division of Geology and Earth Resource Bulletin 77. Basalt Waste Isolation Project, Westinghouse Hanford Company, Richland, Washington.

GE. 1956. Tabulation of Radiological Liquid Waste Disposal Facilities. HW-43121, General Electric, Richland, Washington.

Graham, M. J., M. D. Hall, S. R. Strait, and W. R. Brown. 1981. Hydrology of the Separation Area. RHO-ST-42, prepared by Rockwell Hanford Operations for the U.S. Department of Energy, Richland, Washington.

Hartman, M. J., L. F. Morasch, and W. D. Webber (eds.). 2002. Hanford Site Groundwater Monitoring for Fiscal Year 2000. PNNL13788, Pacific Northwest National Laboratory, Richland, Washington.

Johnson, V. G. and C. J. Chou. 1999. RCRA Assessment Plan for Single-Shell Tank Waste Management Area S-SX at the Hanford Site. PNNL-12114, Pacific Northwest National Laboratory, Richland, Washington. 
Johnson, V. G. and D. G. Horton. 2000. Borehole Data Package for Wells 299-W22-48, 299-W22-49, and 299-W22-50 at Single-Shell Tank Waste Management Area S-SX. PNNL-13200, Pacific Northwest National Laboratory, Richland, Washington.

Last, G. V., B. N. Bjornstad, M. P. Bergeron, D. W. Wallace, D. B. Newcomer, J. A. Schramke, M. A. Chamness, C. S. Cline, S. P. Airhart, and J. S. Wilbur. 1989. Hydrogeology of the 200 Areas Low-Level Burial Grounds - An Interim Report. PNL-6820, Vol. 1, Pacific Northwest Laboratory, Richland, Washington.

Lindsey, K. A. 1995. Miocene- to Pliocene-Aged Suprabasalt Sediments of the Hanford Site, SouthCentral Washington. BHI-00184, Bechtel Hanford, Inc., Richland, Washington.

Lindsey, K. A., S. P. Reidel, K. R. Fecht, J. L. Slate, A. G. Law, and A. M. Tallman. 1994. "Geohydrologic Setting of the Hanford Site, South-Central Washington," In Geologic Field Trips of the Pacific Northwest, D. A. Swanson and Haugerud (eds.), Geological Society of America Annual Meeting, Department of Geological Sciences, University of Washington, Seattle, Washington, Chapter 1C, pp 1C-1 to $1 \mathrm{C}-16$.

Maxfield, H. L. 1979. 200 Areas Waste Sites. RHO-CD-673, handbook compiled by Rockwell Hanford Operations for the U.S. Department of Energy, Richland, Washington

Myers, C. W. and S. M. Price (eds.). 1981. Subsurface Geology of the Cold Creek Syncline. RHO-BWI-ST-14, Rockwell Hanford Operations, Richland, Washington.

RCRA - Resource Conservation and Recovery Act. 1976. Public Law 94-580, as amended, 90 Stat. 2795, 42 USC 6901 et seq.

RHO. 1979. Handbook 200 Area Waste Sites. RHO-CD-798, Vols. II and III, Rockwell Hanford Operations, Richland, Washington.

Tallman, A. M., K. R. Fecht, M. C. Marratt, and G. V. Last. 1979. Geology of the Separation Areas, Hanford Site, South-Central Washington. RHO-ST-23, Earth Sciences Group Research Department, Rockwell International, Richland, Washington.

Thorne, P. D., M. A. Chamness, F. A. Spane, Jr., V. R. Vermeul, and W. D. Webber. 1993. ThreeDimensional Conceptual Model for the Hanford Site Unconfined Aquifer System, FY93 Status Report. PNL-8971, Pacific Northwest Laboratory, Richland, Washington.

Thorne, P. D. and D. R. Newcomer. 1992. Summary and Evaluation of Available Hydraulic Property Data for the Hanford Site Unconfined Aquifer System. PNL-8337, Pacific Northwest Laboratory, Richland, Washington.

WAC 173-160. Minimum Standards for Construction and Maintenance of Wells. Washington Administrative Code, Olympia, Washington. 
WAC 173-303-400. Interim Status Facility Standards. Washington Administrative Code, Olympia, Washington.

WAC 173-303-646. Corrective Action. Washington Administrative Code, Olympia, Washington.

WHC. 1990. Liquid Effluent Study Final Project Report. WHC-EP-0367, prepared by Westinghouse Hanford Company for the U.S. Department of Energy Richland, Washington.

Williams, B. A. and D. B. Barnett. 1993. Borehole Completion Data Package for the 216-S-10 Facility, CY-1992. WHC-SD-EN-DP-052, Westinghouse Hanford Company, Richland, Washington.

Williams, B. A., B. N. Bjornstad, R. Schalla, and W. D. Webber. 2000. Revised Hydrogeology for the Suprabasalt Aquifer System, 200-East Area and Vicinity, Hanford Site, Washington. PNNL-12261, Pacific Northwest National Laboratory, Richland, Washington.

Williams, B. A., B. N. Bjornstad, R. Schalla, and W. D. Webber. 2002. Revised Hydrogeology for the Suprabasalt Aquifer System, 200- West Area and Vicinity, Hanford Site, Washington. PNNL-13858, Pacific Northwest National Laboratory, Richland, Washington.

Wurstner, S. K., P. D. Thorne, M. A. Chamness, M. D. Freshley, and M. D. Williams. 1995. Development of a Three-Dimensional Ground-Water Model of the Hanford Site Unconfined Aquifer System: FY 1995 Status Report. PNL-10886, Pacific Northwest Laboratory, Richland, Washington. 
Appendix

Well Construction and Completion Summaries 


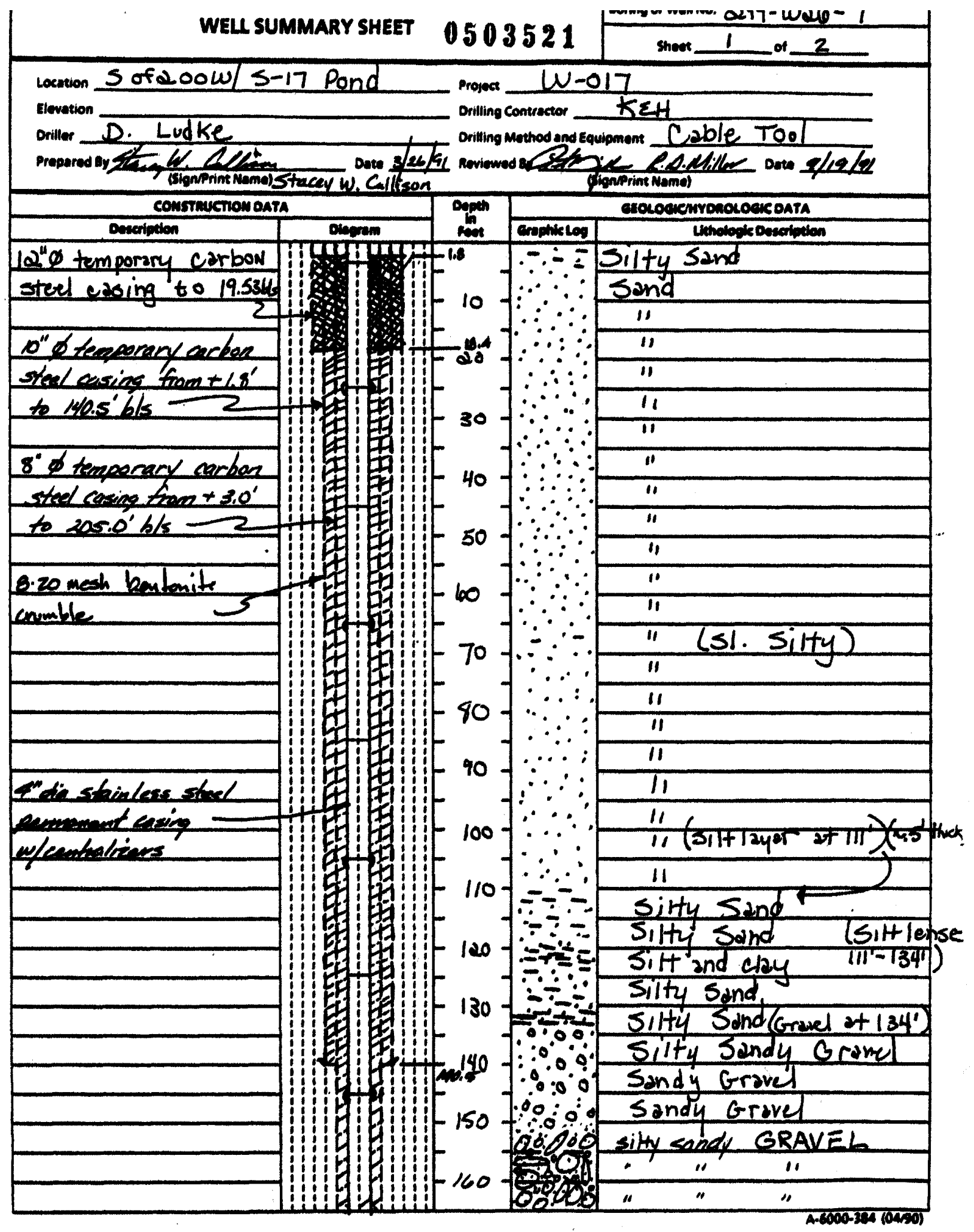




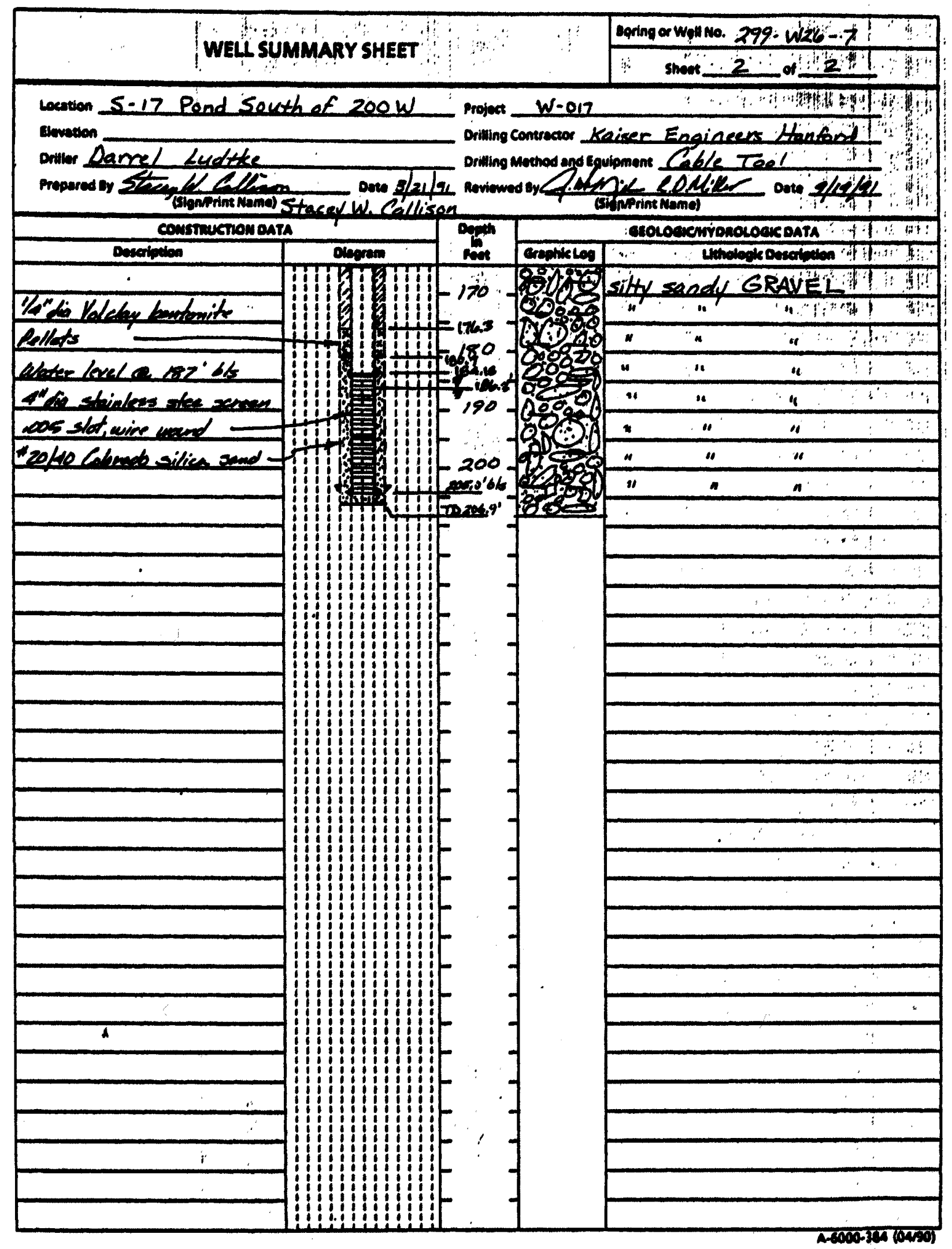




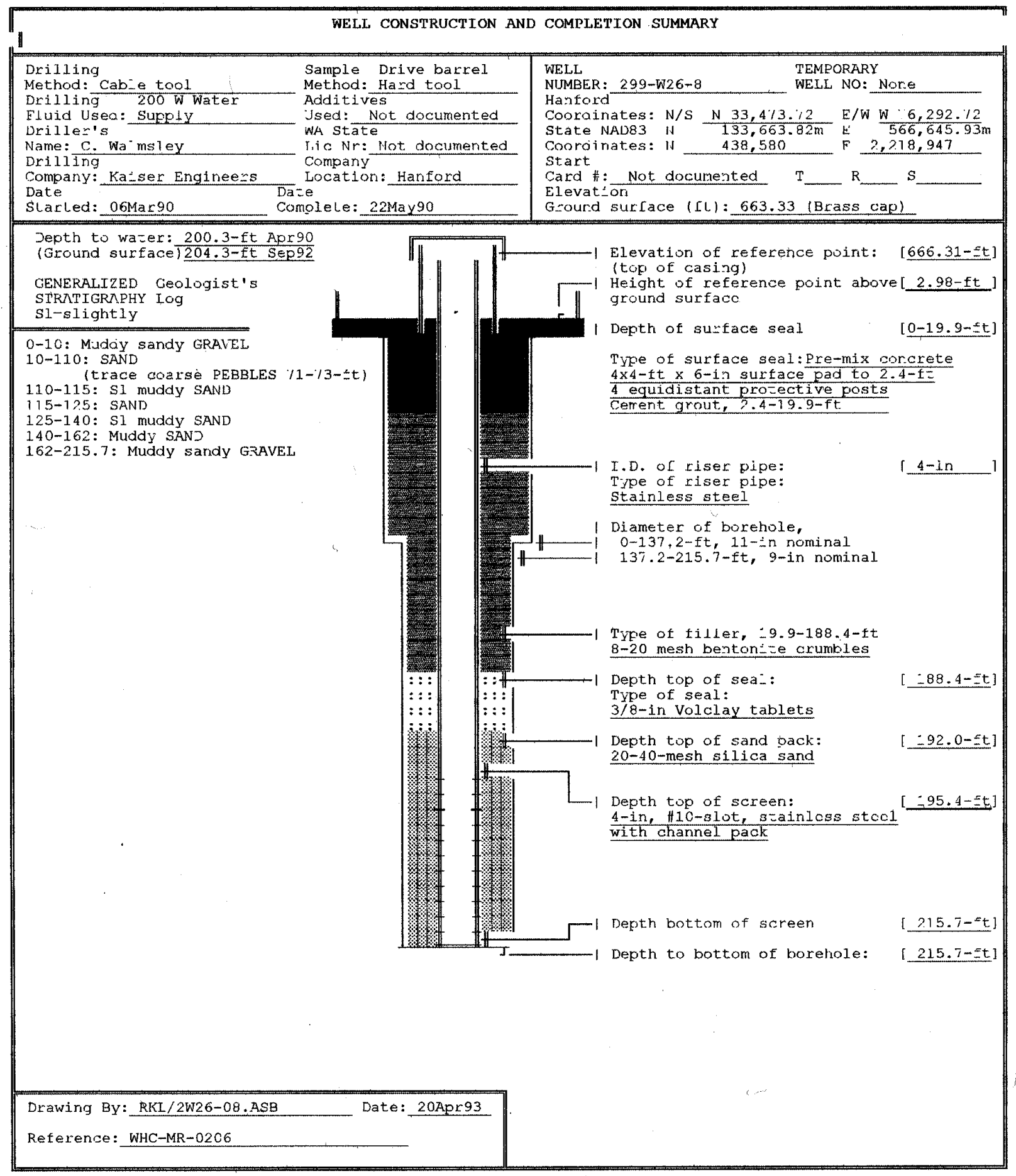


SUMNARY OF CONSTRUCTION DATA AND FIELD OBSERVATIONS RESOURCE PROTECTION WELL - 299-W26-8

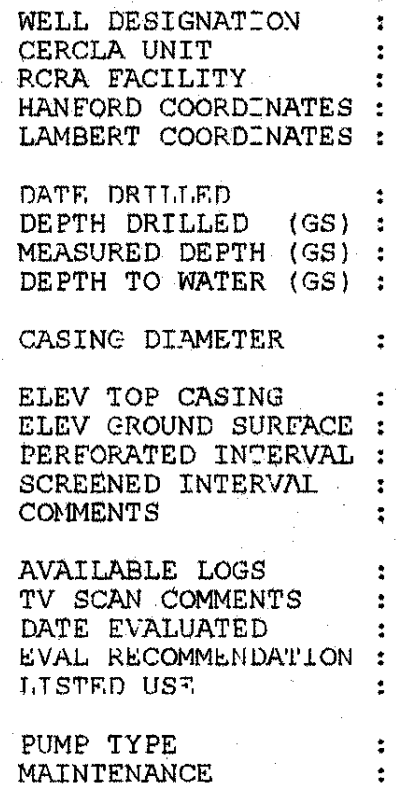

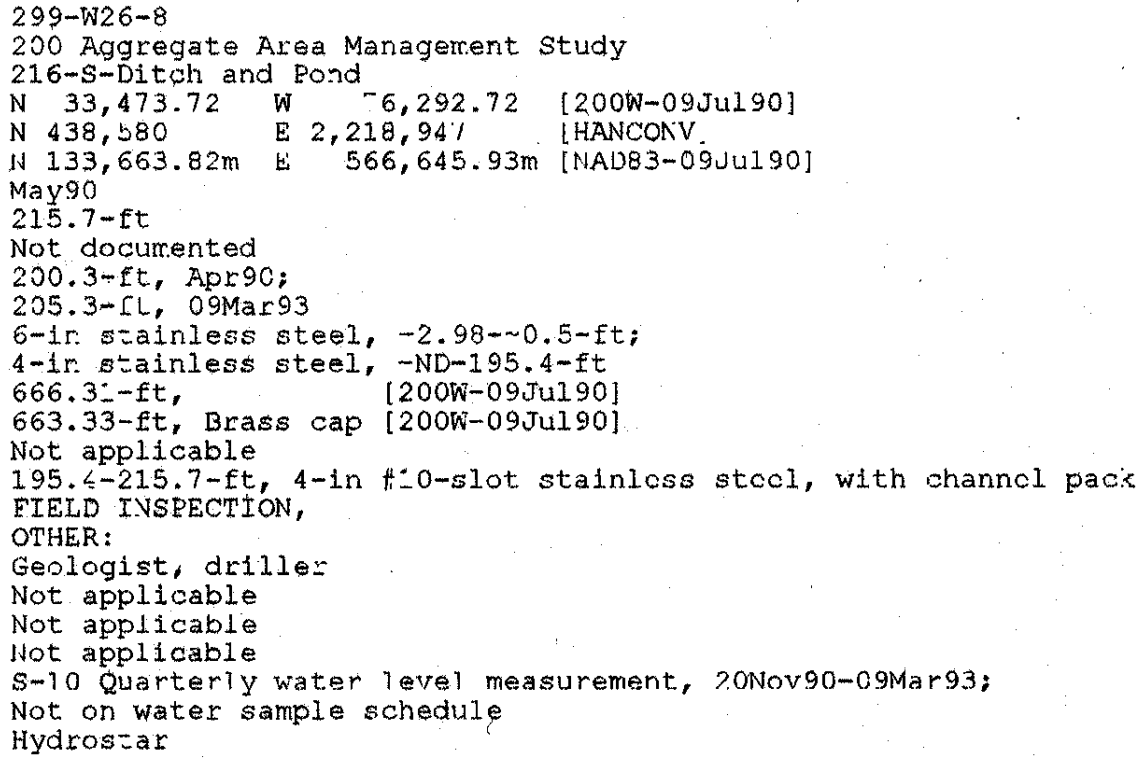




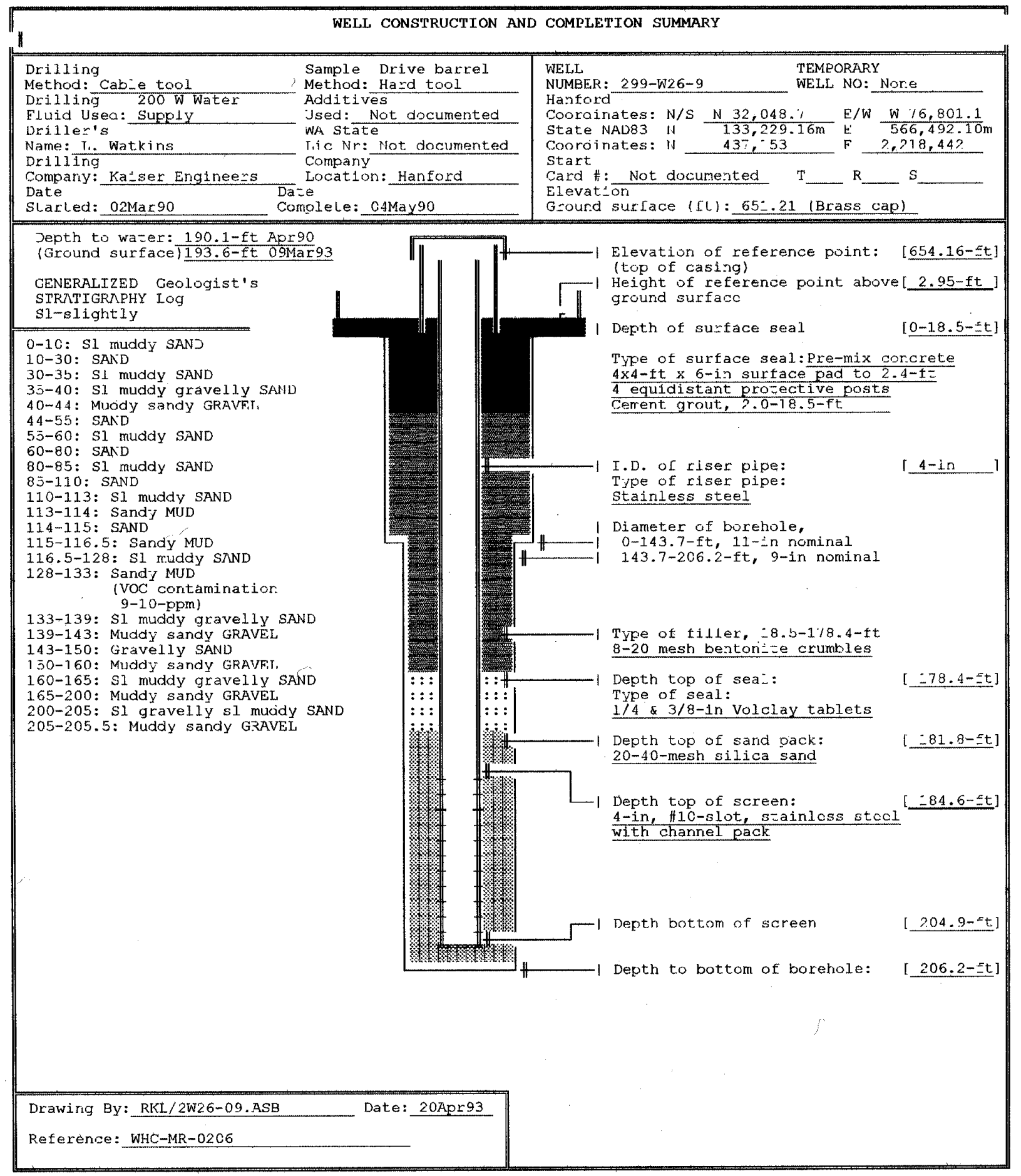




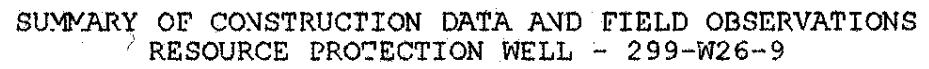

WELI DESIGNATZON

CERCLA UNTT

RCRA EACILITY

HANEORD COORD NATES :

LAMBERT COORDENATES :

DATF: DRTT,T.FID

DEPTH DRILLED (GS) :

MEASURED DEPTH (GS\} :

DEPTH TO WATER (GS) :

CASINE DIAMETER

ELEV TOP CASING ELEV GROUND SUREACE : PEREORATED INOERVAI : SCREENED INTERVAI

COMMENTS

AVAILABLE IOGS TV SCAN COMMENTS DATE EVALUATED EVAL RECOMMENDAILLON TTSTF, USF,

PUMP TYPE

MAINTENANCE
299-W26-9

200 Aggregate Area Managerent Study

216-S-Ditch and Pond

$N \quad 32,048.7$ W $-6,801.1 \quad$ [200W-09Ju190]

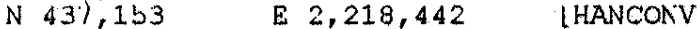

N $133,229.16 \mathrm{~m}$ E $566,492.10 \mathrm{~m}$ [NADB3-0.9Ju190]

May 90

$206.2-1 t$

Not documented

190.1-ft, Apr $9 \mathrm{C}$

$193.6-[L, 09 M a r 93$

6-ir. stainless steel, $-2.95-\sim 0.5-f t$;

4-ir. scainless steel, -ND-184.6-ft

654.16-ft, [200W-09Ju190]

$651.2:-f t$, Brass cap [200W-09Ju190]

Not applicable

184.6-204.9-ft, 4-in $H^{*}$-0-slot stainloss stcol, with channol pack FIELD INSPECTION, OTHER:

Geologist, drille:

Not applicable

Not applicable

Not applicable

s-10 Quarterly water level measurement, 7.0Nov90-C9Mar93;

Not on water sample schedule

Hydrostar 


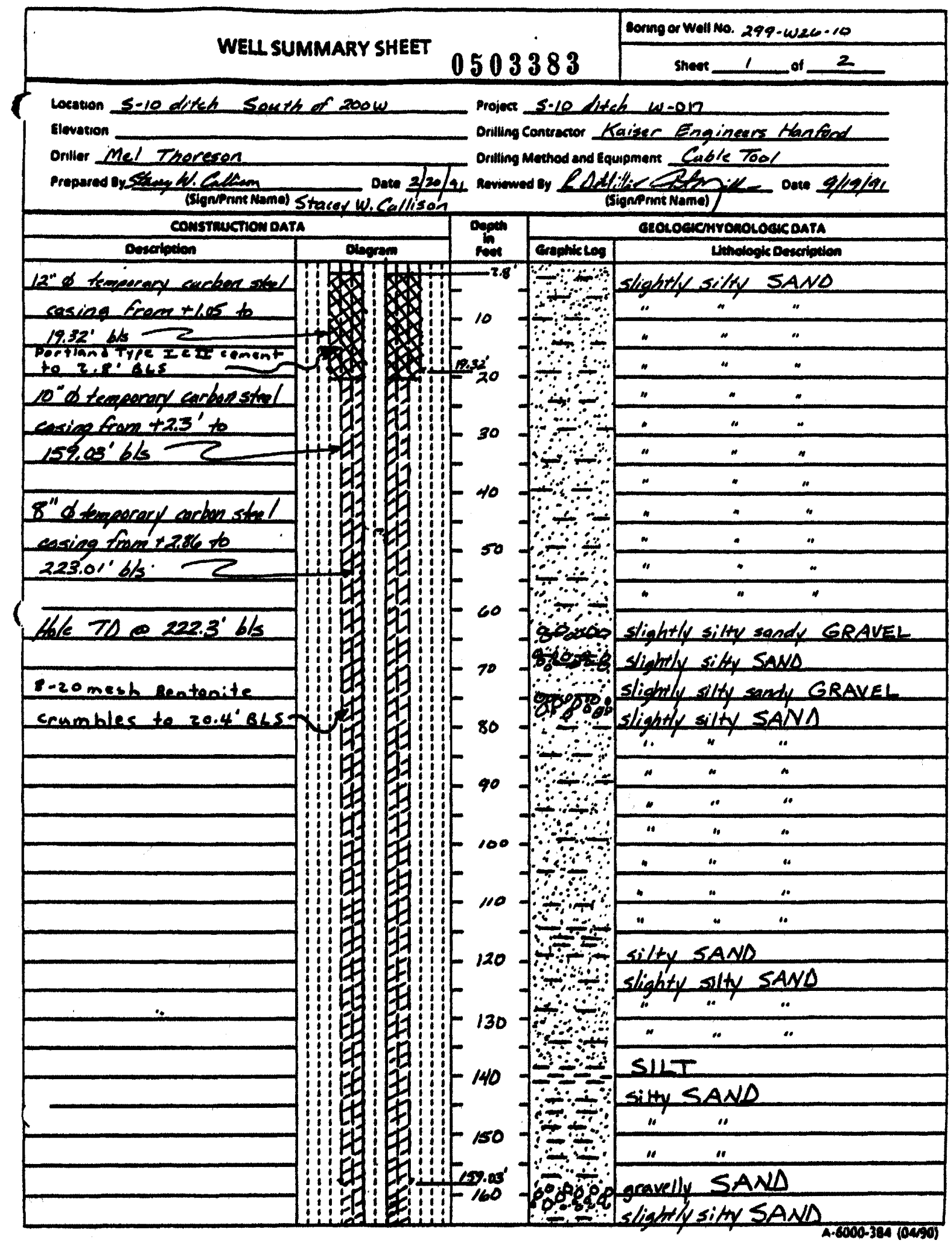




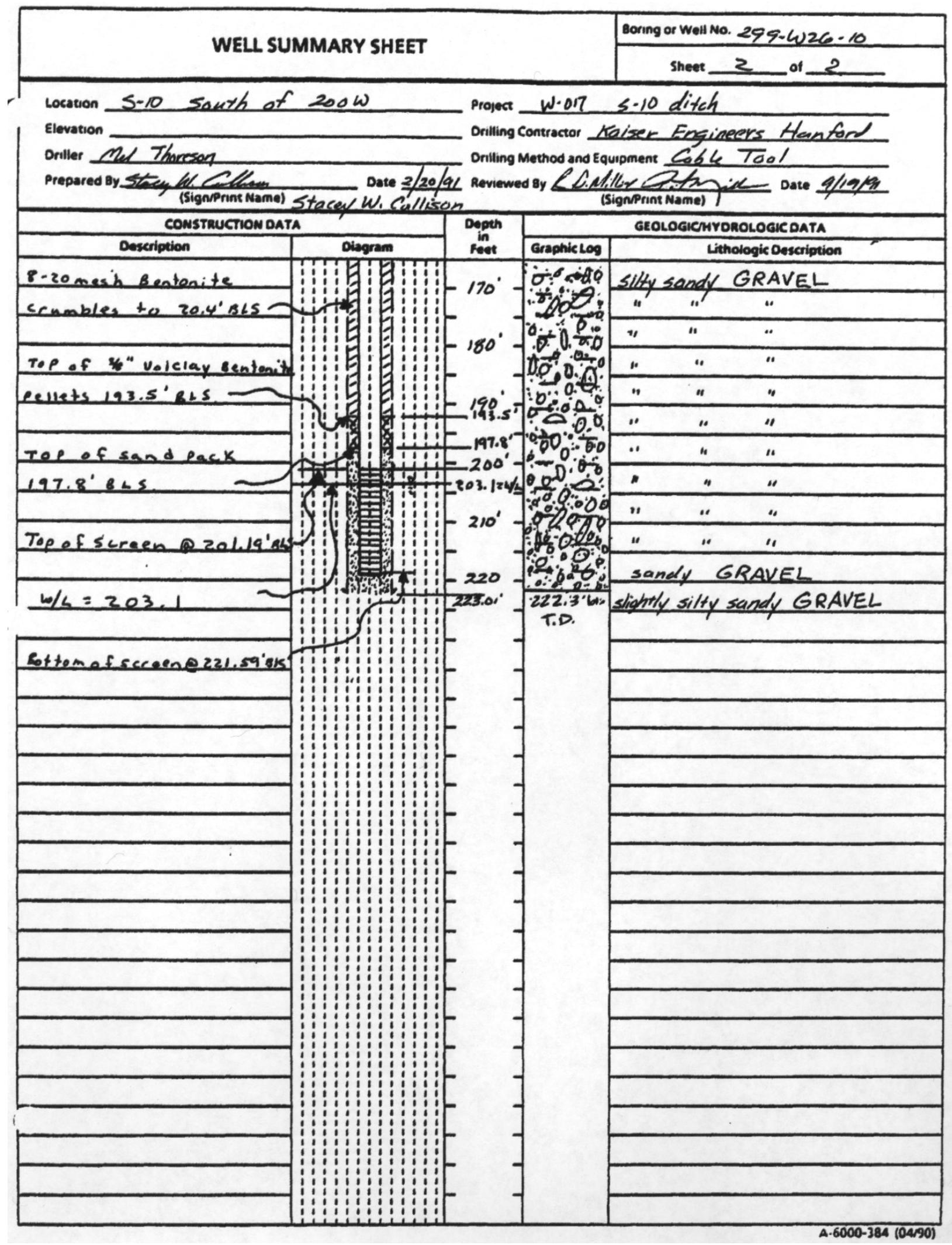

A. 8 


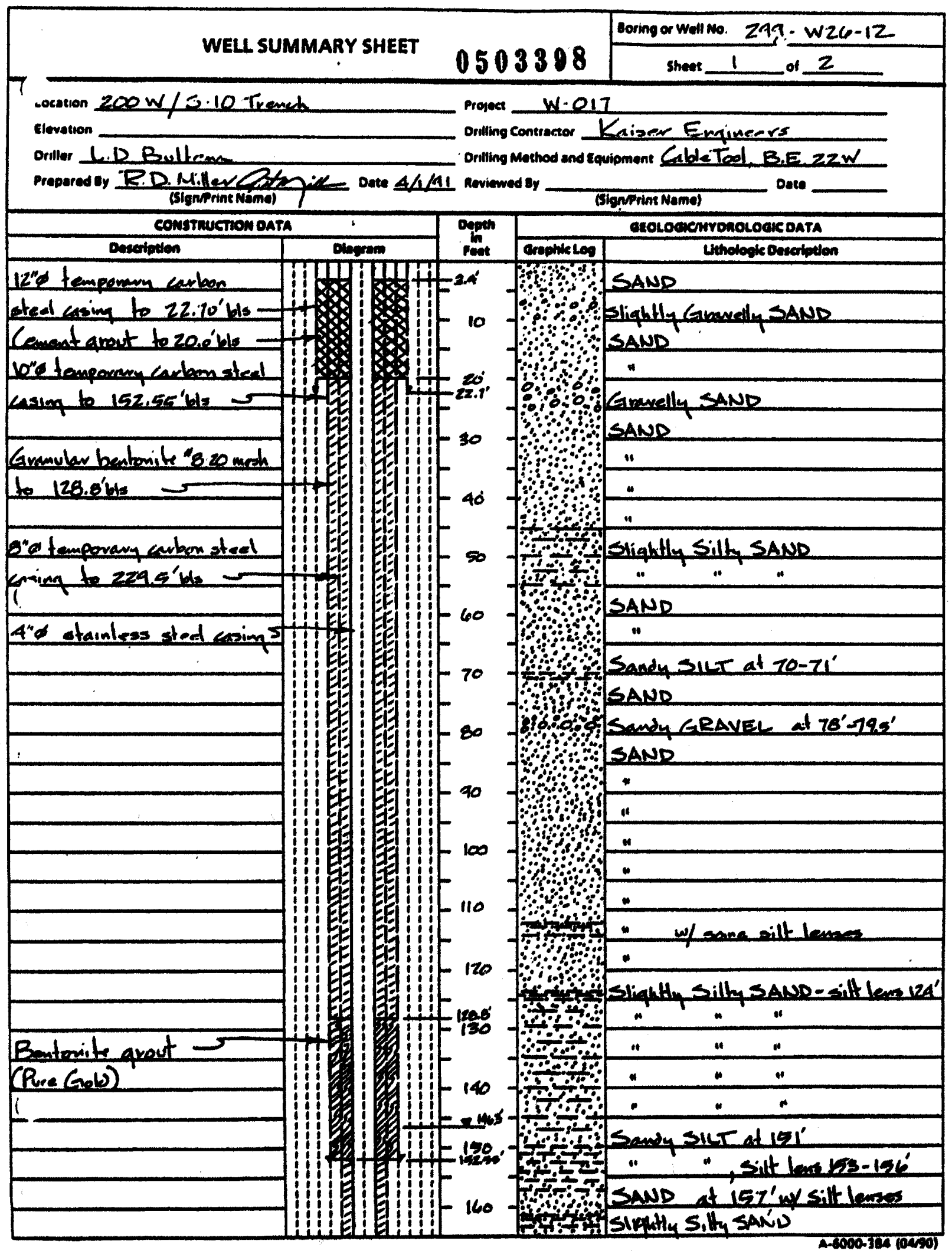




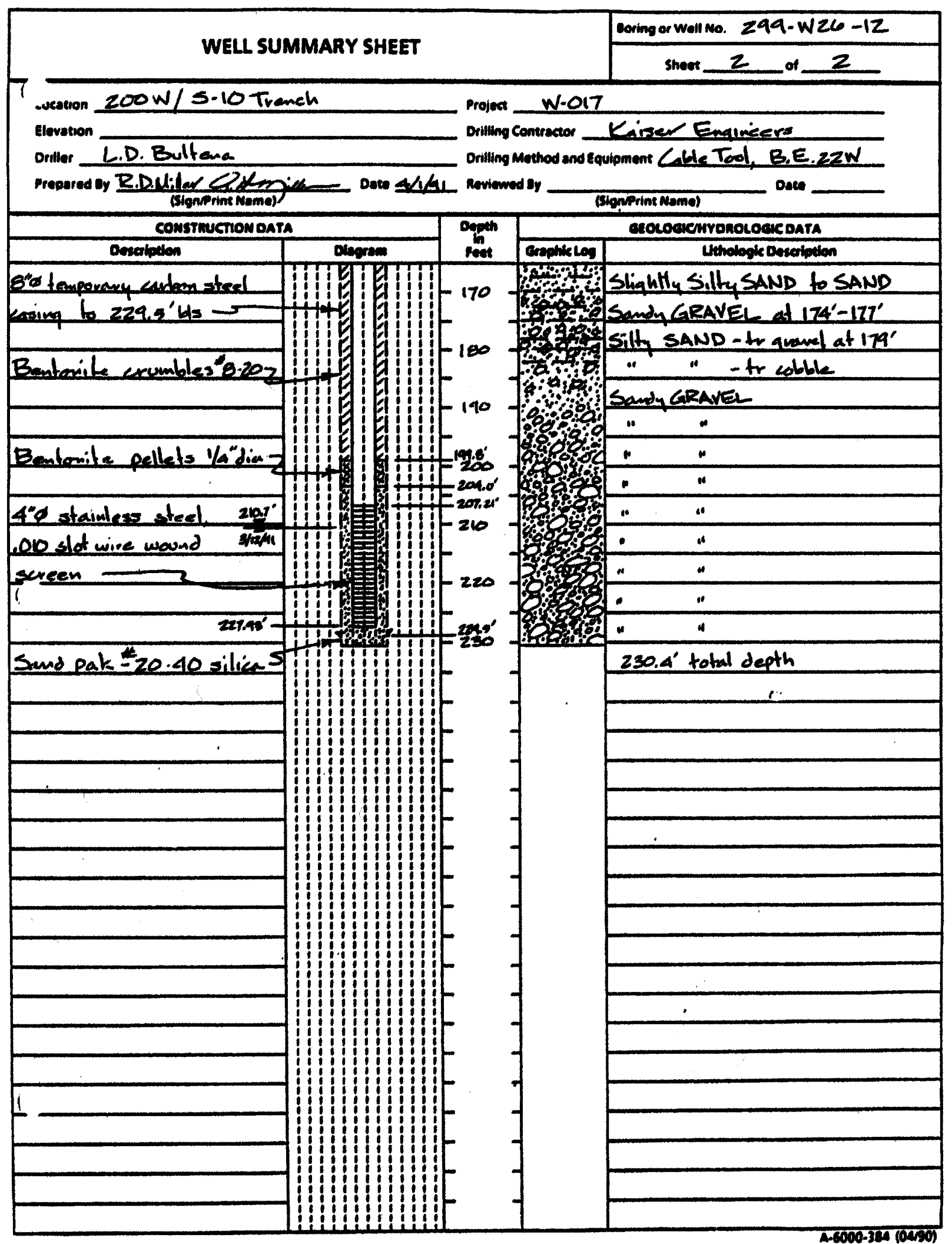


0515345

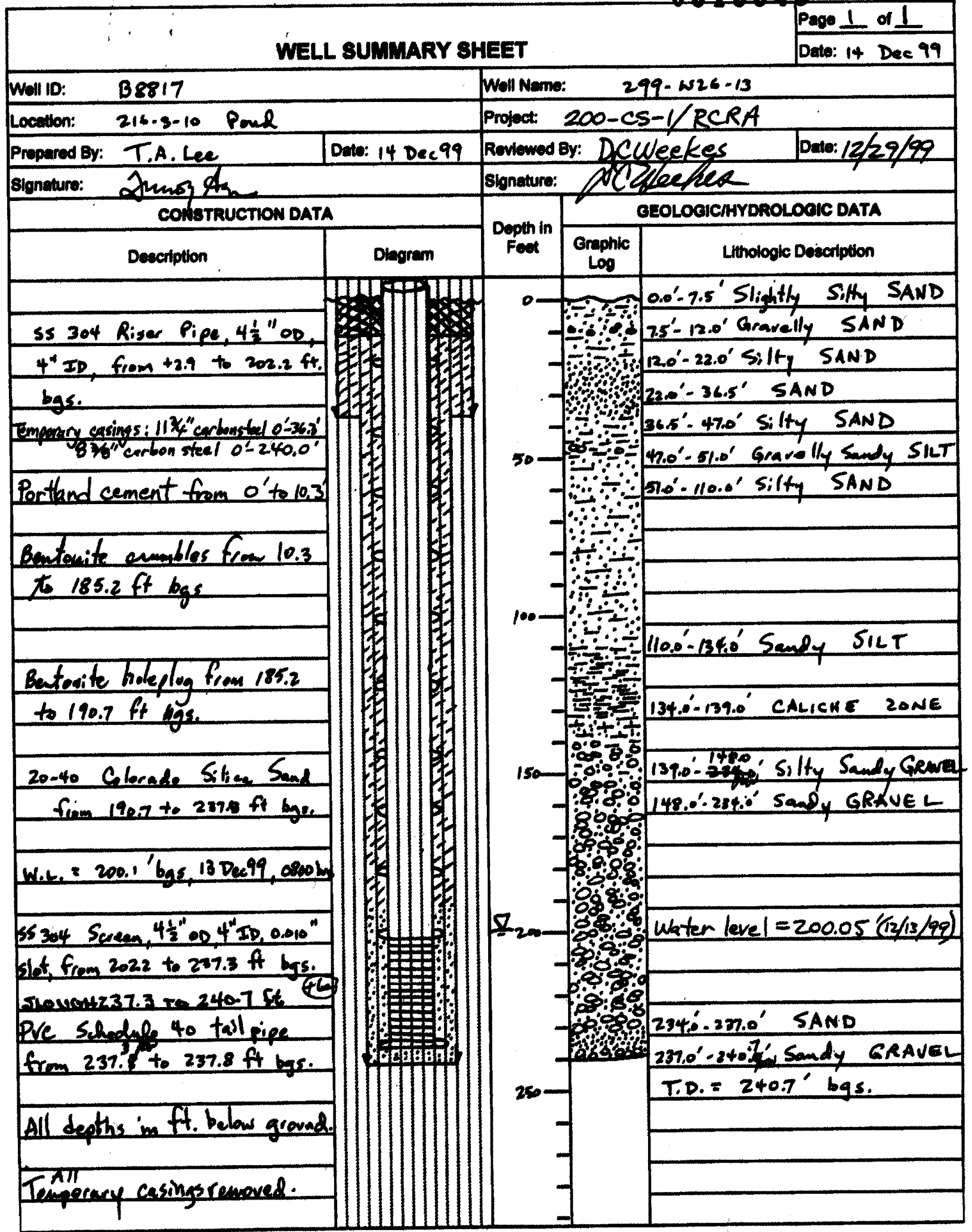




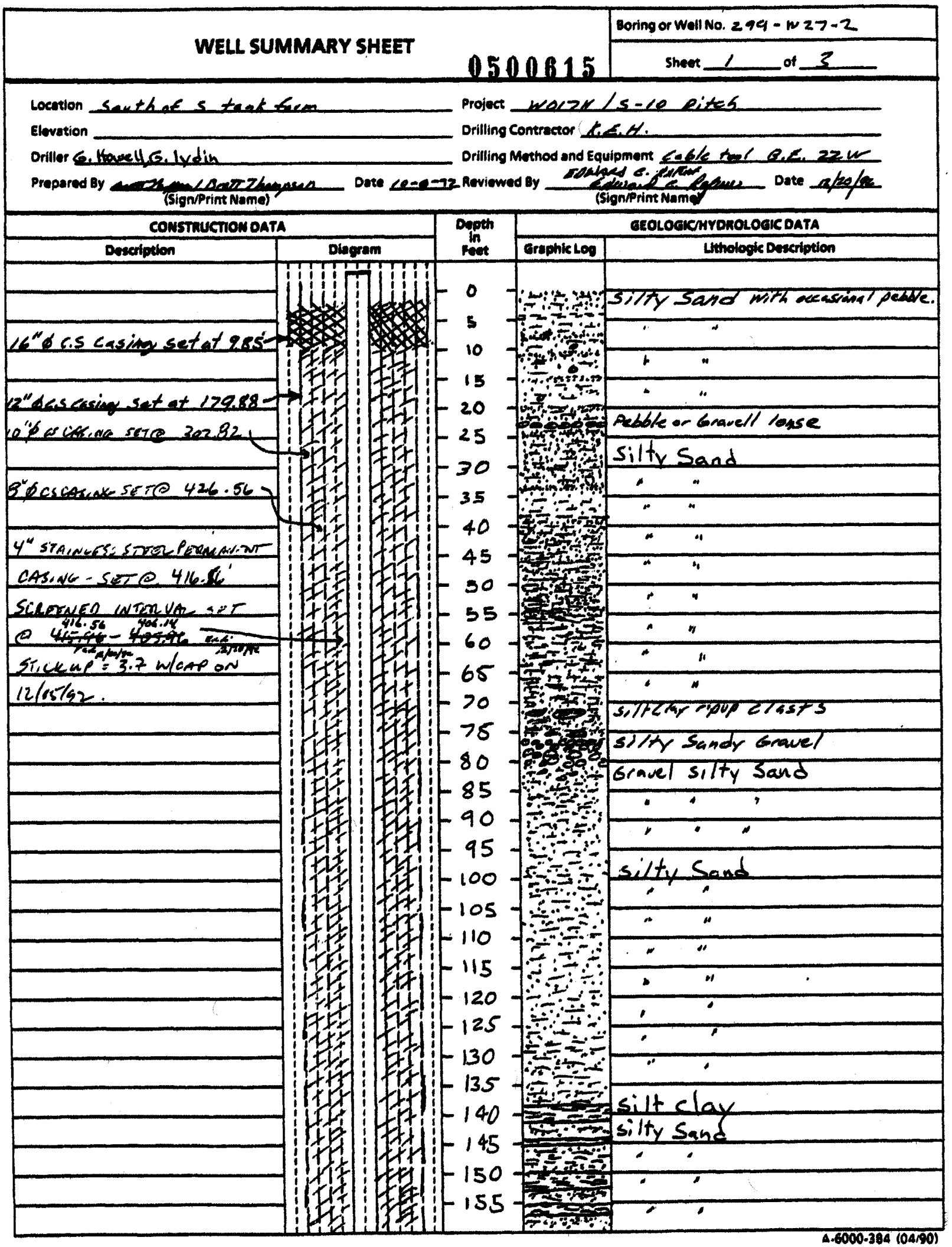




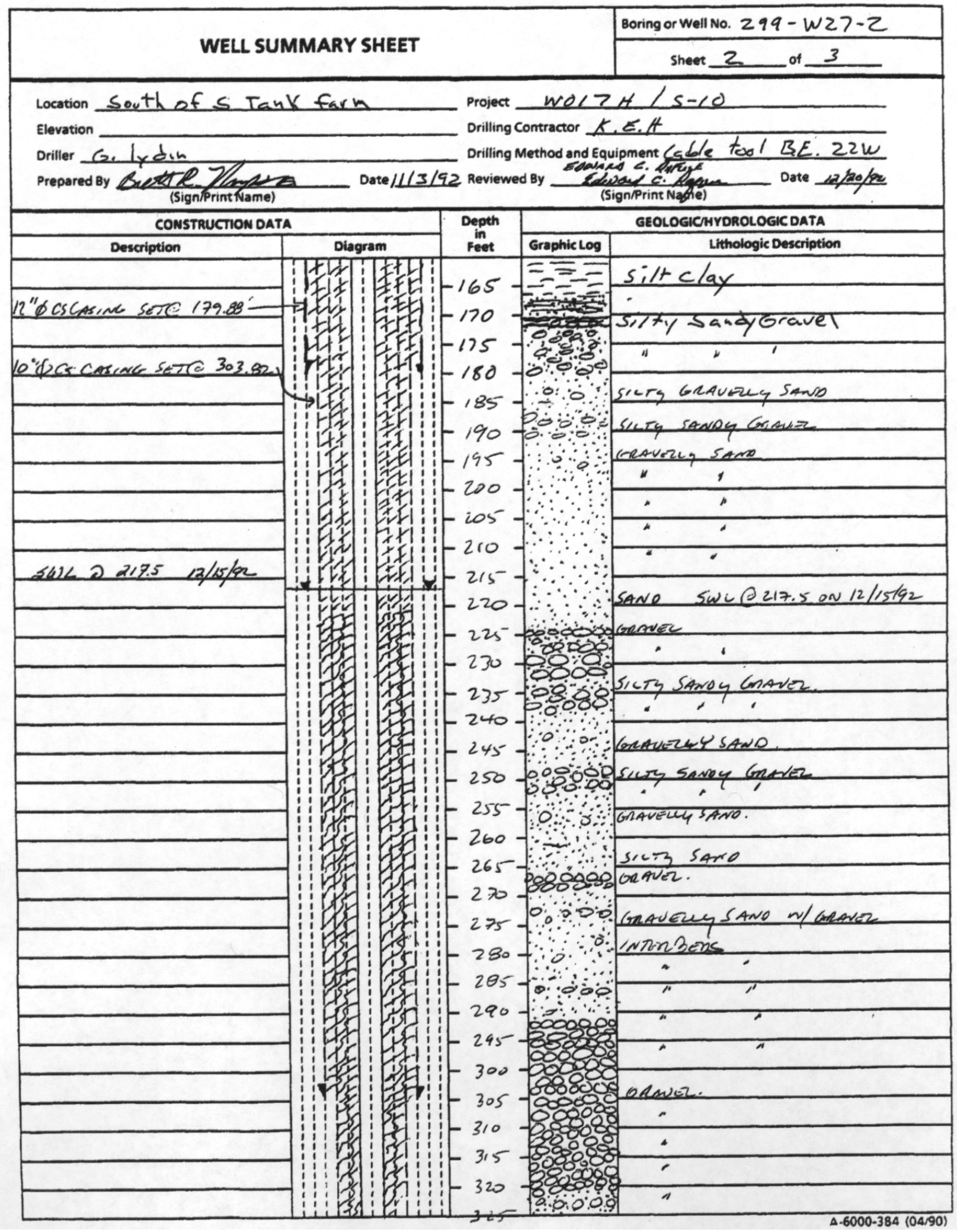

A. 13 


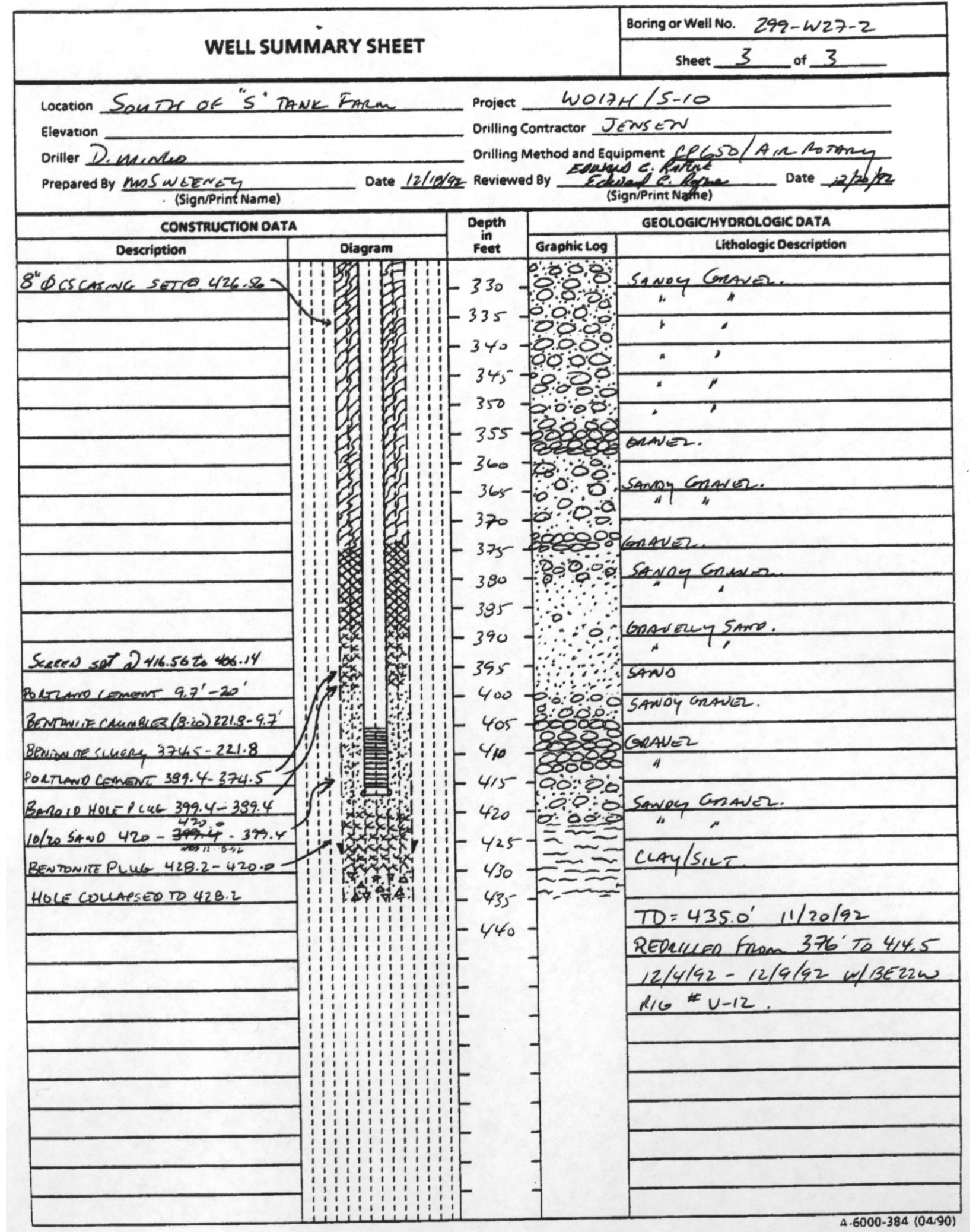




\section{Distribution}

No. of

Copies

ONSITE

6 DOE Richland Operations Office

M. J. Furman (2)

Administrative Record (2)

Public Reading Room (2)

2 Fluor Hanford Inc.

J. V. Borghese

E6-35

C. S. Cearlock

3 Washington Department of Ecology

D. Goswami

B5-18

J. A. Hedges

B5-18

A. D. Huckaby

E6-35

B5-18
No. of

Copies

11 Pacific Northwest National Laboratory

$\begin{array}{lr}\text { C. J. Chou } & \text { K6-81 } \\ \text { M. J. Hartman } & \text { K6-96 } \\ \text { V. G. Johnson } & \text { K6-96 } \\ \text { S. P. Luttrell } & \text { K6-96 } \\ \text { W. J. Martin } & \text { K6-81 } \\ \text { D. Vela } & \text { K6-96 } \\ \text { B. A. Williams (3) } & \text { K6-81 } \\ \text { Hanford Technical Library (2) } & \text { P8-55 }\end{array}$

Distr.1 